Prepared in cooperation with the Bureau of Land Management

Hydrologic and Water-Quality Responses in Shallow Ground Water Receiving Stormwater Runoff and Potential Transport of Contaminants to Lake Tahoe, California and Nevada, 2005-07

Scientific Investigations Report 2008-5162

Version 1.1, December 2008 
Cover: Lake Tahoe near Sand Harbor, Nevada. (Photograph taken by Arun Pudipeddi, September 2007.) 


\section{Hydrologic and Water-Quality Responses in Shallow Ground Water Receiving Stormwater Runoff and Potential Transport of Contaminants to Lake Tahoe, California and Nevada, 2005-07}

By Jena M. Green, Carl E. Thodal, and Toby L. Welborn

Prepared in cooperation with the Bureau of Land Management

Scientific Investigations Report 2008-5162

Version 1.1, December 2008 


\section{U.S. Department of the Interior DIRK KEMPTHORNE, Secretary}

\section{U.S. Geological Survey \\ Mark D. Myers, Director}

\section{U.S. Geological Survey, Reston, Virginia: 2008}

For product and ordering information:

World Wide Web: http://www.usgs.gov/pubprod

Telephone: 1-888-ASK-USGS

For more information on the USGS--the Federal source for science about the Earth, its natural and living resources, natural hazards, and the environment:

World Wide Web: http://www.usgs.gov

Telephone: 1-888-ASK-USGS

Any use of trade, product, or firm names is for descriptive purposes only and does not imply endorsement by the U.S. Government.

Although this report is in the public domain, permission must be secured from the individual copyright owners to reproduce any copyrighted materials contained within this report.

Suggested citation:

Green, J.M., Thodal, C.E., and Welborn, T.L., 2008, Hydrologic and water-quality responses in shallow ground water receiving stormwater runoff and potential transport of contaminants to Lake Tahoe, California and Nevada, 2005-07: U.S. Geological Survey Scientific Investigations Report 2008-5162, 64 p. 


\section{Contents}

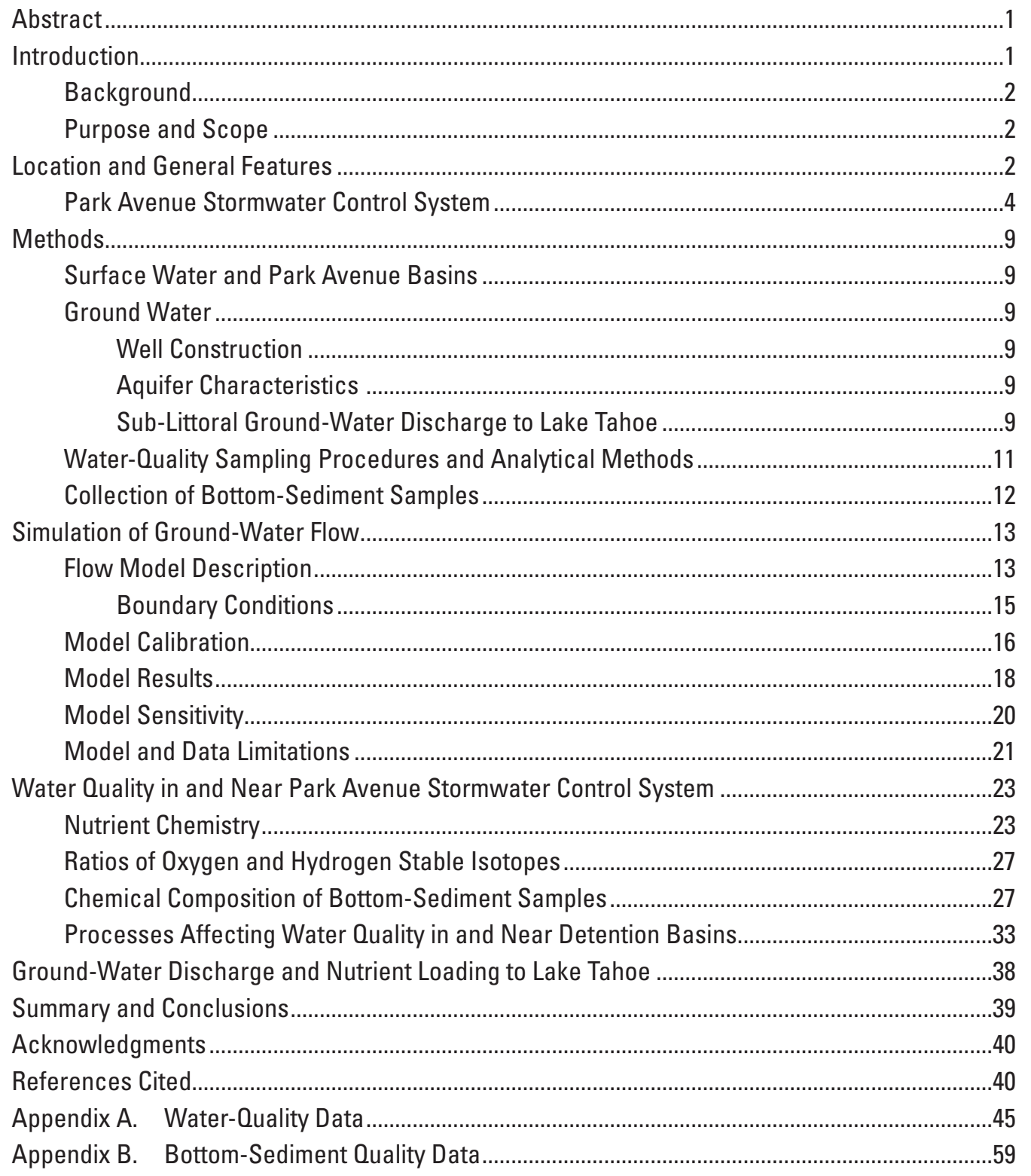




\section{Figures}

Figure 1. Map showing location of study area, South Lake Tahoe, California and Nevada ... 3

Figure 2. Map showing generalized geology of study area, South Lake Tahoe, California and Nevada

Figure 3. Map showing location of data collection sites, South Lake Tahoe, California and Nevada

Figure 4. Map showing detention basin bathymetry diagrams and site information, Park Avenue detention basins, South Lake Tahoe, California

Figure 5. Map showing layer 1 boundary conditions in steady-state ground-water flow model, South Lake Tahoe, California and Nevada

Figure 6. Diagram showing cross section of the modeled area along row 71, South Lake Tahoe, California and Nevada

Figure 7. Map showing upgradient watersheds used to calculate mountain-front recharge, South Lake Tahoe, California and Nevada

Figure 8. Graph showing measured water levels compared with model-simulated water levels, South Lake Tahoe, California and Nevada

Figure 9. Map showing calibrated model simulated water-level contours, monitoring well residuals (simulated-average observed values), and simulated annual ground-water discharge to South Lake Tahoe, California and Nevada

Figure 10. Diagram showing estimated ground-water budget for model area, South Lake Tahoe, California and Nevada 21

Figure 11. Graph showing relative sensitivity of model parameters 22

Figure 12. Boxplots showing statistical distribution of nitrogen and phosphorus concentrations in water samples grouped by source, Park Avenue detention basin, South Lake Tahoe, California

Figure 13. Graphs showing relations among net change in the volume of stormwater accumulated in PA1, precipitation, and unfiltered concentrations of nitrogen and phosphorus in sampled stormwater inflow, Park Avenue detention basin, South Lake Tahoe, California

Figure 14. Graphs showing relations among filtered concentrations of (A) nitrogen and (B) phosphorus and water-level changes in Park Avenue detention basin and nearby observation wells, South Lake Tahoe, California and Nevada

Figure 15. Graphs showing relation between stable isotopes of hydrogen and oxygen in lake-water and ground-water samples collected near Park Avenue stormwater collection system, South Lake Tahoe California, 2005-07

Figure 16. Pie charts showing relative contribution of nutrient species that constitute mean concentrations of nitrogen and phosphorus, South Lake Tahoe, 


\section{Tables}

Table 1. Information regarding data-collection sites used to investigate responses of shallow ground water receiving stormwater runoff from Park Avenue stormwater control system, South Lake Tahoe, California, 2005-07

Table 2. Estimated results of monitoring well slug tests near Park Avenue stormwater control system, South Lake Tahoe, California

Table 3. Constituents determined in water and sediment samples and laboratory reporting levels

Table 4. Polycyclic aromatic hydrocarbon compounds determined in bottom-sediment samples collected from stormwater control basin, site PA1, South Lake Tahoe, California, and laboratory reporting levels....

Table 5. Model parameters and their calibrated values, in order of sensitivity for original model, South Lake Tahoe, California and Nevada

Table 6. Statistical summary of nitrogen and phosphorus concentrations in water samples grouped by source, Park Avenue stormwater collection and detention system, South Lake Tahoe, California, water years 2006-07

Table 7. Concentrations of selected chemicals of potential concern in bottom sediment collected on August 31, 2005 from Park Avenue detention basin 1, South Lake Tahoe, California, and sediment toxicity screening values for protection of benthic aquatic life 


\section{Conversion Factors, Datums, and Water-Quality Abbreviations}

\section{Conversion Factors}

\begin{tabular}{|c|c|c|}
\hline Multiply & By & To obtain \\
\hline \multicolumn{3}{|c|}{ Length } \\
\hline inch (in.) & 2.54 & centimeter $(\mathrm{cm})$ \\
\hline foot $(\mathrm{ft})$ & 0.3048 & meter $(\mathrm{m})$ \\
\hline mile (mi) & 1.609 & kilometer $(\mathrm{km})$ \\
\hline \multicolumn{3}{|c|}{ Area } \\
\hline acre & 4,047 & square meter $\left(\mathrm{m}^{2}\right)$ \\
\hline$\underline{\text { square mile }\left(\mathrm{mi}^{2}\right)}$ & 2.590 & square kilometer $\left(\mathrm{km}^{2}\right)$ \\
\hline \multicolumn{3}{|c|}{ Volume } \\
\hline gallon (gal) & 3.785 & liter $(\mathrm{L})$ \\
\hline \multicolumn{3}{|c|}{ Flow rate } \\
\hline acre-foot per year (acre-ft/yr) & 1,233 & cubic meter per year $\left(\mathrm{m}^{3} / \mathrm{yr}\right)$ \\
\hline cubic foot per day $\left(\mathrm{ft}^{3} / \mathrm{d}\right)$ & 0.028 & cubic meter per day $\left(\mathrm{m}^{3} / \mathrm{d}\right)$ \\
\hline \multicolumn{3}{|c|}{ Mass } \\
\hline pound, avoirdupois (lb) & 0.4536 & kilogram (kg) \\
\hline \multicolumn{3}{|c|}{ Hydraulic conductivity } \\
\hline foot per day $(\mathrm{ft} / \mathrm{d})$ & 0.3048 & meter per day $(\mathrm{m} / \mathrm{d})$ \\
\hline \multicolumn{3}{|c|}{ Hydraulic gradient } \\
\hline foot per foot $(\mathrm{ft} / \mathrm{ft})$ & 1 & meter per meter $(\mathrm{m} / \mathrm{m})$ \\
\hline foot per mile (ft/mi) & 0.1894 & meter per kilometer $(\mathrm{m} / \mathrm{km})$ \\
\hline \multicolumn{3}{|c|}{ Transmissivity* } \\
\hline foot squared per day $\left(\mathrm{ft}^{2} / \mathrm{d}\right)$ & 0.09290 & meter squared per day $\left(\mathrm{m}^{2} / \mathrm{d}\right)$ \\
\hline
\end{tabular}

Temperature in degrees Celsius $\left({ }^{\circ} \mathrm{C}\right)$ may be converted to degrees Fahrenheit $\left({ }^{\circ} \mathrm{F}\right)$ as follows:

$$
{ }^{\circ} \mathrm{F}=\left(1.8 x^{\circ} \mathrm{C}\right)+32
$$

Temperature in degrees Fahrenheit $\left({ }^{\circ} \mathrm{F}\right)$ may be converted to degrees Celsius $\left({ }^{\circ} \mathrm{C}\right)$ as follows:

$$
{ }^{\circ} \mathrm{C}=\left({ }^{\circ} \mathrm{F}-32\right) / 1.8
$$

*Transmissivity: The standard unit for transmissivity is cubic foot per day per square foot times foot of aquifer thickness $\left[\left(\mathrm{ft}^{3} / \mathrm{d}\right) / \mathrm{ft}^{2}\right] \mathrm{ft}$. In this report, the mathematically reduced form, foot squared per day $(\mathrm{ft} 2 / \mathrm{d})$, is used for convenience.

Specific conductance is given in microsiemens per centimeter at 25 degrees Celsius $\left(\mu \mathrm{S} / \mathrm{cm}\right.$ at $\left.25^{\circ} \mathrm{C}\right)$.

Concentrations of chemical constituents in water are given either in milligrams per liter (mg/L) or micrograms per liter $(\mu \mathrm{g} / \mathrm{L})$.

Datums

Vertical coordinate information is referenced to the North American Vertical Datum of 1988 (NAVD 88). Horizontal coordinate information is referenced to the North American Datum of 1983 (NAD 83). Altitude, as used in this report, refers to distance above the vertical datum.

Water-Quality Abbreviations

\begin{tabular}{ll}
\hline Abbreviations & Definitions \\
\hline $\mathrm{g}$ & gram \\
$\mu \mathrm{g} / \mathrm{g}$ & microgram per gram \\
$\mu \mathrm{g} / \mathrm{kg}$ & microgram per kilogram \\
$\mu \mathrm{g} / \mathrm{L}$ & microgram per liter \\
$\mathrm{mg} / \mathrm{L}$ & milligram per liter \\
$\mathrm{mL}$ & milliliter \\
\hline
\end{tabular}




\title{
Hydrologic and Water-Quality Responses in Shallow Ground Water Receiving Stormwater Runoff and Potential Transport of Contaminants to Lake Tahoe, California and Nevada, 2005-07
}

\author{
By Jena M. Green, Carl E. Thodal, and Toby L. Welborn
}

\section{Abstract}

Clarity of Lake Tahoe, California and Nevada has been decreasing due to inflows of sediment and nutrients associated with stormwater runoff. Detention basins are considered effective best management practices for mitigation of suspended sediment and nutrients associated with runoff, but effects of infiltrated stormwater on shallow ground water are not known. This report documents 2005-07 hydrogeologic conditions in a shallow aquifer and associated interactions between a stormwater-control system with nearby Lake Tahoe. Selected chemical qualities of stormwater, bottom sediment from a stormwater detention basin, ground water, and nearshore lake and interstitial water are characterized and coupled with results of a three-dimensional, finite-difference, mathematical model to evaluate responses of ground-water flow to stormwater-runoff accumulation in the stormwatercontrol system.

The results of the ground-water flow model indicate mean ground-water discharge of 256 acre feet per year, contributing 27 pounds of phosphorus and 765 pounds of nitrogen to Lake Tahoe within the modeled area. Only 0.24 percent of this volume and nutrient load is attributed to stormwater infiltration from the detention basin.

Settling of suspended nutrients and sediment, biological assimilation of dissolved nutrients, and sorption and detention of chemicals of potential concern in bottom sediment are the primary stormwater treatments achieved by the detention basins. Mean concentrations of unfiltered nitrogen and phosphorus in inflow stormwater samples compared to outflow samples show that 55 percent of nitrogen and 47 percent of phosphorus are trapped by the detention basin. Organic carbon, cadmium, copper, lead, mercury, nickel, phosphorus, and zinc in the uppermost 0.2 foot of bottom sediment from the detention basin were all at least twice as concentrated compared to sediment collected from 1.5 feet deeper. Similarly, concentrations of 28 polycyclic aromatic hydrocarbon compounds were all less than laboratory reporting limits in the deeper sediment sample, but 15 compounds were detected in the uppermost 0.2 foot of sediment. Published concentrations determined to affect benthic aquatic life also were exceeded for copper, zinc, benz[a]anthracene, phenanthrene, and pyrene in the shallow sediment sample.

Isotopic composition of water (oxygen 18/16 and hydrogen 2/1 ratios) for samples of shallow ground water, lakewater, and interstitial water from Lake Tahoe indicate the lake was well mixed with a slight ground-water signature in samples collected near the lakebed. One interstitial sample from 0.8 foot beneath the lakebed was nearly all ground water and concentrations of nitrogen and phosphorus were comparable to concentrations in shallow ground-water samples. However, ammonium represented 65 percent of filtered nitrogen in this interstitial sample, but only 10 percent of the average nitrogen in ground-water samples. Nitrate was less than reporting limits in interstitial water, compared with mean nitrate concentration of 750 micrograms per liter in ground-water samples, indicating either active dissimilative nitrate reduction to ammonium by micro-organisms or hydrolysis of organic nitrogen to ammonium with concomitant nitrate reduction. The other interstitial sample falls along a mixing line between ground water and lake water and most of the nitrogen was organic nitrogen.

\section{Introduction}

Lake Tahoe, an approximately $191 \mathrm{mi}^{2}$ lake along the state line between western Nevada and eastern California, is a natural resource known for its deep, clear water. Protection of its renowned clarity has become important in the past half century, as clarity has been decreasing by about $1 \mathrm{ft}$ each year (Goldman, 2000). Decreased clarity has been attributed to human activities that increase nutrient and sediment inputs to the lake (Goldman, 1988). In spite of numerous projects implemented to mitigate decreasing clarity, including 
Hydraulic and Water-Quality Responses in Shallow Ground Water, Lake Tahoe, California and Nevada, 2005-07

exportation of all waste-water effluent and erosion-control regulations, lake clarity has continued to decline (Goldman, 2000). Nutrients enter the lake from streams, atmospheric deposition, erosion of shorelines and intervening areas, and by ground-water inflow (Reuter and others, 1998; Reuter and Miller, 2000). Estimates of nutrient inputs to Lake Tahoe by ground water have been made using regionalized values of hydraulic properties coupled with averaged nutrient concentrations (Thodal, 1997; U.S. Army Corps of Engineers, 2003). Several nearshore areas of Lake Tahoe have been identified as having increased turbidity and algal production that consistently are elevated compared to the midlake. Although atmospheric deposition of nitrogen is estimated to contribute most of the nutrient loading to the lake and may be responsible for overall decline of lake clarity, nearshore clarity losses may be caused by local influences, including nutrientenriched ground-water discharge (Taylor, 2002).

Collection, detention, and infiltration of stormwater runoff in constructed basins is considered an effective best management practice (BMP) for achieving water-quality criteria related to total maximum daily load regulations (Schuster and Grismer, 2004). However, while this type of BMP may mitigate surface-water loads of suspended sediment to the lake, infiltrated stormwater in the detention basin may contaminate shallow ground water and increase ground-water gradients and flow to the lake. In addition, contaminants associated with stormwater runoff often include organic compounds and metals that potentially are toxic when consumed. Processes that affect ground-water contamination from stormwater have only just begun to be considered (Thomas and others, 2004; Prudic and others, 2005; Green, 2006), but understanding these processes is important because growing numbers of environmental improvement program projects are planned to encourage infiltration of stormwater runoff.

\section{Background}

Past detention-basin studies have focused more on suspended-sediment reductions than nutrient reductions. Martin (1988) experimented with routing flow through a detention basin and wetlands in series and found that while suspended-sediment loads were reduced, nutrient-load reductions were variable. The efficiency rates were between 0 and 72 percent (Martin, 1988), depending on the type of nutrient, the detention basin, and wetlands. Similarly, Reuter and others (1992) routed flow through a wet meadow and found a reduction in suspended solids but little change in nutrient concentrations. Ground water underlying detention basins near Lake Tahoe may have increased water-quality degradation because much of the stormwater runoff occurs during snowmelt, when vegetation is dormant and not assimilating nutrients (Prudic and others, 2005).

\section{Purpose and Scope}

This report documents 2005-07 hydrogeologic conditions in a shallow ground-water flow system adjacent to Lake Tahoe and the effects of an engineered stormwater-control system. Descriptions of the basin-fill aquifer and a stormwater collection and control system; quantification of components of the ground-water budget; and characteristics of the quality of stormwater, bottom sediment from a stormwater detention basin, ground water, and nearshore lake and interstitial water are included. Results of a three-dimensional, finite-difference, ground-water flow model also are presented as a tool to evaluate responses of ground-water flow to stormwater runoff accumulation in the stormwater-control system.

The city of South Lake Tahoe hired 2NDNATURE, LLC, in June 2005, to "design and implement a two year datacollection program to promote a quantitative understanding of the impacts of urban surface water infiltration via stormwatertreatment systems on the quality of shallow groundwater resources” (Maggie Mathias, 2NDNATURE, LLC, written commun., September 2006), which provided the opportunity for collaboration and data sharing. Ground-water flow and seepage across the lake interface was simulated by the U.S. Geological Survey (USGS).

\section{Location and General Features}

The study area is in the Lake Tahoe basin, along the California-Nevada state line. It coincides with a $2.91 \mathrm{mi}^{2}$ intervening area, delineated topographically as an area that is tributary to Lake Tahoe without a perennial stream draining into the lake (site 69; Jorgensen and others, 1978). The area is bounded by the drainage basins of Bijou and Heavenly Valley creeks in California, by Edgewood Creek Basin in Nevada, and by about 8,000 ft of Lake Tahoe shoreline (fig. 1). The area's land surface slopes steeply (0.46 ft/ft) from the ridge northwest of Heavenly Valley Creek to the consolidated rock-alluvium contact at 6,350 ft. Land surfaces slope more gradually (about $0.03 \mathrm{ft} / \mathrm{ft}$ ) from that contact to the legally defined minimum lake stage altitude of $6,223 \mathrm{ft}$ above sea level. The nearshore lakebed slopes more gradually $(0.015 \mathrm{ft} / \mathrm{ft})$ to about $0.75 \mathrm{mi}$ offshore, before plunging steeply $(0.11 \mathrm{ft} / \mathrm{ft})$ to the $600 \mathrm{ft}$ depth contour about $1.5 \mathrm{mi}$ offshore.

Consolidated rocks in the study area are light-gray, fine- to medium-grained, well foliated granitic type rocks of Cretaceous age (about 90 million years ago; Armin and John 1983; Bonham and Burnett, 1976; Saucedo, 2005). These consolidated rocks have little porosity and generally are impermeable to ground-water flow, except where fractured or weathered. Unconsolidated basin-fill deposits are weathered mostly from consolidated granitic rocks and sorted to varying degrees by fluvial processes. During the Pleistocene Epoch, 


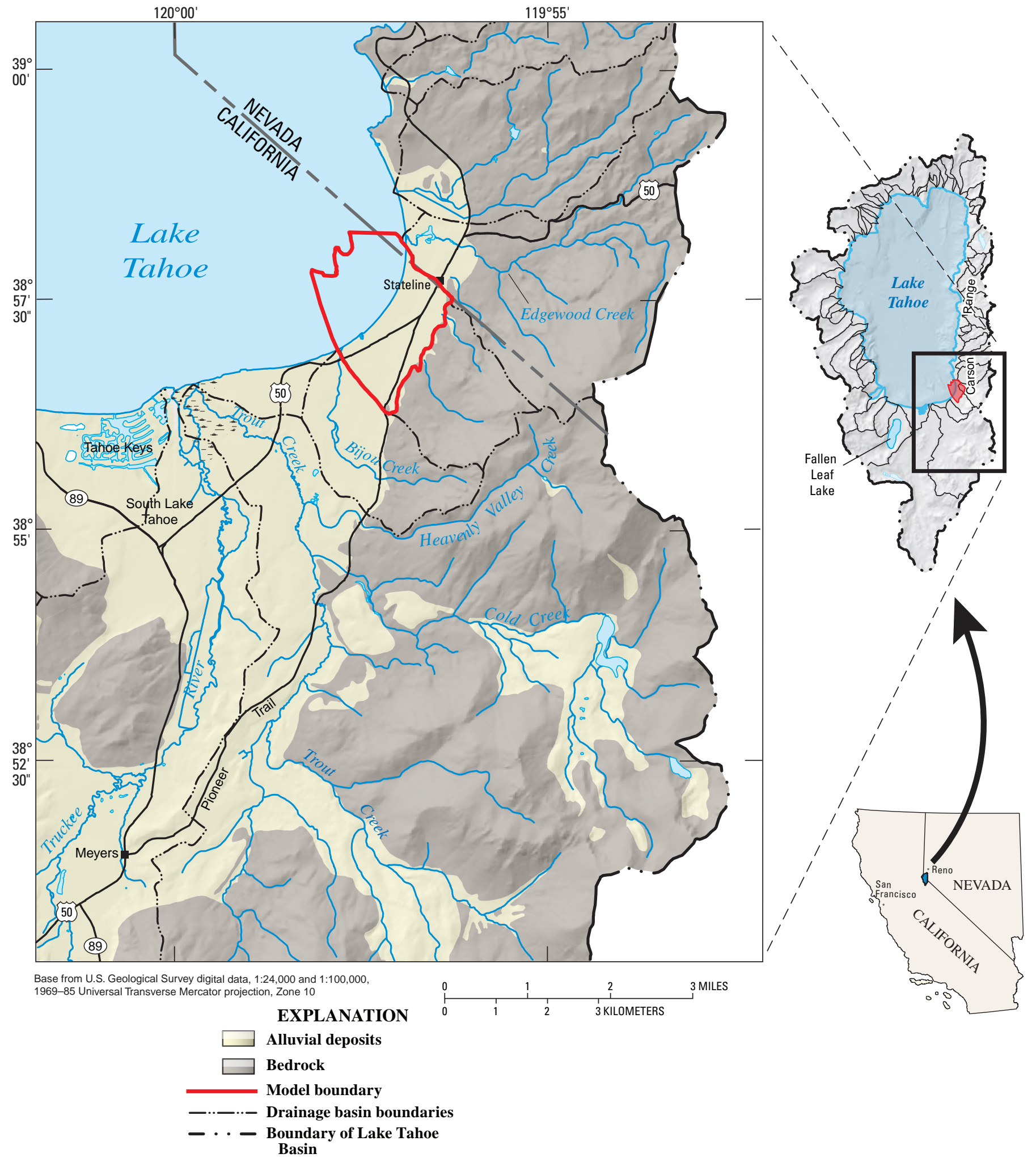

Figure 1. Location of study area, South Lake Tahoe, California and Nevada. 
Hydraulic and Water-Quality Responses in Shallow Ground Water, Lake Tahoe, California and Nevada, 2005-07

glaciers dammed outflow from Lake Tahoe resulting in formation of lacustrine deposits of moderately to poorly sorted silt, sand, and gravel that accumulated as broad terraces 15-30 ft above current lake levels. Pleistocene beach deposits are gravelly, coarse arkosic sand that have been moderately sorted by wave action during higher lake levels. Younger (Recent Holocene) beach deposits are moderately sorted fineto very coarse-grained sand to gravelly arkosic sand coincident with modern lake levels. A small, manmade deposit of varying composition was imported for construction of the casinos and associated development along the state line. Two narrow bands of alluvium have been poorly to moderately sorted by intermittent streamflow from the area's upland areas. The distribution of these deposits is shown in figure 2.

The area between the lake and the consolidated-rock alluvium is urbanized (fig. 2). Development prior to about 1940 was limited to logging, agricultural, and fishing communities, and several roadhouses catering to transSierra travelers and those attracted to the health and pleasure attributes of Lake Tahoe. Tourism and recreation became increasingly important to the economy of the area, especially following World War II, and most of the area's manmade impervious surfaces were originally constructed between 1940 and 1969 (C.G. Raumann, U.S. Geological Survey, written commun., 2007). Along the Highway 50 corridor within the study area are several casinos in Nevada and numerous side streets with motels, shopping complexes, and residential developments that result in increased impervious land cover and stormwater runoff. The mountainous uplands of the area are forested with residential developments, motels, and shops catering primarily to Heavenly Valley Ski Resort. The city of South Lake Tahoe incorporated in November 1965, with a population of about 14,000 (Crippen and Pavelka, 1970, p. 26). According to the 2000 U.S. Census, the population of the city of South Lake Tahoe, California, was 23,609 and Stateline, Nevada, was 1,215.

Prior to a 1970 mandate to treat and export all domestic wastewater from the Lake Tahoe Basin, disposal practices had evolved from privies and wastewater cesspools and lagoons to septic tank-leachfield systems to land application of treated municipal effluent. These practices resulted in nitrogen contamination of the regional ground-water flow system that was reported in low-flow stream samples (Perkins and others, 1975) and in ground-water monitoring results (Thodal, 1997).

\section{Park Avenue Stormwater Control System}

Stormwater-drainage networks in South Lake Tahoe have developed in a piecemeal fashion since rain and snowmelt were diverted from unpaved wagon trails in the early 1900s. By May 2008, an estimated 1,500 drainage inlets collect stormwater from street and parking lot gutters in the city with 15 stormwater treatment vaults and 100 outfalls to surface waters that are tributary to Lake Tahoe (City of South Lake Tahoe, 2008, p. 6-29). The Federal Water Pollution Control
Act (also referred to as the Clean Water Act) was amended in 1987 to include controlling pollutants in stormwater runoff under the National Pollutant Discharge Elimination System. The U.S. Environmental Protection Agency promulgated regulation in 1990 to require separate municipal stormsewer systems serving a population of 100,000 or more to obtain stormwater permits. These regulations were amended in 1999 to require permits for stormwater discharges from small conveyance systems and from construction sites disturbing between 1 and 5 acres of land. The Lahontan Regional Water Quality Control Board adopted Order 6-92-02 in 1992 that requires stormwater permits for all municipal separate stormsewer systems (MS4s) on the California side of the Lake Tahoe basin. This permitting system provides a mechanism to work with the local municipalities to improve stormwatermanagement and maintenance practices, and requires permittees to develop comprehensive stormwater-management programs in the Lake Tahoe area (California Regional Water Quality Control Board, Lahontan Region, 2005).

Application for a stormwater permit typically requires one or more BMPs (methods that have been determined to be the most effective, practical means of preventing or reducing pollution from stormwater runoff). These practices may include behavioral BMPs such as education, structural BMPs such as source and treatment controls to treat runoff before it discharges to the storm drain or local waterways, and other practices that prevent or reduce pollutants from reaching the stormdrain or other waters (California Regional Water Quality Control Board, Lahontan Region, 2005, attachment A).

The Park Avenue stormwater control system is a BMP selected for investigation of ground water responses to infiltration of stormwater runoff. It is a structural treatment control that includes two detention basins near Park Avenue, in South Lake Tahoe, north of Highway 50 (fig. 3). The system is designed to collect runoff from a pre-existing urban stormwater-drainage network into detention basins that allow suspended sediment and associated nutrients to settle or be assimilated by vegetation, or infiltrate through soil to the shallow ground water. One detention basin (site PA1; fig. 4A) was constructed in 2000 and a second detention basin (site PA2; fig. 4B) was constructed in 2002. PA1 normally is a perennial wetland/shallow detention basin, with cattails, rushes, sedges, and duckweed (genera Typha, Juncus, Carex, and Scirpus, respectively) and a benthic periphyton community capable of assimilating biologically available nutrients. PA2 is a dry basin that receives stormwater only when inflow to PA1 exceeds the basin's capacity. Runoff from upgradient areas serviced by the stormdrain network flows into PA1 via two culverts (sites PA1_inletA and PA1_inletB; fig. 4A) and when PA1 reaches its capacity, overflows into a culvert (PA1_out) that conveys water to PA2 and into an open unlined ditch. A dam in the ditch can be operated manually to divert flow to a wet meadow in an adjacent neighborhood during excessive stormwater runoff. 


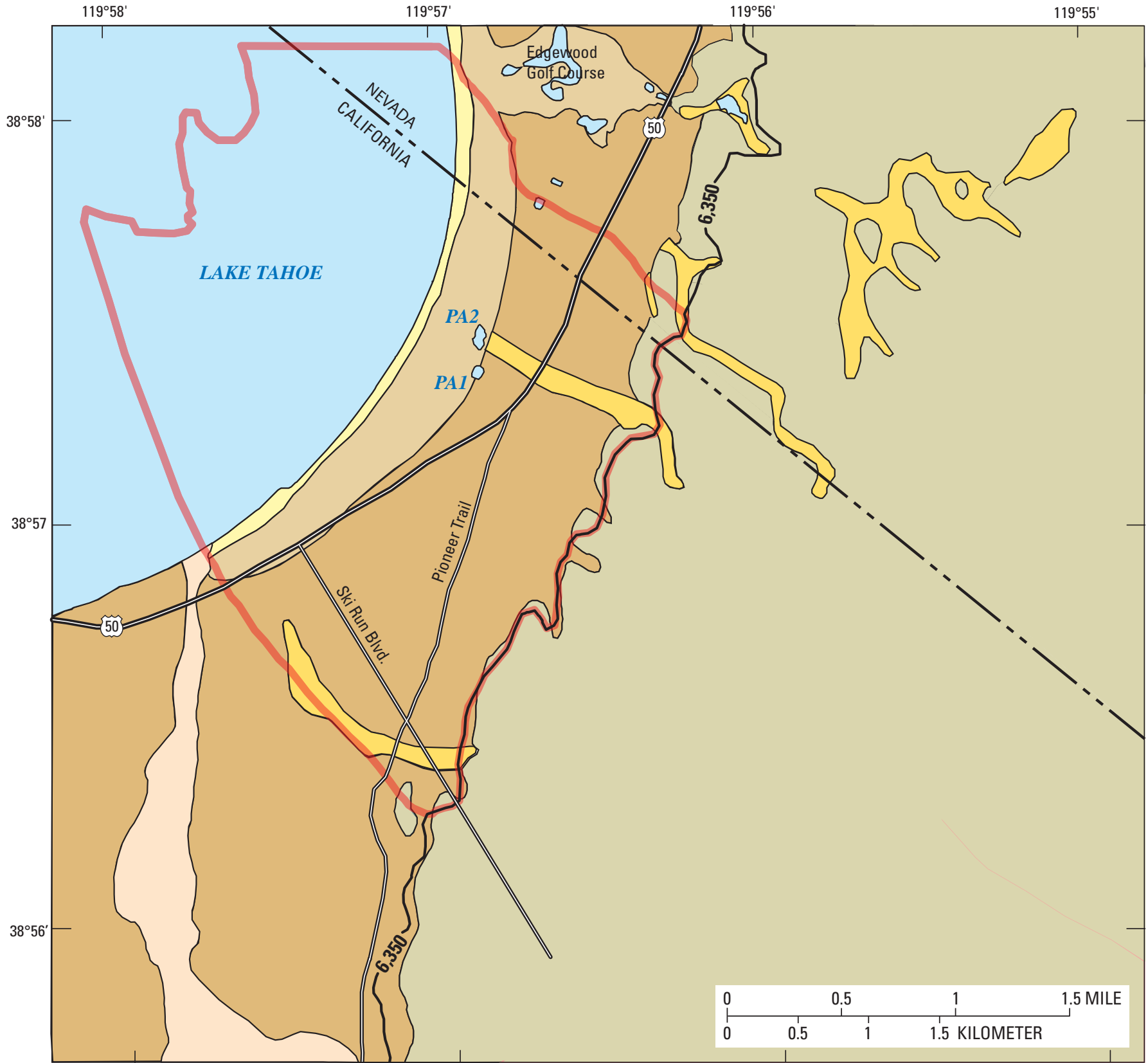

\section{EXPLANATION}

Younger beach deposits (Holocene) - Moderately sorted, fineto very coarse-grained to gravelly arkosic sand

Flood-plain deposits (Holocene) - Gravelly to silty sand and sandy to clayey silt. In part may be Pleistocene

Alluvium (Holocene and Pleistocene) - Unconsolidated, moderately to poorly sorted sand, silt and gravel
Older beach deposits (Pleistocene) — Moderately sorted gravelly, coarse arkosic sand

Lacustrine terrace deposits (Pleistocene) - Poorly to moderately sorted silt, sand, and gravel forming broad low terraces 15-30 feet above lake level

Consolidated rocks (Cretaceous) - Composition primarily granodiorite with adamellite, quartz diorite, quartz monzodiorite, and diorite. Forms the bedrock basement of the Lake Tahoe Basin

\footnotetext{
Model boundary - Coincident with 6,350 foot land-surface contour
}

Figure 2. Generalized geology of study area, South Lake Tahoe, California and Nevada. 


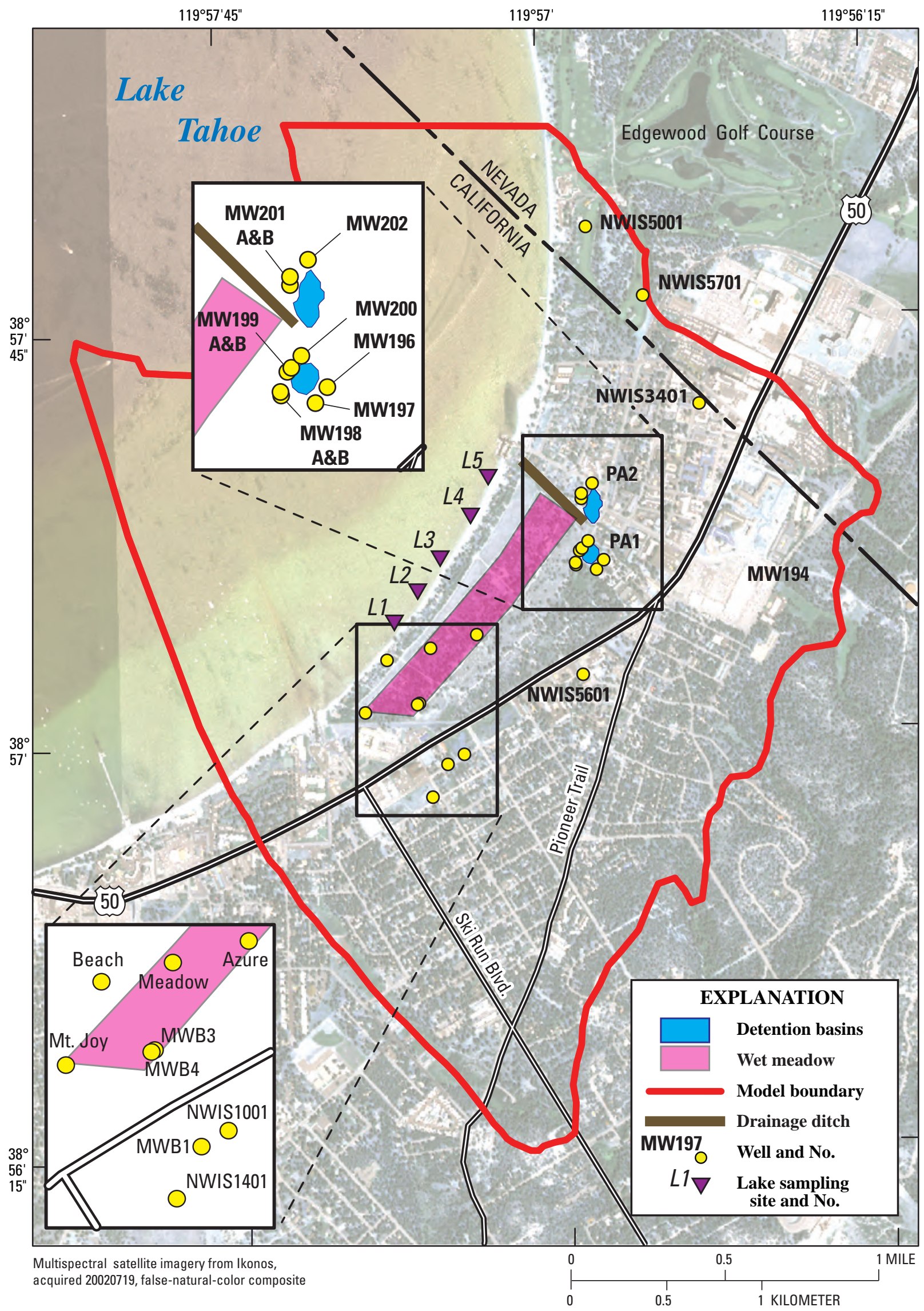

Figure 3. Location of data collection sites, South Lake Tahoe, California and Nevada. 


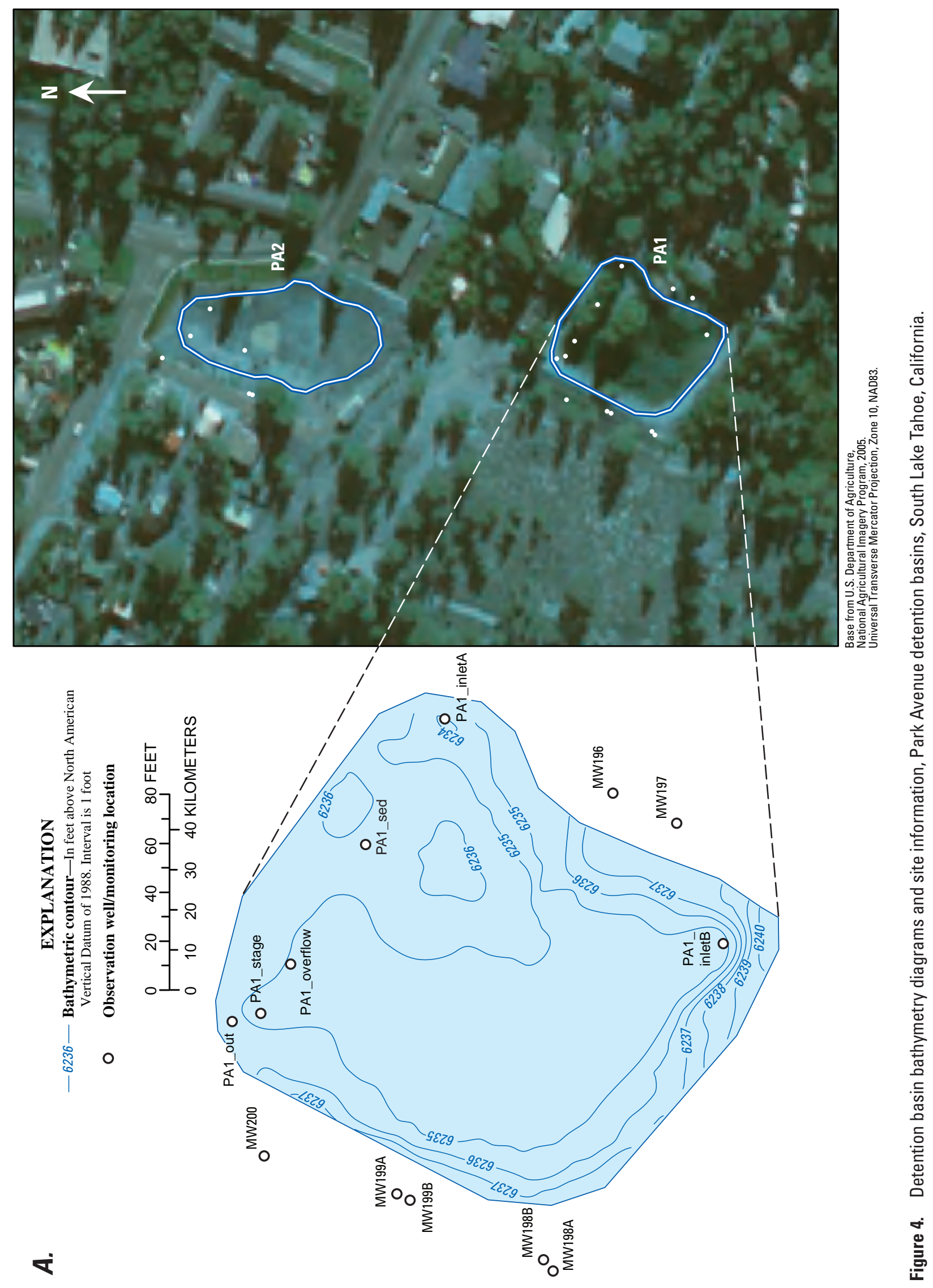




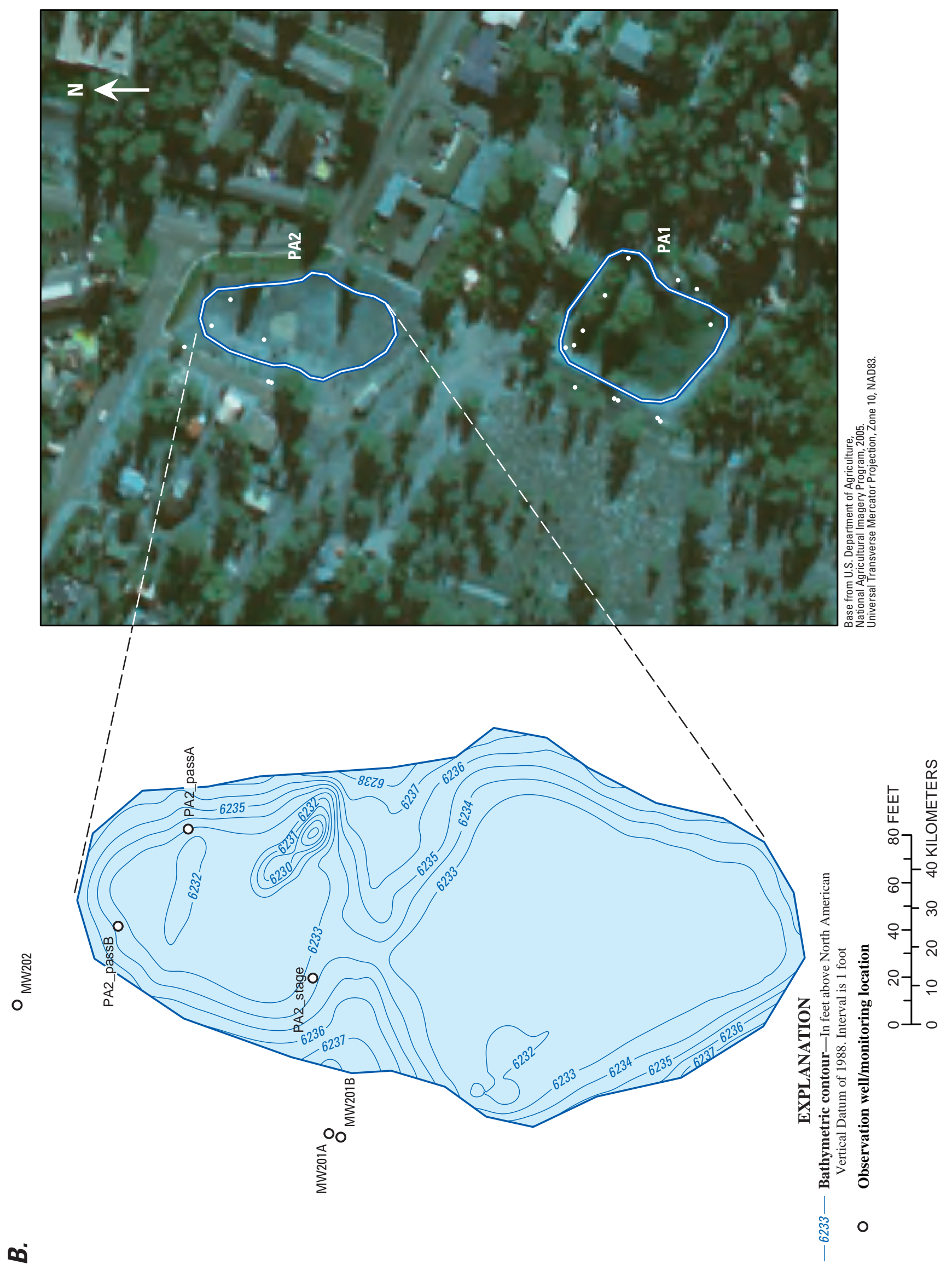

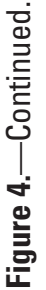




\section{Methods}

Data-collection sites used for this investigation are listed and described in table 1 and locations are shown in figure 3 . 2NDNATURE, LLC, purchased, installed, and maintained instrumentation used to monitor water-level changes in the detention basins and selected wells, and to monitor stormwater inflow. These data are presented courtesy of 2NDNATURE, LLC.

\section{Surface Water and Park Avenue Basins}

2NDNATURE, LLC, installed and maintained two recording pressure transducers and staff plates to monitor water stage in basins PA1 and PA2 and two flow-velocity meters and automated samplers (Sigma ${ }^{\circledR}$ ) in two culverts (sites PA1_inletA and PA1_inletB) that convey stormwater into PA1. A third pressure transducer was installed to correct nonvented transducers for changes in barometric pressure. The transducers recorded average pressure every 30 minutes that was converted to depth of water below the measuring point; the staff plates provided a visual check of the altitude of the water surface in each detention basin. USGS used a real-time kinematic Global Positioning System to survey locations and altitudes of each transducer to convert all data to a common datum and also surveyed the bathymetry of each detention basin (fig. 4). Elevation of the surface of Lake Tahoe was obtained from the water-stage recording gage that is operated by USGS (station number 10337000) on the U.S. Coast Guard pier on the north shore of Lake Tahoe. The datum of the gage is 6,220.00 ft above Bureau of Reclamation datum, which is 6,218.86 ft above the National Geodetic Vertical Datum of 1929. Lake elevations referred to Bureau of Reclamation datum because that datum is used as the official reference point by all Federal, State, and local agencies (available at http://waterdata.usgs.gov/nwisweb/local/state/ca/ text/10337000-manu.html).

\section{Ground Water}

\section{Well Construction}

Seven observation wells were installed during October and November 2005 to characterize local aquifer hydraulic properties, monitor ground-water levels, and to sample ground water (fig. 4). The wells also were used to evaluate responses of local ground water to infiltration of stormwater that accumulated in detention basins (PA1 and PA2). Boreholes used for well installation were drilled using a trailer-mounted hollow-stem auger that produced a borehole diameter of about 6.6 in. Wells were installed in boreholes drilled to depths of 14-30 ft below land surface and constructed of flush- thread, 2-in. nominal diameter ASTM 480-88A, schedule 40 polyvinyl chloride well casing, screens, and end points. Well screens (5 ft long with 0.020 in. factory slots) were positioned below the water table and surrounded with clean, coarse (\#6) aquarium gravel. Clean, fine (\#12) sand was used to fill the borehole to about $1 \mathrm{ft}$ above the water table and high-swelling 100 percent pure sodium bentonite (certified by the National Sanitation Foundation, International, to meet ANSI/NSF Standard 60; Drinking Water Treatment Chemicals-Health Effects) was emplaced from the top of the fine sand to $2 \mathrm{ft}$ beneath land surface to provide a sanitary seal. The top of well casings extend about $3 \mathrm{ft}$ above land surface to avoid inflow of surface water and a $0.3 \mathrm{ft}$ by $0.3 \mathrm{ft}$ locking well protector was cemented into the remaining $2 \mathrm{ft}$ of annulus and the finish hand-troweled so that surface water drains away.

In addition to the seven wells constructed in 2005, 2NDNATURE had contracted construction of four observation wells in August 2003 for an earlier project. These wells were used to monitor water levels and ground-water quality for this investigation. Domestic wells and wells not included in the real-time-kinematic survey were located with a hand-held Global Positioning System and altitudes were determined with a laser level (table 1).

\section{Aquifer Characteristics}

Hydraulic conductivity near the Park Avenue detention basins ranged from 0.3 to $20 \mathrm{ft} / \mathrm{d}$ for sandy clay and medium sand (table 2). Hydraulic conductivity was estimated from the results of slug tests in eight wells that were analyzed with the method described by Bouwer and Rice (1976). Results from these slug tests constrained ground-water velocity estimates utilized in the ground-water flow model, which control transport and travel times of nutrients.

\section{Sub-Littoral Ground-Water Discharge to Lake Tahoe}

Water exchange between Lake Tahoe and the adjacent aquifer system is controlled by the hydraulic gradient and permeability of the lakebed and aquifer material. Lakebed permeability is variable due to fluvial processing of deltaic sediments and texture of basin-fill deposits, wave sorting of beach deposits, and the mineralogy of parent rock (which controls the size and uniformity of sediment grains resulting from weathering). The hydraulic gradient controls the direction of ground-water exchange between lake and aquifer, and the energy available to move water through variably permeable deposits. Lake Tahoe receives most of its inflow as snowmelt runoff and is managed as a storage reservoir, such that the hydraulic gradient may be subject to artificial variability and possible gradient reversals (Winter and others, 1998, p. 18). 
Table 1. Information regarding data-collection sites used to investigate responses of shallow ground water receiving stormwater runoff from Park Avenue stormwater control system, South Lake Tahoe, California, 2005-07.

[Site locations are shown in figure 3 and $\underline{4}$. Site designations: The local identification is based on the rectangular subdivision of the public lands referenced to the Mount Diablo base line and meridian. Each number consists of three units. The first is the township, preceded by $\mathrm{N}$ to indicate location north of the base line. The second unit is the range, preceded by $\mathrm{E}$ to indicated location east of the meridian. The third unit consists of the section number and letter designating which is a unique number based on grid system of latitude and longitude of the site. For wells MW194-MW202, which are located in California, wells are numbered according to their location in the rectangular system for subdivision of public lands. Identification consists of the township number, north or south (N or S); the range number, east or west (E or W); and the section number. Each section is divided into sixteen 40 -acre tracts lettered consecutively (except I and O) beginning with "A" in the northeast corner of the section and progressing in a sinusoidal manner to " $\mathrm{R}$ " in the southeast corner. Within the 40-acre tract, wells are sequentially numbered in the order they are inventoried. The standard identification consists of 15 digits: First six denote degrees, minutes, and seconds of latitude; next seven denote degrees, minutes, and seconds of longitude; and last two digits (assigned sequentially) identify sites within 1-second grid. If more precise latitude and longitude subsequently are determined, initial site-identification number is retained. The eight-digit numbers are station numbers that follow the "downstream-order system": The first two digits, or part number, refer to the regional drainage basin (Part 10 is Great Basin). The following six digits are the downstream-order number, which is assigned according to the geographic location of the site in the drainage basin; larger numbers stations are downstream from the smaller number stations. Land-surface altitude: Vertical accuracy \pm 1.97 inches. Site type: SWI, stormwater inflow; DBG, detention basin gage; SWO, stormwater outflow; OBS, observation well; DOM, domestic well; LAKE, Lake Tahoe sample site. Abbreviation: NA, not applicable or not available]

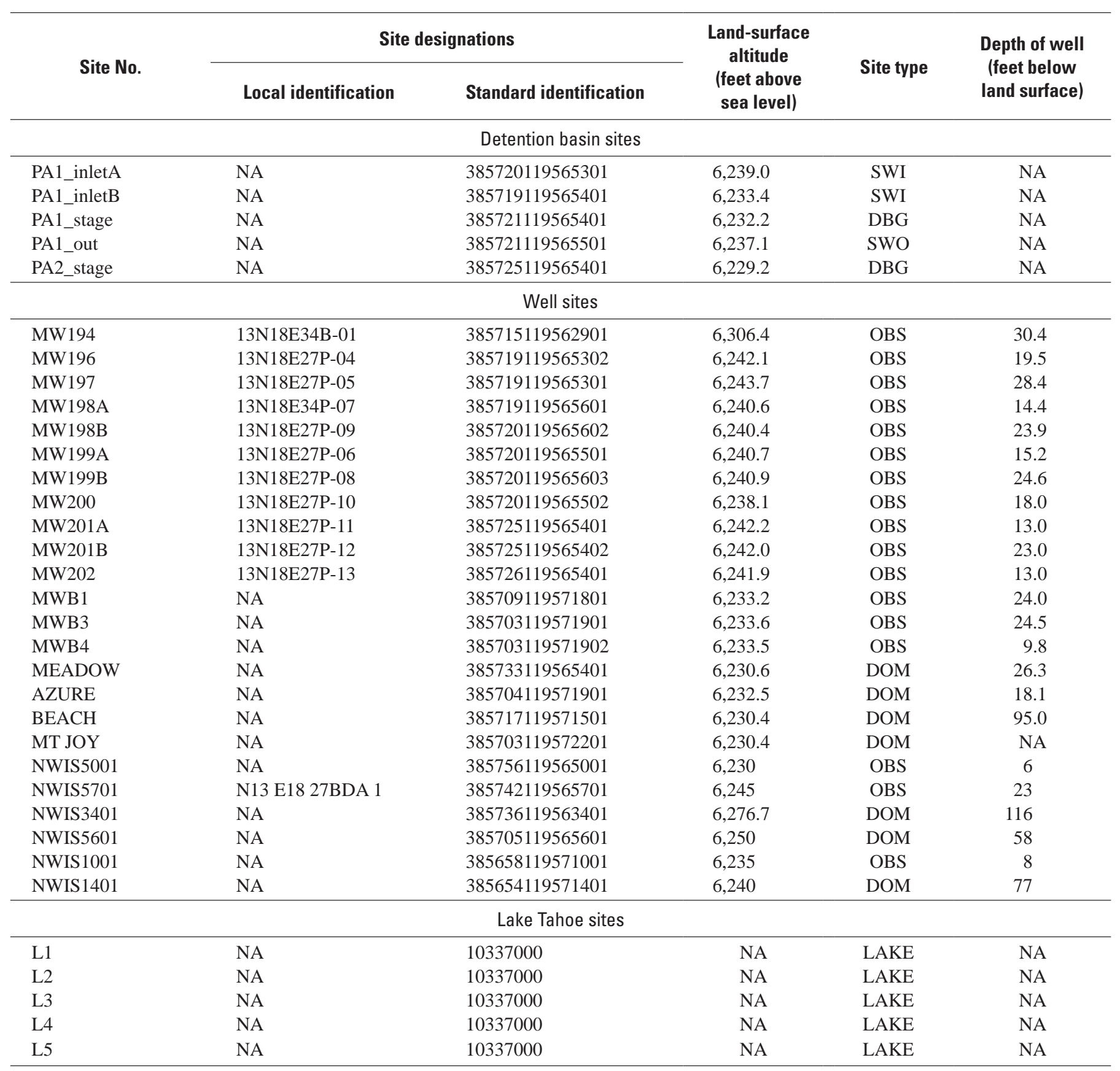


Table 2. Estimated results of monitoring well slug tests near Park Avenue stormwater control system, South Lake Tahoe, California.

[Sites are shown in figure 3. Abbreviations: $\mathrm{ft}$, foot; ft/d, foot per day]

\begin{tabular}{|c|c|c|c|c|c|c|c|}
\hline \multirow[t]{2}{*}{ Site No. } & \multirow{2}{*}{ Date of test } & \multirow{2}{*}{$\begin{array}{c}\text { Initial } \\
\text { water-level } \\
\text { altitude } \\
\text { (ft) }\end{array}$} & \multirow{2}{*}{$\begin{array}{l}\text { Aquifer material at } \\
\text { screened interval }\end{array}$} & \multirow{2}{*}{$\begin{array}{c}\text { Mean } \\
\text { displacement } \\
\text { (ft) }\end{array}$} & \multirow{2}{*}{$\begin{array}{c}\text { Number of } \\
\text { tests }\end{array}$} & \multicolumn{2}{|c|}{$\begin{array}{l}\text { Hydraulic conductivity } \\
\text { (ft/d) }\end{array}$} \\
\hline & & & & & & Mean & Range \\
\hline MW-194 & 06-07-06 & $6,292.2$ & Sandy clay & 1.82 & 2 & 0.9 & $0.9-0.9$ \\
\hline MW-196 & 06-06-06 & $6,231.7$ & Medium sand & 1.67 & 2 & 0.3 & $0.3-0.4$ \\
\hline MW-197 & 06-06-06 & $6,239.0$ & Medium sand & 1.74 & 3 & 4 & $2-5$ \\
\hline MW-198A & 06-07-06 & $6,231.1$ & Medium sand & 1.80 & 2 & 0.8 & $0.6-1$ \\
\hline MW-198B & 06-07-06 & $6,230.9$ & Medium sand & 1.55 & 2 & 7 & $2-20$ \\
\hline MW-199A & 06-07-06 & $6,230.9$ & Medium sand & 0.90 & 3 & 20 & 20 \\
\hline MW-199B & 06-07-06 & $6,230.9$ & Medium sand & 1.99 & 2 & 3 & $2-3$ \\
\hline MW-201B & 06-06-06 & $6,230.2$ & Medium sand & 1.05 & 4 & 8 & $6-10$ \\
\hline
\end{tabular}

Estimates of ground-water discharge to Lake Tahoe have been made using regionalized values of onshore aquifer hydraulic properties. The mass of nutrients transported to the lake with ground water was estimated by coupling groundwater volume with averaged nutrient concentrations (U.S. Army Corps of Engineers, 2003; Thodal, 1997). Growing acceptance that ground water is a significant variable to consider in water and nutrient budgets of surface water (Winter and others, 1998; Brock and others, 1982) has led to the development of a variety of novel hydrological tools used to quantify and corroborate the connection between lakes and ground-water systems (Schuster and others, 2003).

\section{Water-Quality Sampling Procedures and Analytical Methods}

A total of 95 ground-water and 37 stormwater samples were collected following procedures described in USGS National Field Manual for the Collection of Water-Quality Data (variously dated). The collection of samples were made prior to and during snowmelt runoff (November 2005-May 2006 and December 2006-April 2007) and sent to High Sierra Water Laboratory in Truckee, California, for determination of nutrients (Kjeldahl nitrogen; ammonium; nitrate plus nitrite, phosphorus and soluble reactive phosphate; American Public Health Association, 1998; Solorzano, 1969; Liddicoat and others, 1975; Woodworth and Conner, 2003). Ground-water samples were collected after well purging by using a bailer dedicated to each observation well or a portable submersible pump. Subsamples were filtered through a $0.45-\mu \mathrm{m}$ mixed cellulose ester membrane for laboratory analyses. Unfiltered stormwater samples were collected by the open-mouth bottle method with subsamples filtered through a $0.45-\mu \mathrm{m}$ mixed cellulose ester membrane for determination of ammonium, nitrate plus nitrite, and orthophosphate-phosphorus. Concentrations of organic nitrogen and hydrolysable phosphorus were estimated by subtracting laboratory values of ammonium-nitrogen from Kjeldahl-nitrogen, and orthophosphate-phosphorus from phosphorus, respectively. In addition, ground-water samples were collected in February 2006 for field determination of filtered concentrations of bicarbonate and alkalinity (Rounds, 2006) and laboratory determination of stable isotope ratios of oxygen and hydrogen (Epstein and Mayeda, 1953; Coplen and others, 1991; Coplen, 1994) and filtered concentrations of organic carbon (Brenton and Arnett, 1993), major ions, silica, chromium, copper, iron, lead, nickel, and zinc (Fishman and Friedman, 1989; Fishman, 1993). Isotope samples were shipped to the USGS Reston Stable Isotope Laboratory in Reston, Virginia and other samples were shipped to the USGS National Water Quality Laboratory in Lakewood, Colorado.

Ten samples of lake and interstitial water also were collected from five locations along the shoreline of Lake Tahoe (fig. 3). A multiparameter meter was used to measure temperature, $\mathrm{pH}$, specific conductance, and dissolved oxygen of the lakewater prior to sample collection. Lakewater samples were collected from $1 \mathrm{ft}$ beneath the water surface and from the water-lakebed interface using 0.25-in. diameter polyethylene tubing and a $60 \mathrm{~mL}$ syringe at a rate of $30 \mathrm{~mL} /$ min. Interstitial water was collected by pushing a 0.5 -in. diameter minipeizometer $0.8 \mathrm{ft}$ beneath the lakebed and withdrawing water through 0.25 -in. diameter tubing and a $60 \mathrm{~mL}$ syringe at $30 \mathrm{~mL} / \mathrm{min}$. Unfiltered water was collected for stable isotope analysis (Epstein and Mayeda, 1953; Coplen and others, 1991; Coplen, 1994). Subsamples were passed through $0.45-\mu \mathrm{m}$ Supor ${ }^{\circledR}$ syringe filters into $125-\mathrm{mL}$ opaque polyethylene bottles and chilled on ice for overnight shipment for nutrient analyses by the USGS National Water Quality Laboratory (Fishman, 1993; Patton and Kryskalla, 2003). Laboratory reporting levels of each analyte are listed in table 3. All water-quality data are listed in appendix A (at back of report). 
Table 3. Constituents determined in water and sediment samples and laboratory reporting levels.

[Values are ratios mathematically related to comparable ratios for an international standard. Abbreviations: $\delta$, delta; NA, not applicable]

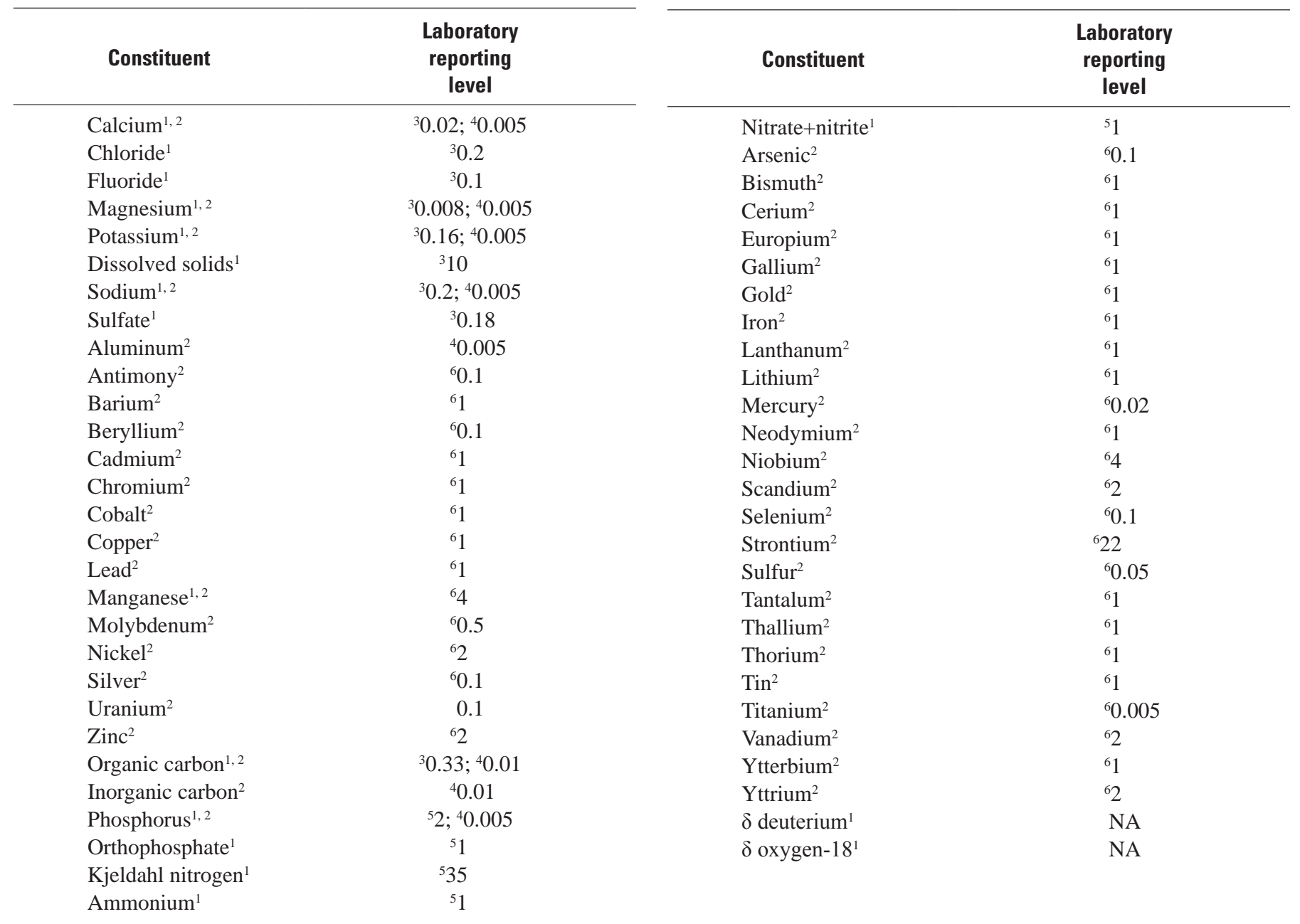

${ }^{1}$ Constituent determined in water samples.

${ }^{2}$ Determined in sediment samples.

${ }^{3}$ Reporting level in milligrams per liter.

${ }^{4}$ Reporting level in percent.

${ }^{5}$ Reporting level in micrograms per liter.

${ }^{6}$ Reporting level in micrograms per gram.

\section{Collection of Bottom-Sediment Samples}

Two bottom-sediment samples were collected from site PA1 (fig. 4A) on August 31, 2005, using a 2-ft split-spoon sampler with polyethylene core liner and soft-fingered core catcher. The sampler was driven $2 \mathrm{ft}$ into the sediment about $20 \mathrm{ft}$ from the PA1_inletA. The resulting core was extruded into two glass bowls for processing. One bowl included the uppermost $0.2 \mathrm{ft}(0-0.2 \mathrm{ft})$ of dark grey sediment and the other bowl contained $0.2 \mathrm{ft}$ of brown-orange sediment from
1.5-1.7 ft beneath the sediment surface. Each sample was homogenized thoroughly with a Teflon policeman and about $100 \mathrm{~g}$ was transferred into 1-L widemouth glass jars that had been baked to $450^{\circ} \mathrm{C}$. These samples were placed in an ice chest and shipped overnight to the USGS National Water Quality Laboratory for determination of selected polycyclic aromatic hydrocarbon compounds (table 4) following analytical procedures described by Arbogast (1996), Hageman (2007), Taggart (2002), and Briggs and Meier (1999). 
Table 4. Polycyclic aromatic hydrocarbon compounds determined in bottom-sediment samples collected from stormwater control basin, site PA1, South Lake Tahoe, California, and laboratory reporting levels.

[Laboratory reporting level in micrograms per kilogram]

\begin{tabular}{lc}
\hline \multicolumn{1}{c}{ Compound } & $\begin{array}{c}\text { Laboratory } \\
\text { reporting level }\end{array}$ \\
\hline Acenaphthene & 10 \\
Acenaphthylene & 10 \\
Anthracene & 10 \\
Benz[a]anthracene & 10 \\
Benz[a]pyrene & 10 \\
Benzo[b]fluoranthene & 10 \\
Benzo[e]pyrene & 10 \\
Benzo[g,h,i]perylene & 10 \\
Benzo[k]fluoranthene & 10 \\
Chrysene & 10 \\
Dibenz[a,h]anthracene & 10 \\
1,2-Dimethylnaphthalene & 10 \\
1,6-Dimethylnaphthalene & 10 \\
2,6-Dimethylnaphthalene & 10 \\
2-Ethylnaphthalene & 10 \\
Fluoranthene & 10 \\
Fluorene & 10 \\
Indeno[1,2,3-cd]pyrene & 10 \\
2-Methylanthracene & 10 \\
1-Methyl-9H-fluorene & 10 \\
1-Methylphenanthrene & 10 \\
1-Methylpyrene & 10 \\
Naphthalene & 10 \\
Perylene & 10 \\
Phenanthrene & 10 \\
Pyrene & \\
2,3,6-Trimethylnaphthalene & 10 \\
\hline
\end{tabular}

The sediment remaining in each bowl was sieved through precleaned 62.5- $\mu \mathrm{m}$ nylon mesh using a Teflon policeman and native water. About $10 \mathrm{~g}$ of the resulting fine-grained fraction was placed in 500-mL polypropylene widemouth jars and shipped to the USGS Branch of Geochemistry Laboratory in Lakewood, Colorado, for determination of selected metals, and inorganic and organic carbon (table 4), following analytical methods describe by Olson and others (2004). Laboratory reporting levels of each analyte are listed in tables 3 and 4 . All bottom-sediment quality data are listed in appendix B (at back of report).

\section{Simulation of Ground-Water Flow}

The effects of an engineered stormwater-control system on shallow ground-water flow adjacent to Lake Tahoe were simulated using a three-dimensional, finite-difference, ground-water flow model (hereafter referred to as the model). Included are descriptions of the basin-fill aquifer and quantification of components of the ground-water budget. Model results are presented as a tool to evaluate responses of ground-water flow to stormwater-runoff accumulation in the stormwater-control system. The model simulated groundwater flow and seepage across the lake interface.

\section{Flow Model Description}

Ground-water flow through the basin-fill aquifer beneath the study area was simulated using MODFLOW, a threedimensional, numerical (finite-difference) ground-water flow model (McDonald and Harbaugh, 1988; Harbaugh and McDonald, 1996). The model area was discretized into a grid of 23,925 rectangular model cells in 165 rows and 145 columns areally and 6 layers vertically. Each model cell was about $66 \mathrm{ft}$ wide in the row and column dimensions and had variable thickness. The model grid was rotated 25 degrees clockwise about row 83 and column 73 (UTM NAD 1983, zone $10 \mathrm{~N} 763,855.52,4,316,204.58$ meters) so that the major axes were parallel to the general direction of ground-water flow, which generally is toward the lake in the model domain. Rotation of the grid caused 43 percent of the cells to fall outside the area of interest; therefore these cells were inactive. The top of layer 1 represented land surface and covered about $2.1 \mathrm{mi}^{2}$. The southeast boundary extended upgradient to where bedrock is quite shallow, generally along the 6,350-ft topographic line. A sharp dropoff of the lake bottom served as the submerged northwest boundary (ig. 5).

Aquifer thickness generally is very thin near the upgradient southeast boundary and thickens toward and under the lake (fig. 6). Total aquifer thickness along the upgradient boundary mostly is less than $50 \mathrm{ft}$, while along the northwest boundary beneath Lake Tahoe, it is nearly 1,500 ft thick (Eric LaBolle, University of California, Davis, written commun., 2006). 


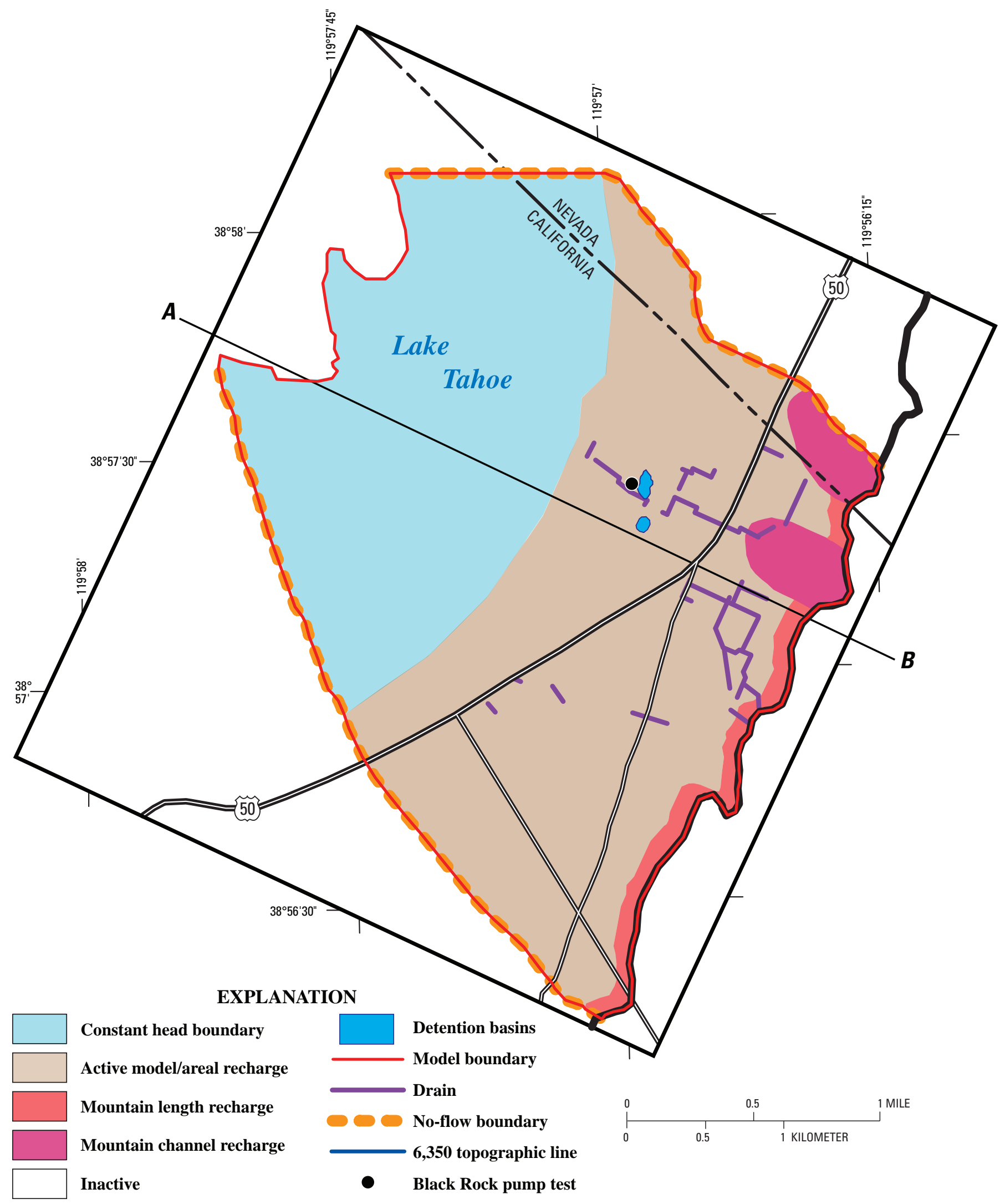

Figure 5. Layer 1 boundary conditions in steady-state ground-water flow model, South Lake Tahoe, California and Nevada. 


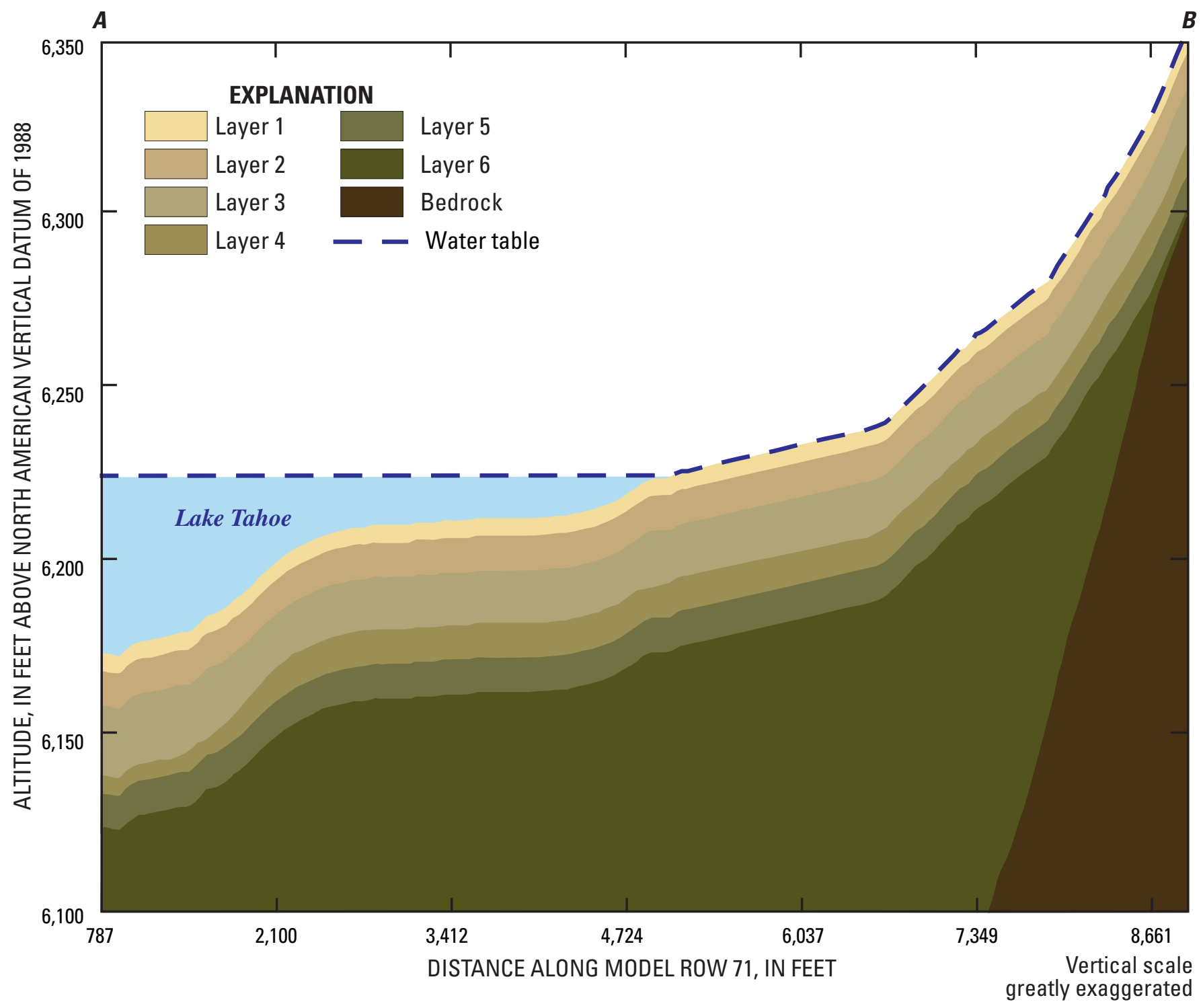

Figure 6. Cross section of the modeled area along row 71, South Lake Tahoe, California and Nevada. Location of cross section is shown in figure 5 .

The model objective was to understand movement of shallow ground water; therefore a finer discretization was used in the upper $50 \mathrm{ft}$ of the model domain (ig. 6). Model layer thicknesses in layers $1-5$ were designed to keep uniform thickness throughout each individual layer. Layer 1 was a constant $5 \mathrm{ft}$ thick, while layer 2 was a constant $10 \mathrm{ft}$ thick. Layers 3-5 were each a constant 15,10 , and $10 \mathrm{ft}$ thick, respectively. Layer 6 varies in thickness from the bottom of layer 5 to bedrock. The large and varying thickness of layer 6 is assumed to have no effect on the simulation of shallow ground-water movement, although it likely stores a large quantity of ground water. Discontinuous lacustrine units typically are less than $20 \mathrm{ft}$ in thickness and likely are reworked by meandering streams; therefore a continuous confining unit was not simulated in this model.

\section{Boundary Conditions}

Shallow ground-water flow was simulated as a steadystate flow system. Annual Lake Tahoe stage fluctuations will have a time-varying effect on nutrient loads discharged by ground water, although in evaluating the suitability of a detention basin as a BMP, long term loading is more of a concern. Therefore, modeling the transient ground-water system as a steady-state flow system is considered sufficient for the model objectives.

Various boundary conditions were used across the model (fig. 5). All interior model cells exposed to Lake Tahoe in the northwest were simulated using a constant-head boundary of 6,225 ft, which is the average stage of Lake Tahoe over the study period. The southern Park Avenue detention basin (PA1), 
which contained standing water throughout the study, also was simulated using a constant-head boundary in six contiguous cells. A network of stormwater drainage ditches and sewers scattered across South Lake Tahoe were simulated using drains (Jim Marino, city of South Lake Tahoe, written commun., 2006). These drains were placed $5 \mathrm{ft}$ below land surface. In this way, if the simulated ground-water surface came within $5 \mathrm{ft}$ of land surface, ground water would discharge to the stormwater ditches and flow directly to Lake Tahoe.

Recharge was applied to the onshore modeled area by areal recharge and mountain-front recharge from watersheds upgradient of the study area. Areal recharge, for the purposes of this model, was defined as precipitation that passes beneath the root zone and crosses the water table. All layer 1 onshore pervious model cells or those cells simulated as not being impervious due to urbanization (about 62 percent of all active layer 1 cells; Raumann, 2007) received areal recharge. The volume of areal recharge was estimated during model calibration and constrained by local precipitation and evapotranspiration estimates.

Mountain-front recharge was defined as surface runoff from contributing watersheds that flows over bedrock and infiltrates at the bedrock-alluvium contact. Mountain-front recharge was applied to all cells along the southeast domain boundary, as well as to two adjacent zones that extend northwest from the mountain front (fig. 5). The two larger zones represent small drainages where coarser grained material is present (Rogers, 1974); therefore, mountain-front recharge naturally is greater in these locations (fig. 7). The volume of annual precipitation averaged 4,400 acre-ft in the watersheds upgradient of the model area between 1971 and 2000 (Flint and Flint, 2007). Results from Flint and Flint indicated that of the total precipitation about 2 percent becomes in-place recharge, 54 percent is consumed by evapotranspiration, and the remaining 44 percent is attributed to potential runoff. The percentage of the potential runoff that actually becomes mountain-front recharge was estimated during model calibration.

No-flow boundary conditions were used in several locations in the model (fig. 5). Bedrock underlies all of layer 6 and represents a no-flow boundary. Model boundaries to the northeast and southwest were aligned along hydrologic basin boundaries (Cartier and others, 1995) and therefore were represented as no-flow boundaries.

\section{Model Calibration}

Calibration is the attempt to reduce the difference between model results and measured data by adjusting model parameters. The improvement of the calibration is based on minimizing the differences between simulated and measured ground-water levels. The discrepancy between model results and measurements (known as the residual) commonly is, in part, the cumulative result of simplification of the natural system by the conceptual model, the model grid, and the scarcity of sufficient data to account for the spatial variation in hydraulic properties and recharge throughout the study area.

Uniform hydraulic conductivity distributions were assigned throughout all model layers because of limited hydraulic information. Calibration was constrained by assuming the transmissivity of the alluvial aquifer was known from a pump test completed in wells near the Park Avenue detention basins. Transmissivity is equal to the hydraulic conductivity of aquifer materials, multiplied by the aquifer thickness. The pump test completed by the South Tahoe Public Utility District yielded transmissivity estimates of $1,800 \mathrm{ft}^{2} / \mathrm{d}$ (fig. 5; Bergsohn, 2000). Horizontal hydraulic conductivity was $2 \mathrm{ft} / \mathrm{d}$ and was not estimated during model calibration. This resulted in a transmissivity estimate of $2,000 \mathrm{ft}^{2} / \mathrm{d}$ near the Lake Tahoe shoreline, where the aquifer has a thickness of about 1,000 ft (fig. 6). This is reasonable as it falls into the $0.3-20 \mathrm{ft} / \mathrm{d}$ range of values (median value of $3 \mathrm{ft} / \mathrm{d}$ ) estimated from slug tests (table 2). Discontinuous lacustrine units were assumed to be distributed uniformly throughout the aquifer and were simulated in the average vertical hydraulic conductivity. Vertical hydraulic conductivity was assumed to be lower in the six cells between layers 1 and 2 beneath PA1 because of sediment compaction during basin construction. Vertical hydraulic conductivities were estimated during model calibration.

The ground-water flow model was calibrated to average water-level measurements in 18 wells. The following weighted (w)i, sum-of-squares (SS) objective function was minimized during calibration,

$$
S S=\sum_{i=1}^{n w l}\left(\hat{h}_{i}-h_{i}\right)^{2} w_{i}
$$

where

$\hat{h}$ is simulated water levels, in feet;

$h_{i}$ is measured water levels, in feet; and

$n w l$ is the number of water level measurement:

Note: The root-mean-square (RMS) error is reported instead because RMS error is more directly comparable to actual values and serves as a composite of the average and the standard deviation of a set. RMS error is related to SS error by

$$
R M S=\sqrt{\frac{S S}{\sum_{i=1}^{n w l} w_{i}}} .
$$




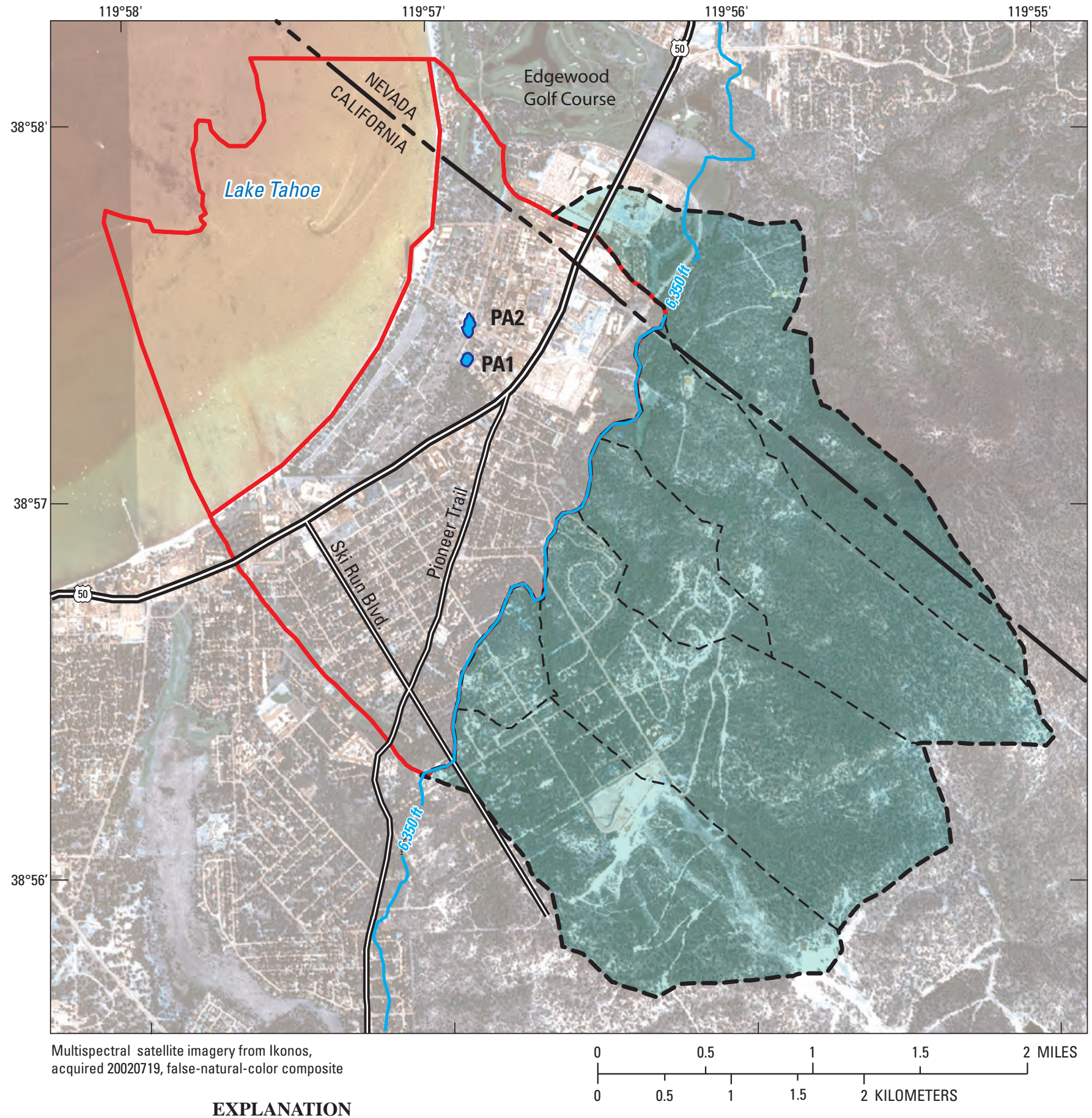

[_- Upland watersheds contributing

mountain front recharge to

modeling domain watersheds

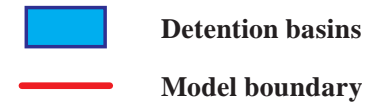

$-6,350$ - Topographic line

Figure 7. Upgradient watersheds used to calculate mountain-front recharge, South Lake Tahoe, California and Nevada. 
Model calibration was further facilitated by parameter estimation. Estimated parameters included (1) the volume of potential runoff generated in the watersheds adjacent to the modeled area that becomes mountain-front recharge along the southeast boundary, (2) the volume of areal recharge distributed homogeneously to pervious model cells, (3) the vertical hydraulic conductivity in the area surrounding the Park Avenue detention basins, (4) the vertical hydraulic conductivity of the remaining aquifer, and (5) stormdrain conductance.

Each parameter was changed a small amount and MODFLOW was used to compute new water levels for each perturbed parameter. As a secondary calibration procedure, recharge rates were bracketed within 200 and 450 acre-ft/yr (Flint and Flint, 2007). Vertical hydraulic conductivity near Park Avenue detention basins, also was given an upper limit lower than that of estimates at Cattlemans detention basin of $0.027 \mathrm{ft} / \mathrm{d}$ because PA1 remains wet year round, whereas Cattlemans is dry for many months per year (Green, 2006). An iterative process was followed by estimating parameters, running revised models using the estimated parameters, and calculating new water levels until the objective function change was minimize and could not be improved.

\section{Model Results}

The final calibrated model was the best fit possible of the observed water levels given the parameter constraints described above. Simulated water levels representative of conditions from 2005 to 2007 approximated the 18 measured water levels in the modeled area (fig. 8). Fourteen shallow wells were screened within layers 1 and 2 (within $15 \mathrm{ft}$ below the water table) and 4 deep wells were screened within layer 3 (between 15 and $30 \mathrm{ft}$ below the water table). However, simulated water levels did not exactly reproduce all measured water levels in all wells. Figure 9 shows the simulated waterlevel contours and monitoring well residuals. Measured water levels in a cluster of wells within about $300 \mathrm{ft}$ of each other in the south-central part of the model (wells B-3, B-4, Beach, and Azure) ranged about $1.5 \mathrm{ft}$. The flow model assumes homogeneous aquifer properties and therefore was not able to simulate such a span of water levels in close proximity to each other. Simulated water levels near model boundaries may be less reliable than simulated water levels that are distant from boundaries. Boundary effects are most notable when there are nearby stresses. For instance, detention basin PA1 was simulated with a constant-head boundary of 6,234 ft.

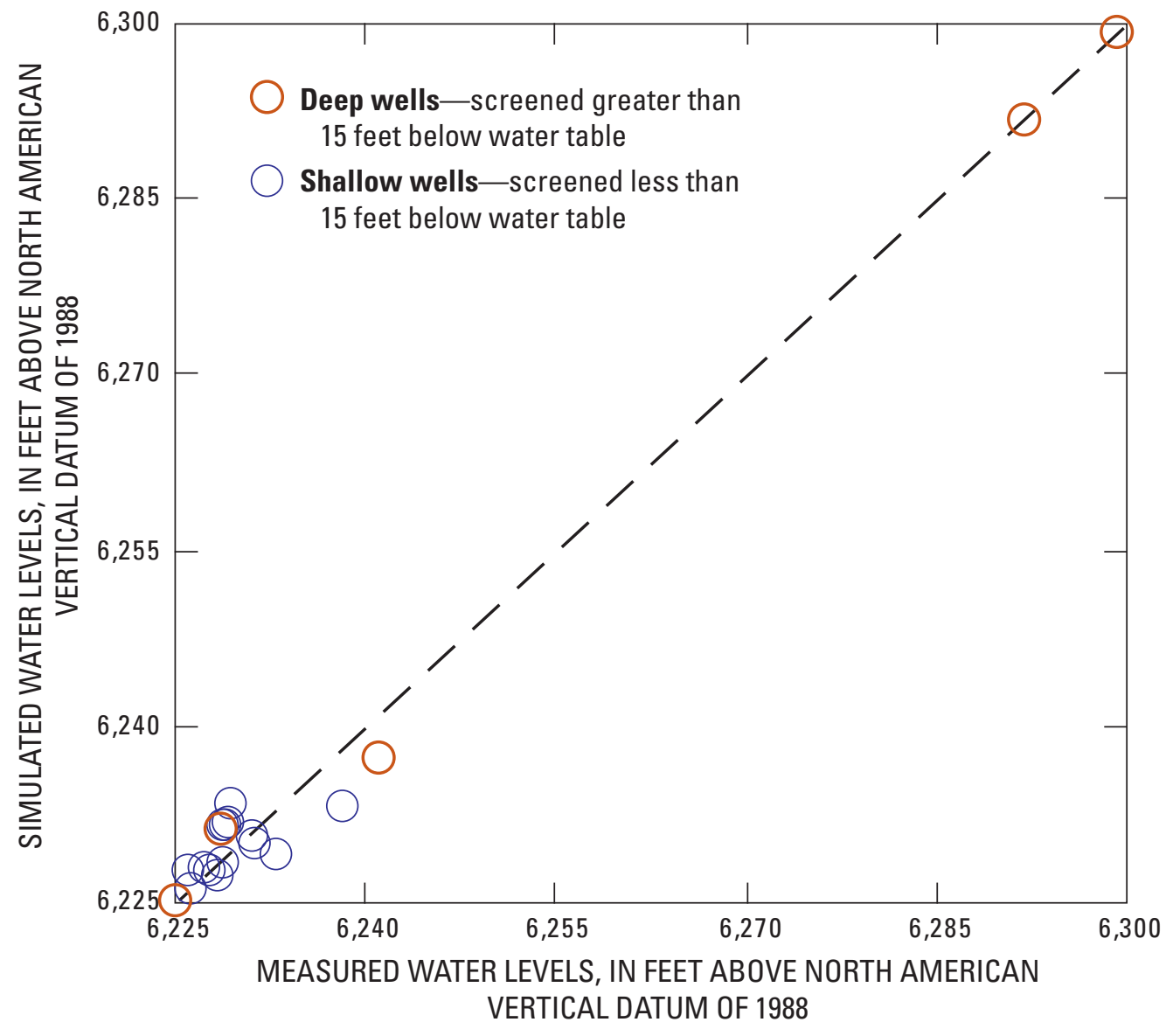

Figure 8. Measured water levels compared with model-simulated water levels, South Lake Tahoe, California and Nevada. 


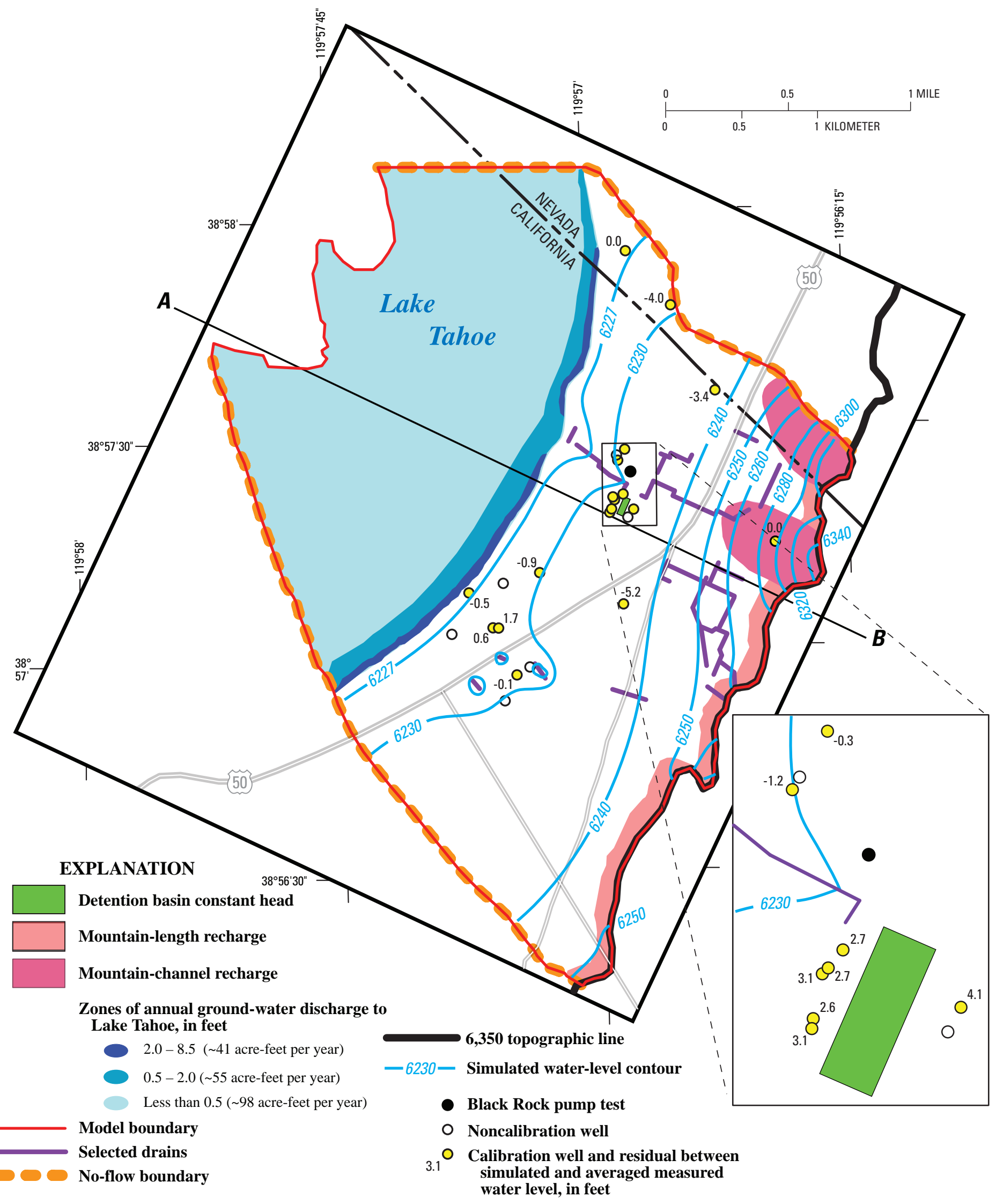

Figure 9. Calibrated model simulated water-level contours, monitoring well residuals (simulated-average observed values), and simulated annual ground-water discharge to South Lake Tahoe, California and Nevada. 
Observed water levels in wells upgradient and downgradient of PA1, however, were 4-5 ft lower than this level. Therefore, the model was not able to simulate accurately such a localized field condition. During the construction of PA1, sediment possibly was compacted in the basin, resulting in stormwater inflow being semiperched above the regional water table. Small drains discharging water in the south-central part of the model near wells B-1 and NWIS5601 also affected the accurate calibration of water-level contours. Average measured water levels in these wells differed by $10.5 \mathrm{ft}$, and therefore had rather large simulated residuals. The final calibrated model produced a RMS error of $2.55 \mathrm{ft}$.

The final calibrated values for model parameters are listed in table 5, and components of the water budget are shown in figure 10. Total mountain-front recharge was estimated as 306 acre- $\mathrm{ft} / \mathrm{yr}$. This value is comprised of 2 percent of precipitation as in-place recharge as computed by the Basin Characterization Model of Flint and Flint (2007) and a calibrated value of 16 percent of runoff becoming recharge. These values are within the bounds present by Flint and Flint (2007). Areal recharge was estimated quite low at about 5 acre-ft/yr and recharge from detention basin PA1 was about 1 acre-ft/yr. Drains used to simulate storm ditches were estimated to discharge about 56 acre-ft/yr, allowing ground water to exit the subsurface and discharge to the lake. Direct ground water discharge from the study area to Lake Tahoe was 256 acre-ft/yr. About 75 percent of ground-water discharge to Lake Tahoe occurs from layer 1 . The distribution is shown in figure 10.

\section{Model Sensitivity}

To determine how model parameters affected simulation results, all estimated parameters were varied independently from 0.2 to 5 times their calibrated value. This range was greater than the uncertainties associated with the parameters, but provided a more complete perspective on model sensitivity. Model sensitivity was described in terms of the RMS error. The sensitivity of model results to changing one parameter while all others are held at their calibrated values is shown in figure 11. Residuals were determined to be more sensitive to changes in mountain-front recharge, especially through the course-grained channel to the northeast than to any other model parameters. Model results were rather insensitive to storm-drain conductance and vertical hydraulic conductivity of the detention basin and the rest of the model.

Model sensitivity to specified boundary conditions and hydraulic properties was further investigated with four alternative models. Alternative models included increasing the stage of Lake Tahoe within the constant-head boundary to $6,229 \mathrm{ft}$ (historical high watermark), lowering it to $6,223 \mathrm{ft}$ (altitude of lake outlet at Tahoe City Dam), incorporating a clay layer into the hydrogeology, and increasing the model horizontal hydraulic conductivity from 2 to $4 \mathrm{ft} / \mathrm{d}$. The continuous clay layer was simulated in the model by reducing the horizontal hydraulic conductivity of only layer 3 to $0.001 \mathrm{ft} / \mathrm{d}$. Each alternative model was calibrated after changing the selected boundary conditions and hydraulic properties. Results of these alternative models are listed in table 5.

Table 5. Model parameters and their calibrated values, in order of sensitivity for original model, South Lake Tahoe, California and Nevada.

[Abbreviations: acre-ft/yr, acre-foot per year; ft/d, foot per day; ft, foot]

\begin{tabular}{|c|c|c|c|c|c|}
\hline \multirow[b]{2}{*}{ Parameter name } & \multicolumn{5}{|c|}{ Model run parameter estimates } \\
\hline & Original & Lower stage & Raised stage & $\begin{array}{c}\text { Clay layer } \\
\text { present }\end{array}$ & $\begin{array}{c}\text { Horizontal } \\
\text { hydraulic } \\
\text { conductivity } \\
(4 \mathrm{ft} / \mathrm{d})\end{array}$ \\
\hline Mountain-front recharge (acre-ft/yr) & 306 & 322 & 205 & 278 & 495 \\
\hline Channel recharge (acre-ft/yr) & 160 & 163 & 177 & 137 & 338 \\
\hline Mountain-length recharge (acre-ft/yr) & 146 & 159 & 28 & 141 & 157 \\
\hline Basin vertical hydraulic conductivity (ft/d) & 0.0024 & 0.0024 & 0.0024 & 0.0024 & 0.0024 \\
\hline Areal recharge (acre-ft/yr) & 5 & 5 & 5 & 5 & 5 \\
\hline Aquifer vertical hydraulic conductivity (ft/d) & 0.33 & 0.32 & 0.98 & 0.33 & 0.36 \\
\hline Storm-drain discharge (acre-ft/yr) & 56 & 39 & 94 & 48 & 80 \\
\hline Discharge to Lake Tahoe (acre-ft/yr) & 256 & 289 & 116 & 236 & 421 \\
\hline Model root mean square error (RMS) (ft) & 2.55 & 2.67 & 1.31 & 2.64 & 2.54 \\
\hline
\end{tabular}



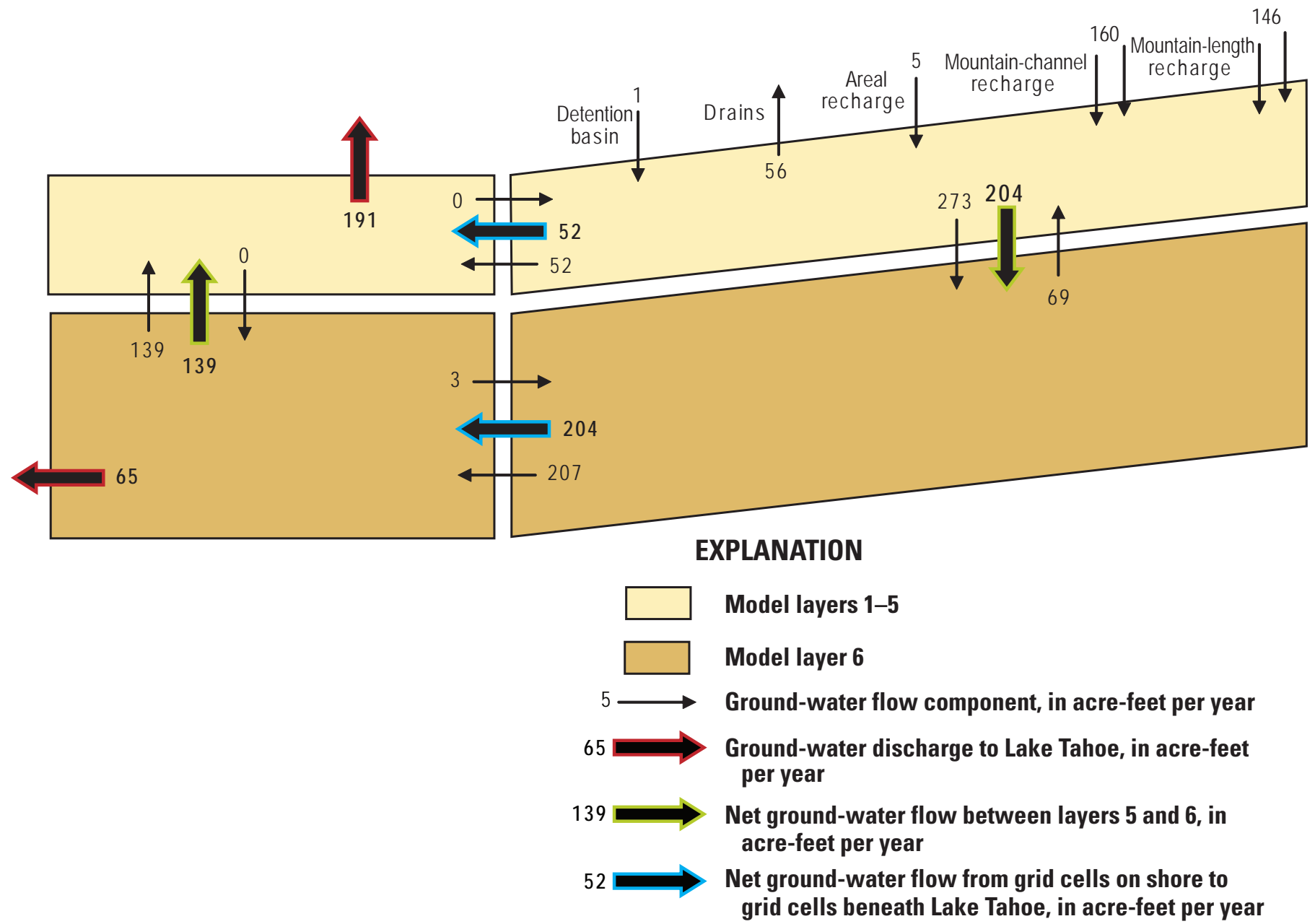

Figure 10. Estimated ground-water budget for model area, South Lake Tahoe, California and Nevada.

Computed RMS error of the four alternative models varied by about $1.4 \mathrm{ft}$. Raising the stage of Lake Tahoe had the greatest effect on the model error by reducing it by about $1.2 \mathrm{ft}$. As expected, discharge to Lake Tahoe was reduced when the stage of Lake Tahoe was increased because it has a direct effect on the hydraulic gradient within the model. In response to a shallower gradient, the mountain-front recharge was decreased within the calibration process to allow ground-water levels in the aquifer to approach their observed elevations. Model error was insensitive to simulations of (1) lowering the stage of Lake Tahoe, (2) layer 3 representing a continuous clay layer, and (3) increasing the horizontal hydraulic conductivity to $4 \mathrm{ft} / \mathrm{d}$.

\section{Model and Data Limitations}

The flow model reasonably describes local ground-water flow near the Park Avenue detention basins, but it cannot mimic exactly the true ground-water flow system. Simulated values often are similar to, but do not match precisely with the measured values. The ground-water flow model is a numerical approximation of the flow system, and is limited by simplifications in the conceptual model, discretization effects, and the scarcity of measurements to account for the spatial variation in hydraulic properties throughout the study area.

Inherent in the conceptual model is the assumption that all sources of flow and stresses on the natural system are represented in the numerical model. Because measurements of water levels used to constrain the model calibration were made over a short time period, it is not known how completely or how accurately the numerical model simulates the natural system, especially under steady-state conditions.

Areal discretization of the study area into a rectangular grid of cells and vertical discretization into layers required averaging of hydraulic properties. Each model cell represents an averaged block of the aquifer system. Due to this averaging, the model cannot simulate the local effects on flow caused by aquifer heterogeneity. Further simplification of the heterogeneous aquifer system occurred in the methods used to describe the distribution of the hydraulic conductivity. The lack of sufficient measurements to account for the spatial variations in hydraulic properties necessitated the uniform 


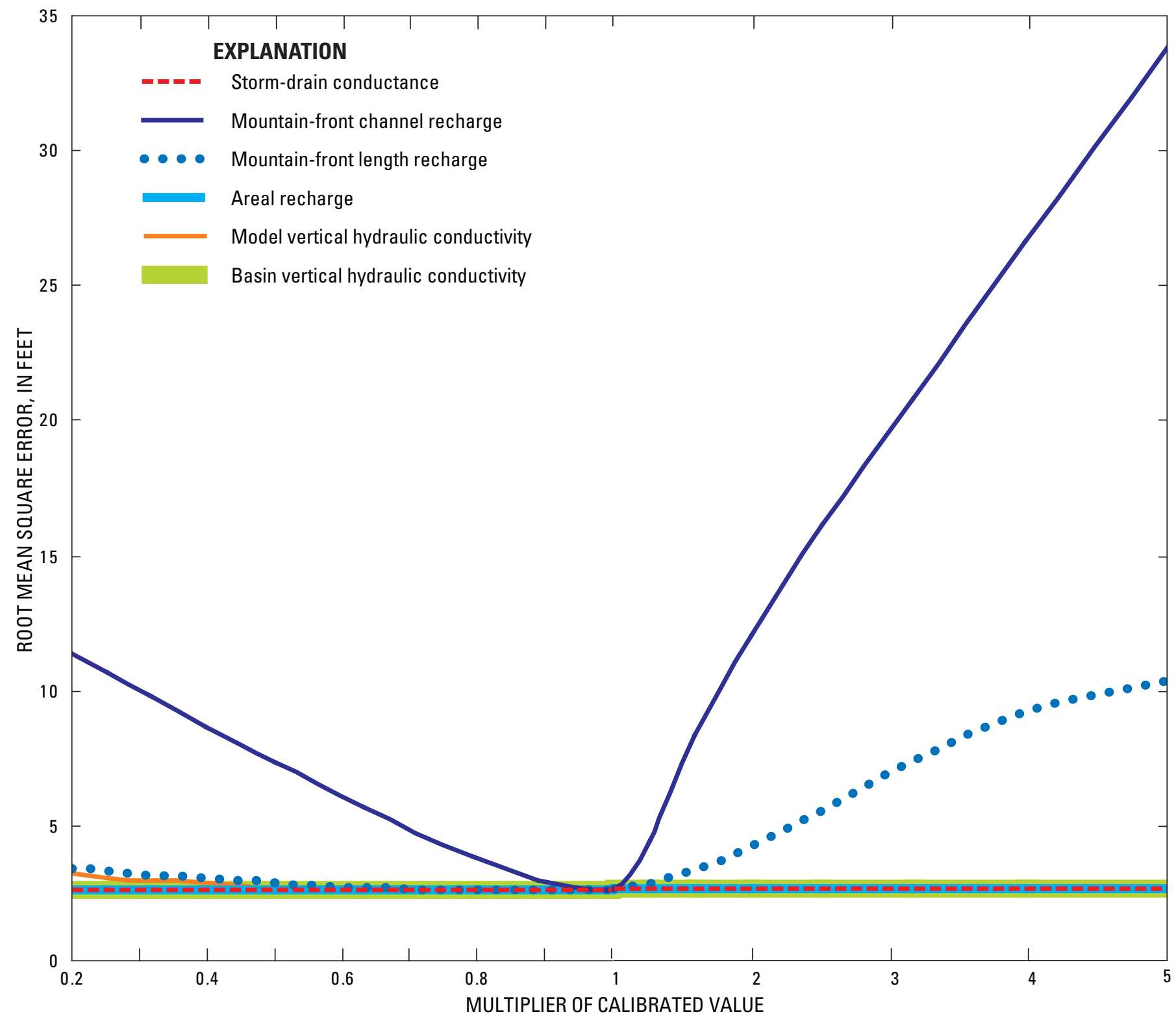

Figure 11. Relative sensitivity of model parameters.

assignment of horizontal hydraulic conductivity across the study area. Simplifying the model to this degree does not invalidate the model results, but should be considered when interpreting the results.

The reliability of ground-water flow models is affected by the choice and accurate representation of the aquifer and related boundary conditions. For purposes of simplification, the upper model boundary (land surface) was simulated as a confined system. The variations in transmissivity with respect to water-level change were trivial and limited error was introduced as a result of this simplification. A one-toone correlation does exist between uncertainties of assigning transmissivity and estimating recharge. For example, a lower hydraulic conductivity, which yields a lower transmissivity, does not require as much water for simulated heads to approach measured heads. In turn, a lower recharge is estimated. Measured water levels in a well cluster in the southern part of the model varied about $2.9 \mathrm{ft}$; therefore the model, assuming homogeneous aquifer properties, was not able to accommodate such a span of water levels in close proximity to each other. Simulated water levels near model boundaries may be less reliable than simulated water levels that are distant from boundaries. Boundary effects are most notable when there are nearby stresses. For instance, PA1 was simulated with a constant-head boundary of 6,234 ft and observed water levels, upgradient and downgradient, were 4-5 ft below that of PA1. Therefore, the model was not able to simulate such a localized field condition. During the construction of PA1, sediments possibly were compacted and resulted in stormwater inflow being semiperched on a less conductive area of aquifer. 


\section{Water Quality in and Near Park Avenue Stormwater Control System}

Median values of $\mathrm{pH}$, specific conductance, dissolved oxygen, and temperature in ground water were 6.4 standard $\mathrm{pH}$ units, $450 \mu \mathrm{S} / \mathrm{cm}, 3.2 \mathrm{mg} / \mathrm{L}$ (34 percent saturation), and $9^{\circ} \mathrm{C}$, respectively. Concentrations of dissolved solids in water samples collected from seven observation wells ranged from $150 \mathrm{mg} / \mathrm{L}$ for site MW194 to $390 \mathrm{mg} / \mathrm{L}$ for site MW197 and the average concentration was $300 \mathrm{mg} / \mathrm{L}$ (igs. 3 and $\underline{4 A}$ ). Concentrations of major ions indicate that upgradient ground water tapped by MW194 is mixed cation (dominated by calcium) bicarbonate type water. Downgradient samples from wells near detention basin PA1 (wells MW196-MW200) have evolved to mixed cation (sodium and calcium)/mixed anion (mostly dominated by chloride) type water (Piper and others, 1953). This evolution is most likely due to the chemistry of recharged stormwater runoff that may be contaminated by deicing road and sidewalk treatments and residual leachate from abandoned septic-tank systems mixing with regional ground water. Decreased concentrations of dissolved oxygen and sulfate in ground-water samples collected downgradient of PA1 may be the result of activity of sulfate-reducing bacteria.

\section{Nutrient Chemistry}

Concentrations of filtered nitrogen were generally largest in ground-water samples collected upgradient of the stormwater control system compared to unfiltered samples of stormwater and filtered ground-water samples collected downgradient of the stormwater control system (fig. 12A). In contrast, concentrations of filtered phosphorus were generally smallest in ground-water samples collected upgradient of the stormwater control system and largest in stormwater (fig. 12B). The maximum concentration of filtered phosphorus was measured in ground water collected downgradient of the stormwater control system (site MW199A; 420 g/L).

Maximum concentrations of unfiltered nitrogen and phosphorus (table 6, fig. 13) are highest among the 22 samples of stormwater inflow to PA1. Maximum values for nitrogen $(7,400 \mu \mathrm{g} / \mathrm{L})$ and phosphorus $(1,500 \mu \mathrm{g} / \mathrm{L})$ were measured in a stormwater sample collected on March 2, 2007, after several inches of snow had accumulated. Air temperature was less than $0^{\circ} \mathrm{C}$ during the week prior to March 2, 2007, and only intermittent snowmelt runoff entered PA1 during this time (fig. 13A). Minimum values of unfiltered nitrogen $(390 \mu \mathrm{g} / \mathrm{L})$ and phosphorus $(79 \mu \mathrm{g} / \mathrm{L}$ ) were measured in a stormwater sample collected on April 18, 2006, after several inches of snow had melted for 6 days prior to sample collection (fig. 13B) and meltwater had flushed the stormwater-collection system. Although the study area typically receives less precipitation than Fallen Leaf Lake (fig. 1), data for the snow pillow at Fallen Leaf Lake, operated by the U.S. Department of Agriculture Natural Resources Conservation Service offered the closest representation of daily snowmelt near the shore of Lake Tahoe (Natural Resources Conservation Service, 2008 [http://www.wcc.nrcs.usda.gov/snow]). Median values of unfiltered nitrogen (2007: 1,300 $\mu \mathrm{g} / \mathrm{L} ; 2006: 870 \mu \mathrm{g} / \mathrm{L}$ ) and phosphorus (2007: $470 \mu \mathrm{g} / \mathrm{L}$; 2006: $240 \mu \mathrm{g} / \mathrm{L}$ ) in stormwater samples were 1.5 and 2.0 times as large in 2007 as median values for 2006. Precipitation in 2006 was about 2.4 times the precipitation in 2007 (fig. 13C). The correlation between lower precipitation and higher nutrient concentrations indicates that increased runoff may dilute nutrient concentrations entering the detention basins. However, the total mass of nutrients delivered by stormwater to the Park Avenue detention basins may be similar from year to year.

Unfiltered concentrations in eight samples of stormwater outflow (seven from site PA1-out and one from PA2; table 6) had the smallest statistical-distribution variables (mean, median, maximum, and minimum) of nitrogen and phosphorus. Comparison of inflow and outflow concentrations indicates that about 55 percent of total nitrogen and 47 percent of total phosphorus may be retained in detention basins due to settling of suspended nutrients. However, filtered concentrations of nitrogen and phosphorus are larger in outflow samples than in detention-basin samples because outflow was sampled during stormwater-runoff events during water years 2006 and 2007 and samples of standing detention basin water were collected only during water year 2007 when precipitation was much less (fig. 13C). The term "water year" means a 12-month period beginning on October 1 and ending on September 30.

The largest mean concentrations of unfiltered nitrogen (table 6; $1,500 \mu \mathrm{g} / \mathrm{L}$ ) and phosphorus (570 $\mu \mathrm{g} / \mathrm{L}$ ) in stormwater samples are for seven samples of standing detention basin water from PA1, but concentrations in filtered samples collected at the same time had the smallest mean concentrations of nitrate plus nitrite nitrogen $(110 \mu \mathrm{g} / \mathrm{L})$, ammonium nitrogen (17 $\mu \mathrm{g} / \mathrm{L})$, and phosphorus ( $49 \mu \mathrm{g} / \mathrm{L})$. Relatively small concentrations of filtered nitrate plus nitrite, ammonium, and phosphorus indicate that these more biologically available nutrients are assimilated during photosynthesis by aquatic plants in PA1.

Ninety-five samples of ground water from 11 observation wells had the largest statistical-distribution variables (mean, median, maximum, and minimum) of filtered nitrogen concentrations and, except for the anomalous maximum concentration $(420 \mu \mathrm{g} / \mathrm{L})$, had the smallest distribution of phosphorus concentrations for all filtered water samples. 
(28)

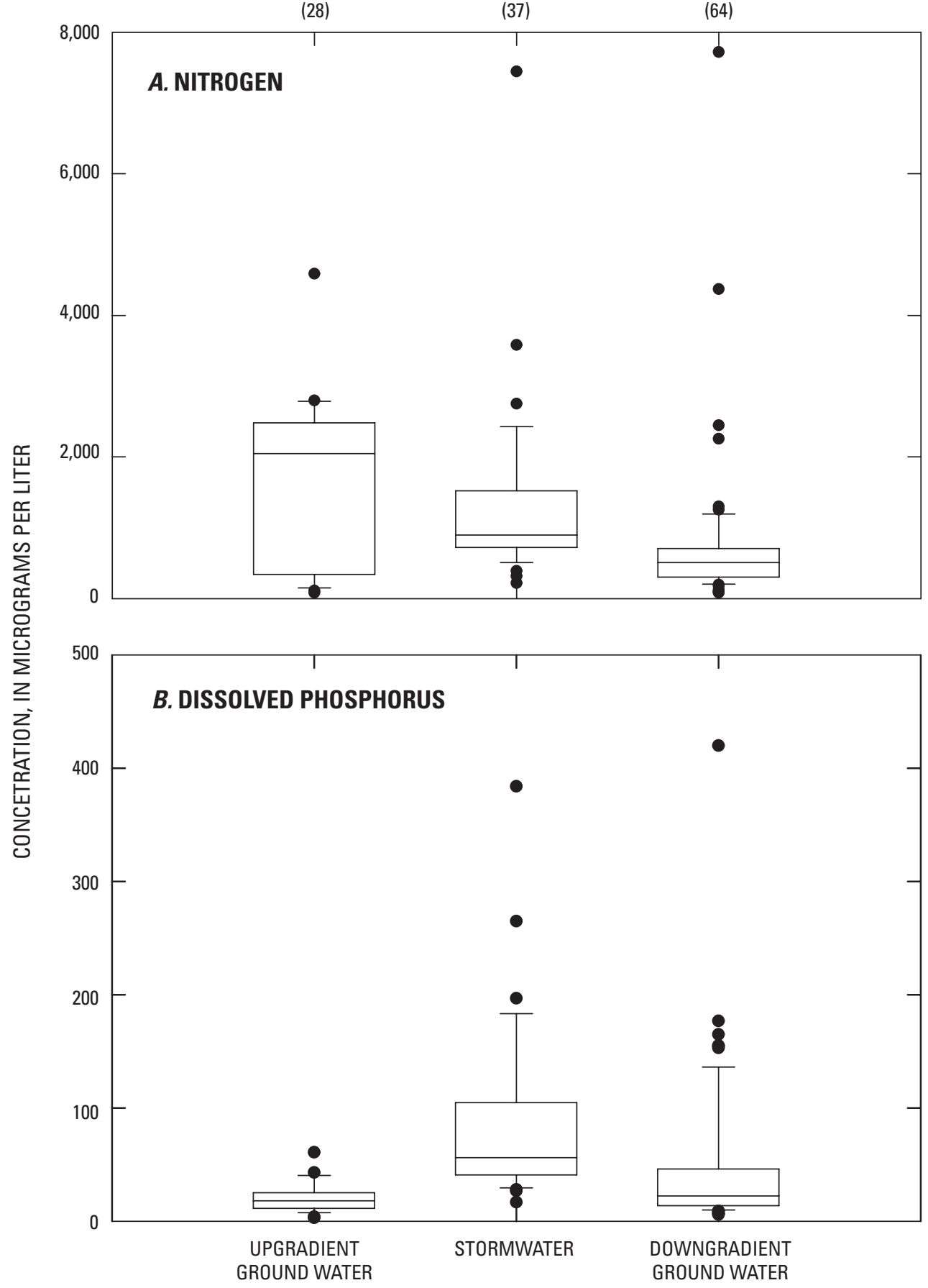

EXPLANATION

(37) Number of data points used in construction of schematic plot<smiles>[3H]CCC1CCCC1</smiles>

75th Percentile

\begin{tabular}{l|l} 
Median & Semiquartile
\end{tabular} Range 25th Percentile

Vertical Lines-Lines from rectangle extend to the limit of the data

- Outside Value - Values are more than 1.0 times the semiquartile range from the top or bottom of the rectangle

Figure 12. Statistical distribution of nitrogen and phosphorus concentrations in water samples grouped by source, Park Avenue detention basin, South Lake Tahoe, California. 
Table 6. Statistical summary of nitrogen and phosphorus concentrations in water samples grouped by source, Park Avenue stormwater collection and detention system, South Lake Tahoe, California, water years 2006-07.

[The term "water year" means a 12-month period beginning October 1 and ending September 30. Sample collection sites described in table 1. Abbreviation: mg/L, microgram per liter; PA1, Park Avenue basin 1; n, sample count. Symbol: -, data not collected]

\begin{tabular}{|c|c|c|c|c|}
\hline \multirow{2}{*}{ Statistic } & \multicolumn{2}{|c|}{$\begin{array}{c}\text { Nitrogen } \\
\text { (mg/L) }\end{array}$} & \multicolumn{2}{|c|}{$\begin{array}{l}\text { Phosphorus } \\
\text { (mg/L) }\end{array}$} \\
\hline & Unfiltered & Filtered & Unfiltered & Filtered \\
\hline \multicolumn{5}{|c|}{ Stormwater inflow (PA1_inletA and PA1_inletB [n=22]) } \\
\hline Mean & 1,500 & - & 380 & 94 \\
\hline Minimum & 390 & - & 79 & 30 \\
\hline Median & 1,200 & - & 270 & 60 \\
\hline Maximum & 7,400 & - & 1,500 & 380 \\
\hline \multicolumn{5}{|c|}{ Detention-basin water at PA1_stage $(n=7)$} \\
\hline Mean & 1,500 & - & 570 & 48 \\
\hline Minimum & 530 & - & 69 & 17 \\
\hline Median & 890 & - & 380 & 43 \\
\hline Maximum & 3,600 & - & 1,200 & 92 \\
\hline \multicolumn{5}{|c|}{ Stormwater outflow from PA1_out $(n=7)$} \\
\hline Mean & 720 & - & 200 & 99 \\
\hline Minimum & 220 & - & 66 & 27 \\
\hline Median & 780 & - & 240 & 80 \\
\hline Maximum & 970 & - & 310 & 260 \\
\hline \multicolumn{5}{|c|}{ Ground water at all 11 observation wells ( $n=95$ ) } \\
\hline Mean & - & 1,100 & - & 39 \\
\hline Minimum & - & 82 & - & 3 \\
\hline Median & - & 580 & - & 20 \\
\hline Maximum & - & 7,700 & - & 420 \\
\hline \multicolumn{5}{|c|}{ Ground water upgradient of PA1 $(n=28)$} \\
\hline Mean & - & 1,700 & - & 20 \\
\hline Minimum & - & 82 & - & 3 \\
\hline Median & - & 2,000 & - & 18 \\
\hline Maximum & - & 4,600 & - & 61 \\
\hline \multicolumn{5}{|c|}{ Ground water downgradient of PA1 $(n=64)$} \\
\hline Mean & - & 740 & - & 48 \\
\hline Minimum & - & 82 & - & 6 \\
\hline Median & - & 510 & - & 23 \\
\hline Maximum & - & 7,700 & - & 420 \\
\hline \multicolumn{5}{|c|}{ All stormwater samples $(n=37)$} \\
\hline Mean & 1,300 & - & 380 & 86 \\
\hline Minimum & 220 & - & 66 & 17 \\
\hline Median & 900 & - & 250 & 56 \\
\hline Maximum & 7,400 & - & 1,500 & 380 \\
\hline
\end{tabular}



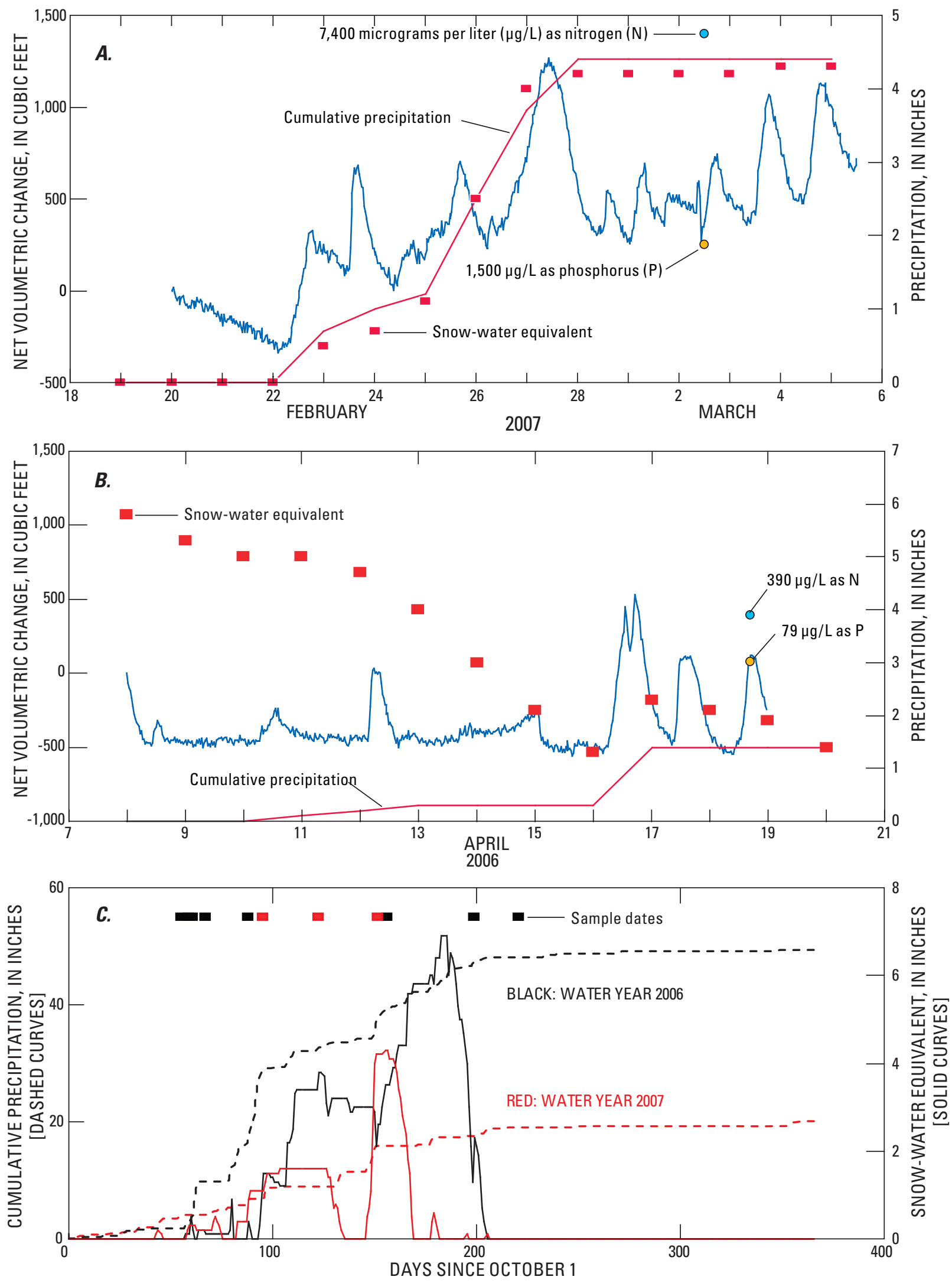

Figure 13. Relations among net change in the volume of stormwater accumulated in PA1, precipitation, and unfiltered concentrations of nitrogen and phosphorus in sampled stormwater inflow, Park Avenue detention basin, South Lake Tahoe, California. 
Concentrations of filtered nitrogen and phosphorus in ground water averaged 1,100 and $39 \mu \mathrm{g} / \mathrm{L}$, respectively. Nitrogen ranged from 82 to $7,700 \mu \mathrm{g} / \mathrm{L}$ and phosphorus ranged from 3 to $420 \mu \mathrm{g} / \mathrm{L}$. Nitrogen concentrations measured in individual wells varied $380 \mu \mathrm{g} / \mathrm{L}(410-790 \mu \mathrm{g} / \mathrm{L})$ for samples from site MW198A to 4,200 $\mu \mathrm{g} / \mathrm{L}(200-4,400 \mu \mathrm{g} / \mathrm{L})$ for samples from site MW201A (figs. 3 and $\underline{14 A}$ ). The maximum nitrogen concentration from site MW201A was measured in a sample collected November 7, 2005. Phosphorus concentrations measured in individual wells varied $9 \mu \mathrm{g} / \mathrm{L}(13-22 \mu \mathrm{g} / \mathrm{L})$ for samples from site MW198B to $410 \mu \mathrm{g} / \mathrm{L}$ (7-420 $\mu \mathrm{g} / \mathrm{L})$ from site MW199A (ig. 14B). The maximum phosphorus concentration was measured in a sample collected on May 9, 2006, from site MW199A. During well purging of almost 16 gal, the discharge water frothed as if it contained detergent or other surfactants, such as naturally occurring dissolved organic carbon. One other filtered sample from site MW199A had phosphorus concentration greater than $100 \mu \mathrm{g} / \mathrm{L}$ and six of the nine samples were $20 \mu \mathrm{g} / \mathrm{L}$ or less.

\section{Ratios of Oxygen and Hydrogen Stable Isotopes}

The isotopic composition of water, expressed as oxygen-18 relative to oxygen- $16\left({ }^{18} \mathrm{O} /{ }^{16} \mathrm{O}\right)$ and deuterium relative to hydrogen- $1\left({ }^{2} \mathrm{H} /{ }^{1} \mathrm{H}\right)$, of local ground water was shown to be different from that of Lake Tahoe due to evaporative fractionation of lakewater that has an estimated residence time of 700 years (Thodal, 1997). By convention, each ratio is related mathematically to the comparable ratio for an international reference standard known as the Vienna Standard Mean Ocean Water (VSMOW) and expressed as "delta oxygen-18" $\left(\delta^{18} \mathrm{O}\right)$ and "delta deuterium" $\left(\delta^{2} \mathrm{H}\right)$; the units of measure are parts per thousand (abbreviated permil). A negative delta value indicates that the sample water is lighter isotopically than the standard (depleted). Evaporation preferentially removes the lighter isotopes $\left({ }^{16} \mathrm{O}\right.$ and $\left.{ }^{1} \mathrm{H}\right)$ as water vapor and the heavier isotopes $\left({ }^{18} \mathrm{O}\right.$ and $\left.{ }^{2} \mathrm{H}\right)$ remain in the liquid water. Figure 15 shows the relation of stable-isotope values for samples from Lake Tahoe, shallow ground water near the Park Avenue stormwater collection system, and two samples of interstitial water that fall along a linear mixing line $\left(\delta^{2} \mathrm{H}=26.19+\left(5.59\left(\delta^{18} \mathrm{O}\right)\right)\right.$ between lakewater and ground water. The meteoric water line $\left(\delta^{2} \mathrm{H}=26.19+\left(5.59\left(\delta^{18} \mathrm{O}\right)\right)\right.$; Craig, 1961) also is shown.

Eight water samples were collected from five nearshore locations in Lake Tahoe, July 26 and August 2, 2007, that averaged -5.2 permil $\delta^{18} \mathrm{O}\left(-5.6\right.$ to -5.1 permil $\left.\delta^{18} \mathrm{O}\right)$ and
-55.9 permil $\delta^{2} \mathrm{H}\left(-59.0\right.$ to -54.4 permil $\left.\delta^{2} \mathrm{H}\right)$. One water sample collected from Lake Tahoe in 1980 was -5 permil $\delta^{18} \mathrm{O}$ and -56 permil $\delta^{2} \mathrm{H}$. The five samples collected from the lakebed/lakewater interface averaged -5.2 permil $\delta^{18} \mathrm{O}$ and -55.9 permil $\delta^{2} \mathrm{H}$ compared to three samples collected $1 \mathrm{ft}$ beneath lakewater surface that averaged -5.1 permil $\delta^{18} \mathrm{O}$ and -54.8 permil $\delta^{2} \mathrm{H}$. The isotopic composition of 11 shallow ground-water samples averaged -13.94 permil $\delta^{18} \mathrm{O}(-15.05$ to -12.70 permil $\left.\delta^{18} \mathrm{O}\right)$ and -104.0 permil $\delta^{2} \mathrm{H}(-110.4$ to -97.6 permil $\delta^{2} \mathrm{H}$ ) and are comparable to 32 samples of ground water collected from wells and a spring in the Lake Tahoe Basin in 1990 that averaged -14 permil $\delta^{18} \mathrm{O}$ and -104 permil $\delta^{2} \mathrm{H}$ (Thodal, 1997). Isotopic compositions of two samples of interstitial water, collected $0.8 \mathrm{ft}$ beneath the lakebed using a 0.5 -in. diameter minipeizometer, were -13.85 permil $\delta^{18} \mathrm{O} ;-102.5$ permil $\delta^{2} \mathrm{H}$ and -9.76 permil $\delta^{18} \mathrm{O}$; -80.8 permil $\delta^{2} \mathrm{H}$. Both interstitial-water samples fall on a linear mixing line between lakewater and ground water, with the isotopic signature for the interstitial water sample collected from site L3 (ig. 3) falling in the middle of values measured in wellwater samples (ig. 15).

\section{Chemical Composition of Bottom-Sediment Samples}

One $2 \mathrm{ft}$ core of bottom sediment was collected from PA1 (fig. 4A; site PA1) and divided into two samples for laboratory analyses to assess pollutant retention by the infiltration basin (tables B1 and B2). Laboratory determinations of selected chemicals of potential concern associated with urban stormwater runoff included chromium, copper, lead, mercury, nickel, organic carbon, phosphorus, and zinc. Sediment samples also were analyzed for selected polycyclic aromatic hydrocarbons (PAHs). These compounds are found in petroleum products and tar, and are produced by combustion of petroleum as well as by forest fires and wood-burning stoves (Smith and others, 1988, p. 64-67). Comparison of concentrations in surface sediment to those in sediment collected from depth provides a qualitative evaluation of the ability of the detention-basin sediment to retain contaminants, the potential for adverse environmental effects to wet basin ecology, and economic and regulatory considerations for contaminated-sediment disposal. Selected published sediment toxicity screening values also are provided for comparison with data from PA1 (table 7). 


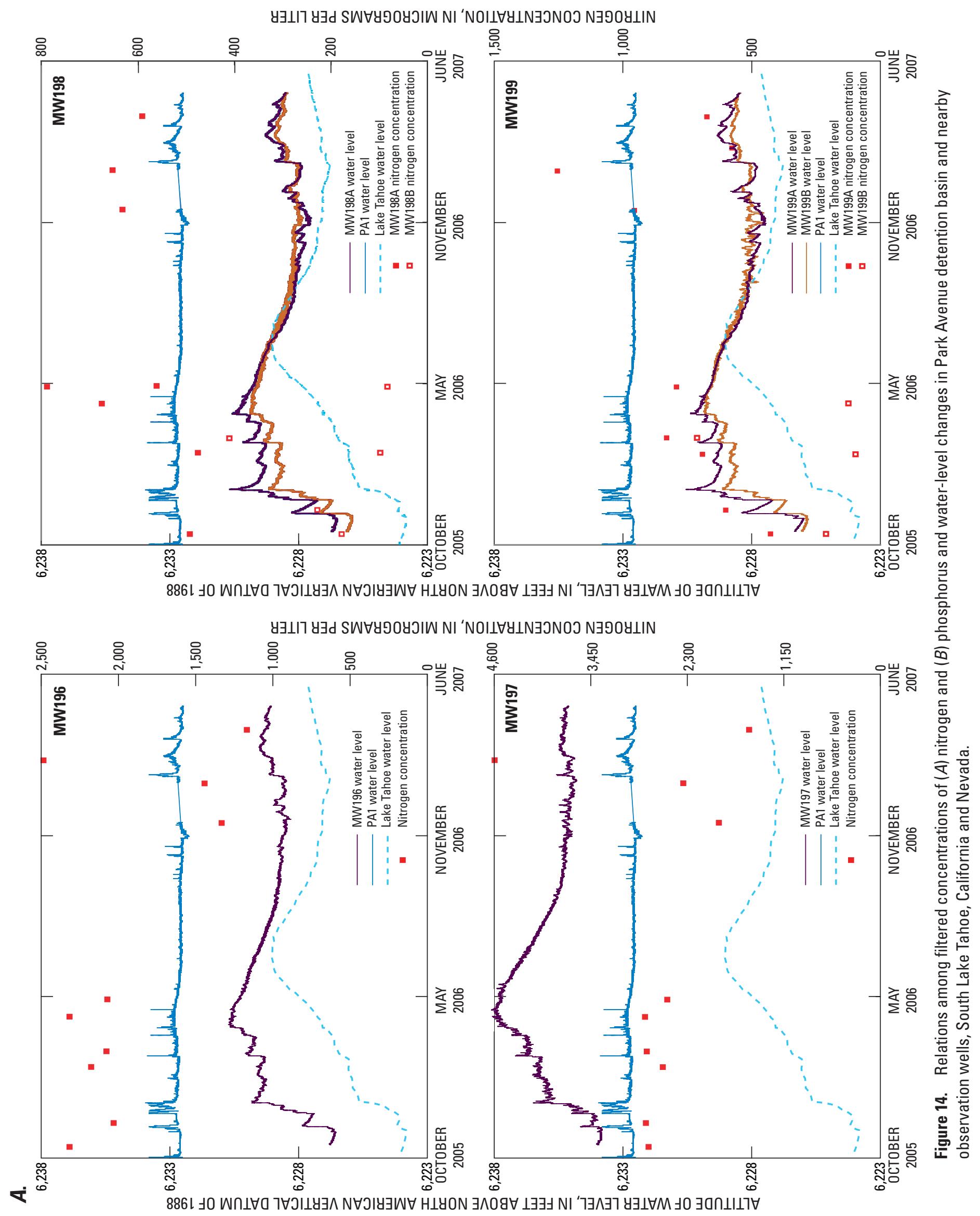




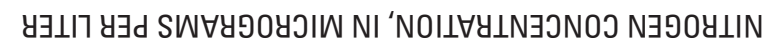
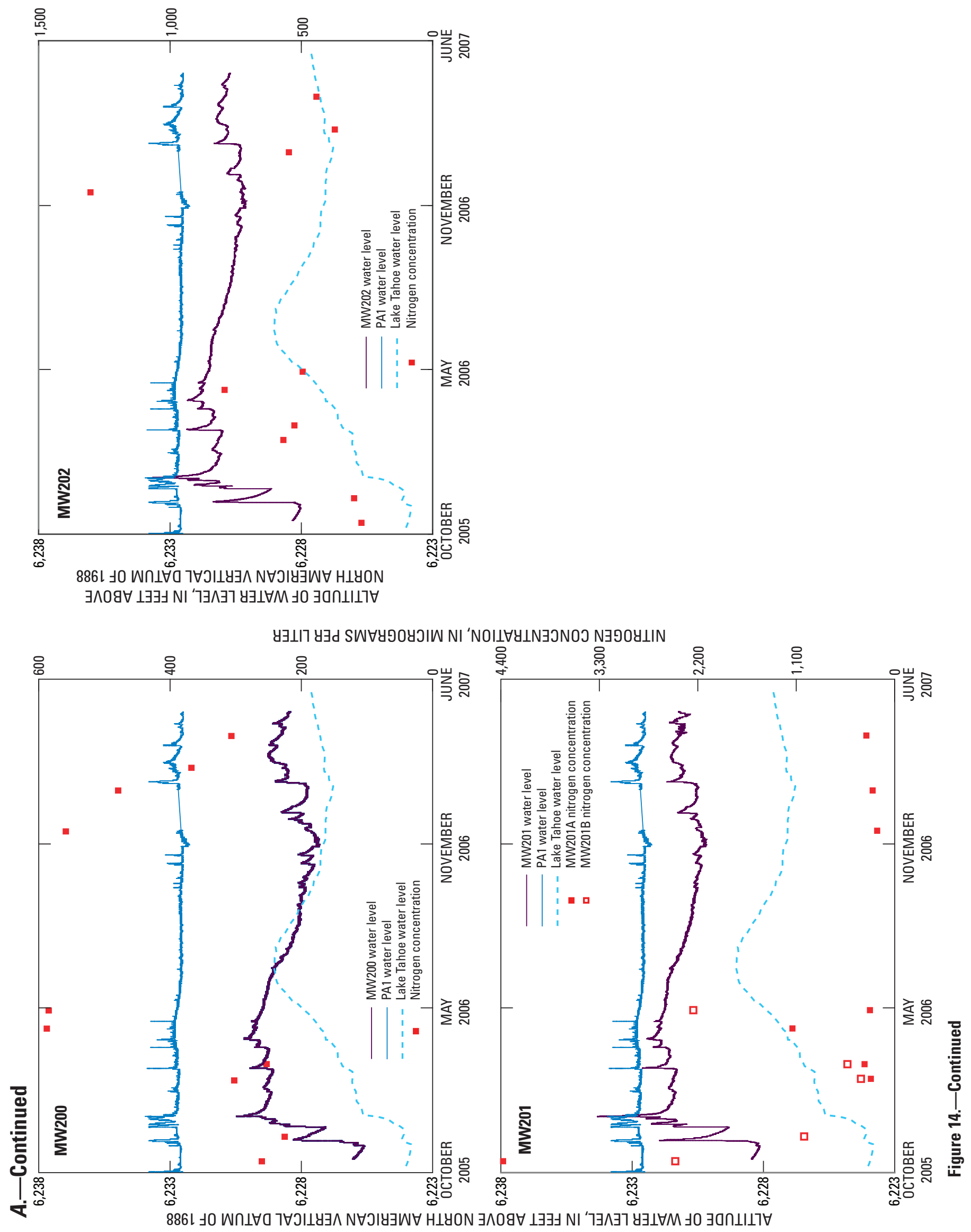


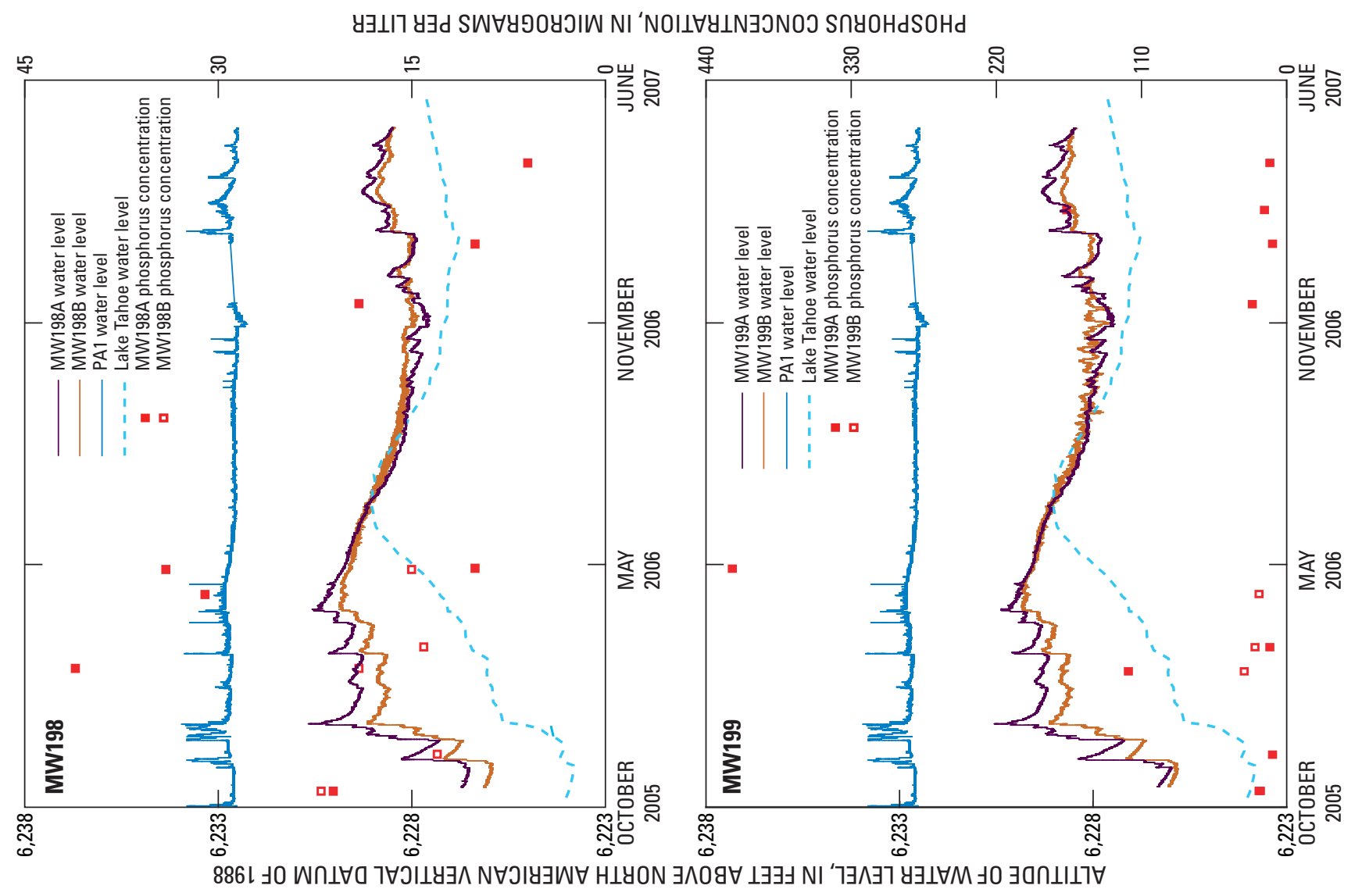

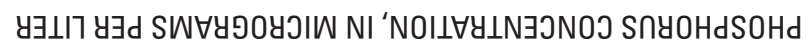

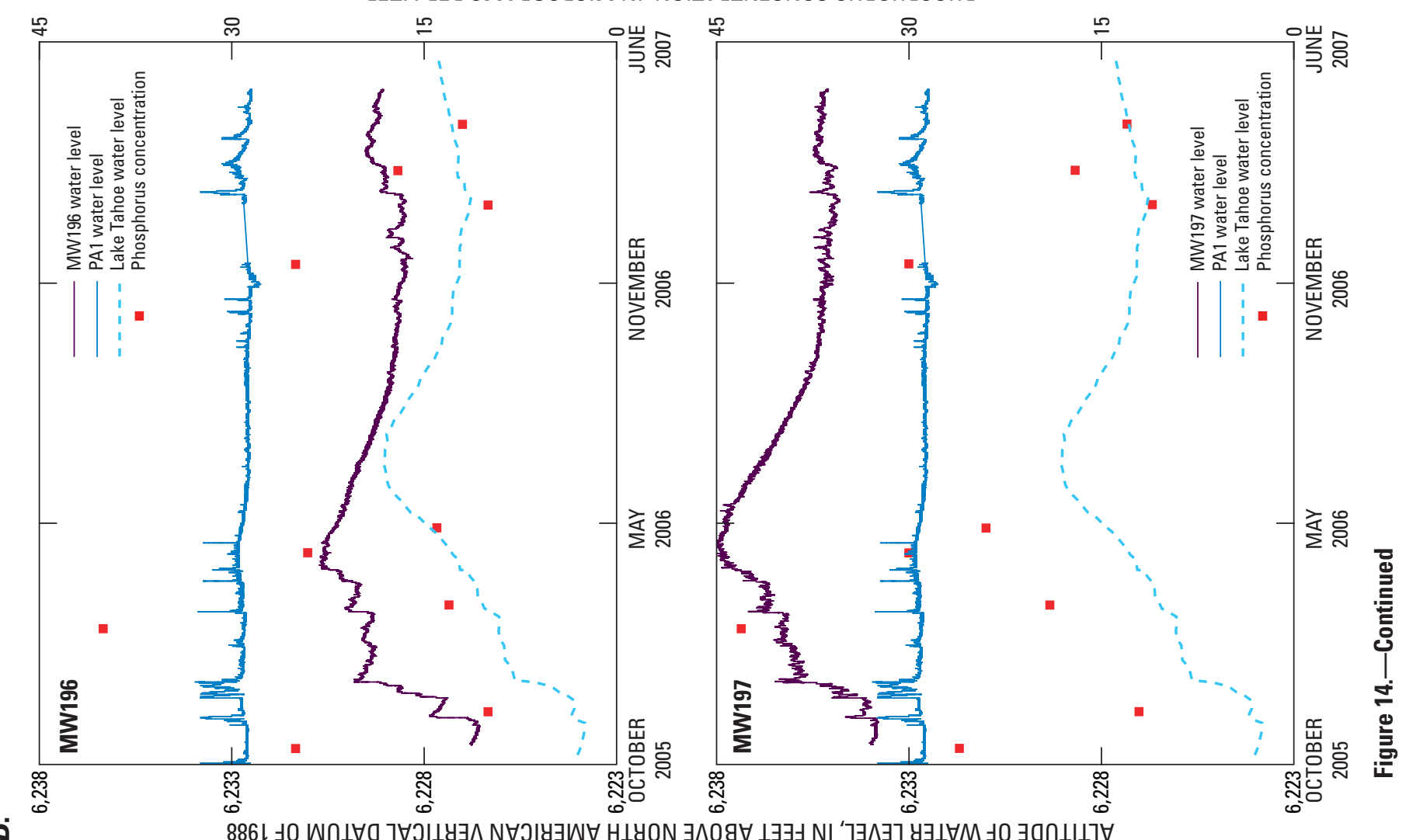




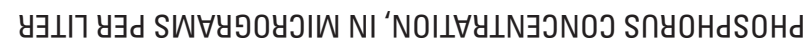

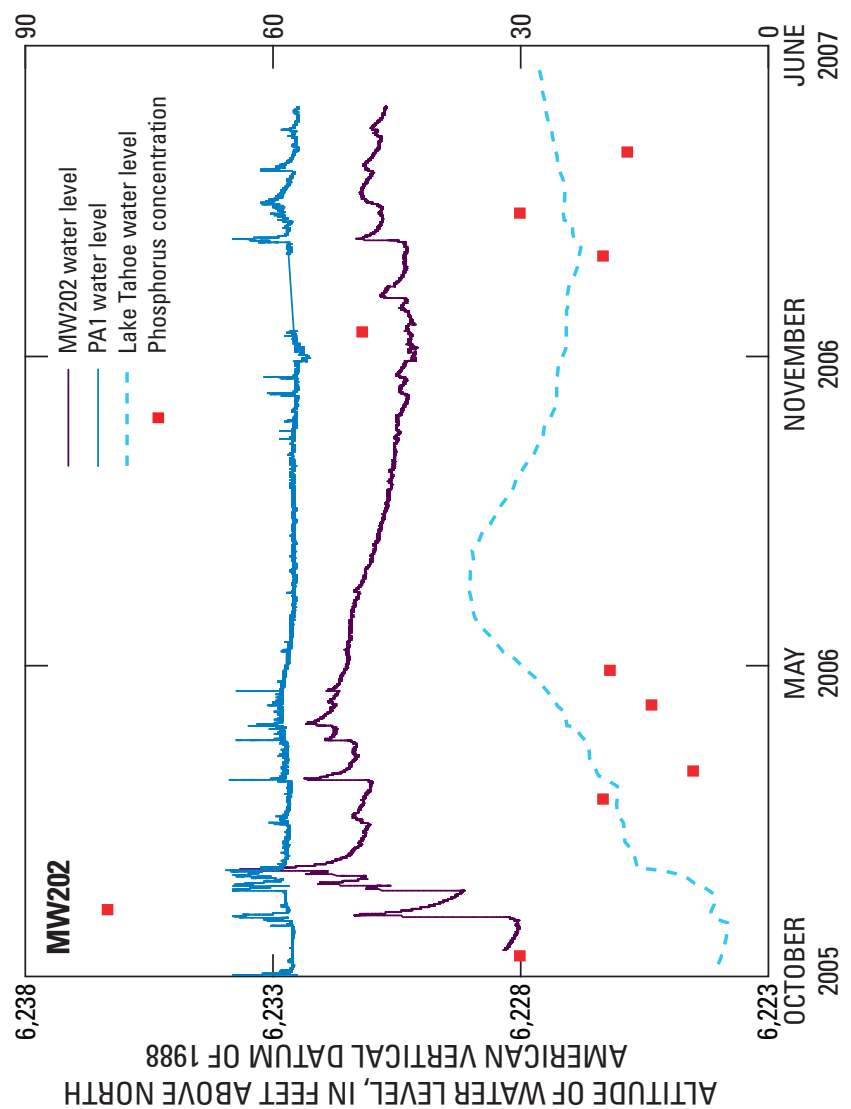

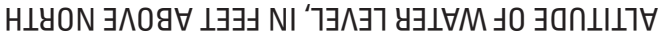

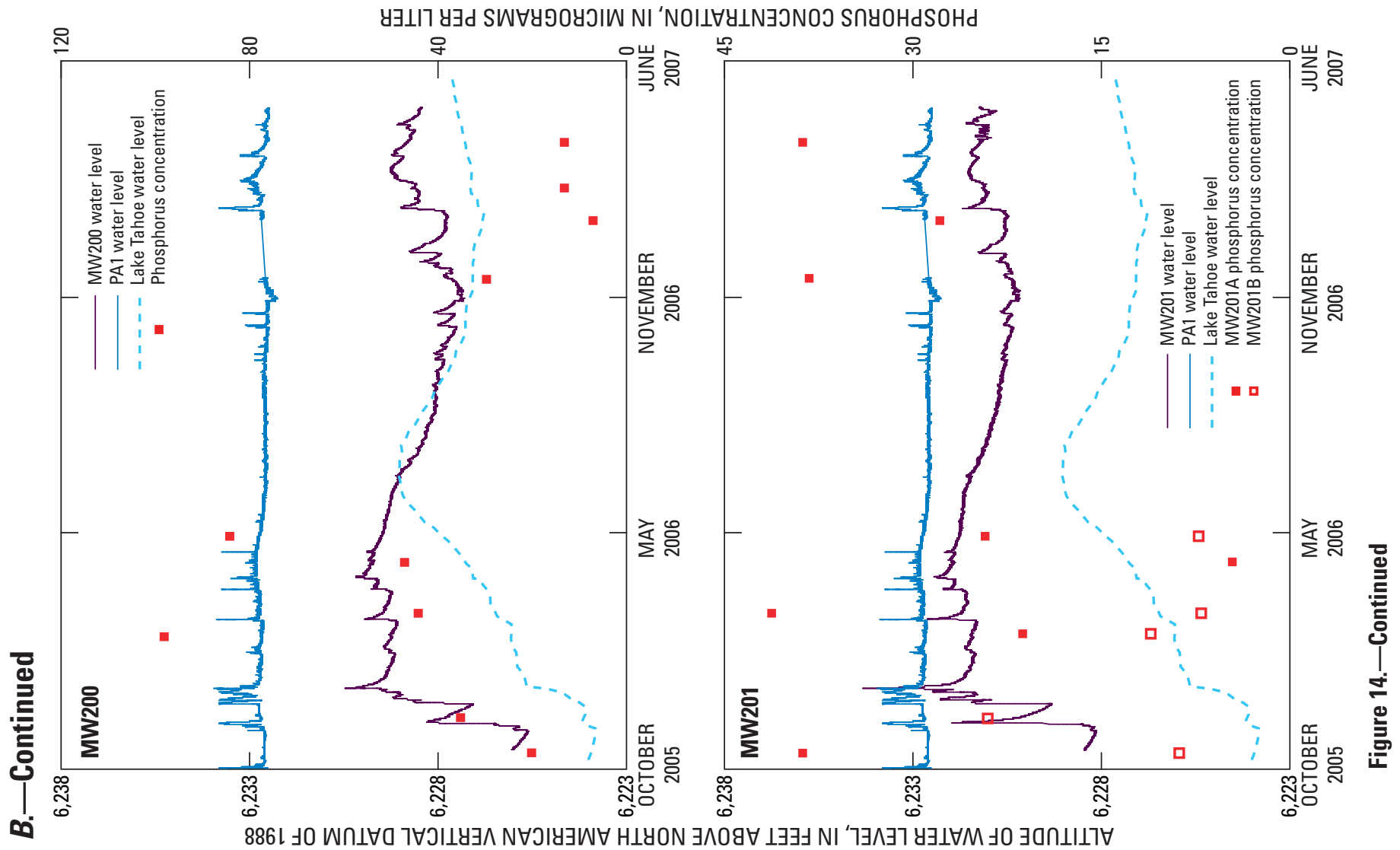




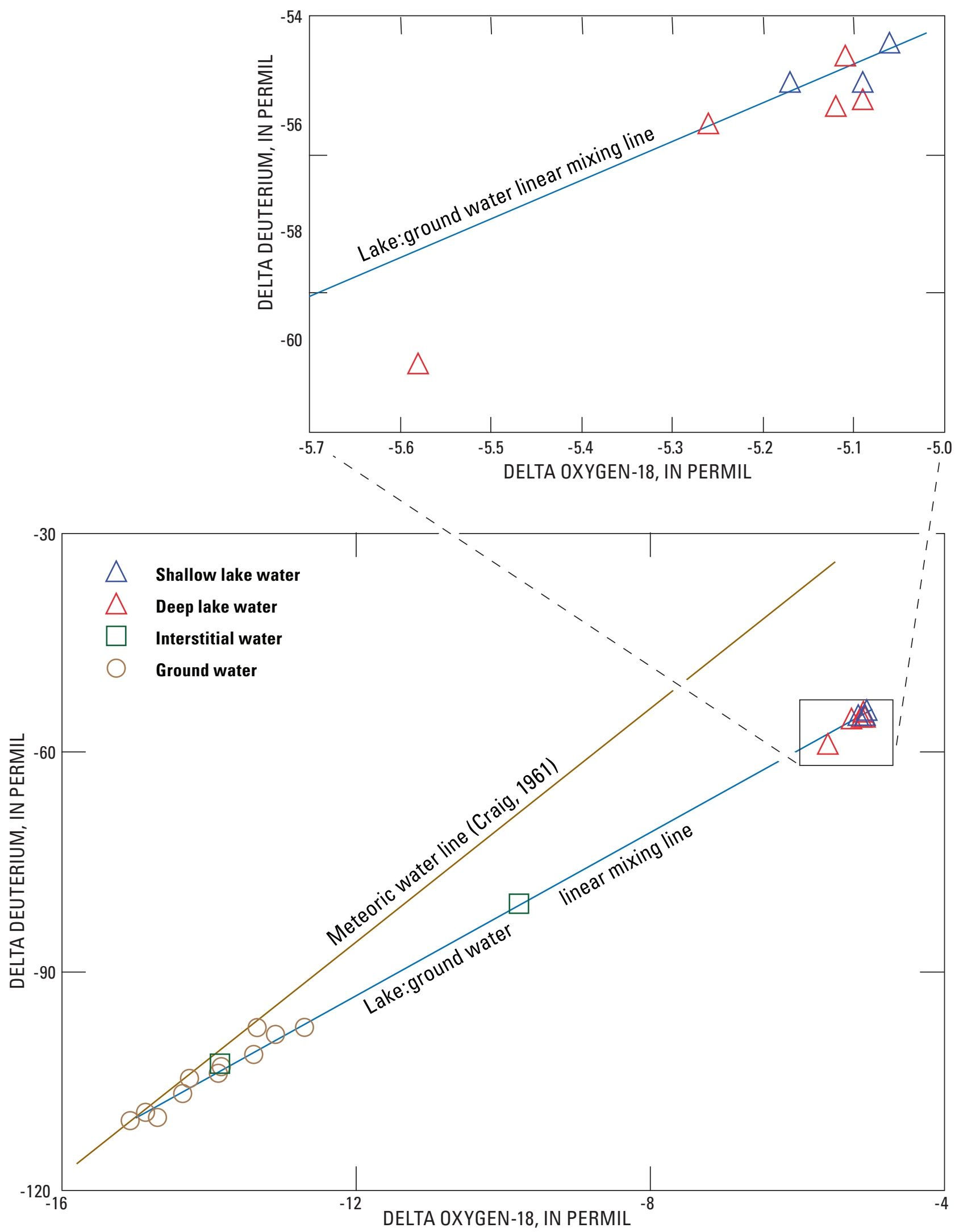

Figure 15. Relation between stable isotopes of hydrogen and oxygen in lake-water and ground-water samples collected near Park Avenue stormwater collection system, South Lake Tahoe California, 2005-07. 
Table 7. Concentrations of selected chemicals of potential concern in bottom sediment collected on August 31, 2005 from Park Avenue detention basin 1, South Lake Tahoe, California, and sediment toxicity screening values for protection of benthic aquatic life.

[Probable effect level: From Smith and others, 1996. Effective range: From Long and Morgan, 1991. Severe effect level: From Persaud and others, 1993. Consensus-based probable effect concentration: From Ingersoll and others, 2000. Abbreviations: $\mu \mathrm{g} / \mathrm{g}$, microgram per gram; ft, foot; <, less than]

\begin{tabular}{|c|c|c|c|c|c|c|}
\hline \multirow{2}{*}{ Constituent } & \multicolumn{2}{|c|}{$\begin{array}{c}\text { Sediment concentration } \\
(\mu \mathrm{g} / \mathrm{g})\end{array}$} & \multirow{2}{*}{$\begin{array}{c}\text { Probable } \\
\text { effect level } \\
(\mu g / g)\end{array}$} & \multirow{2}{*}{$\begin{array}{c}\text { Effect range, } \\
\text { median } \\
(\mu \mathrm{g} / \mathrm{g})\end{array}$} & \multirow{2}{*}{$\begin{array}{c}\text { Severe } \\
\text { effect level } \\
(\mu \mathrm{g} / \mathrm{g})\end{array}$} & \multirow{2}{*}{$\begin{array}{c}\text { Consensus-based } \\
\text { probable effect } \\
\text { concentration } \\
(\mu \mathrm{g} / \mathrm{g})\end{array}$} \\
\hline & $\begin{array}{c}0-0.2 \mathrm{ft} \\
\text { depth sample }\end{array}$ & $\begin{array}{c}1.5-1.7 \mathrm{ft} \\
\text { depth sample }\end{array}$ & & & & \\
\hline Cadmium & 0.62 & 0.22 & 3.53 & 9 & 10 & 4.98 \\
\hline Copper & 120 & 38 & 197 & 390 & 110 & 149 \\
\hline Lead & 54 & 19 & 91.3 & 110 & 250 & 128 \\
\hline Mercury & 0.12 & .04 & 0.486 & 1.3 & 2 & 1.06 \\
\hline Nickel & 27 & 12 & 36 & 50 & 75 & 48.6 \\
\hline Zinc & 480 & 79 & 315 & 270 & 820 & 459 \\
\hline Anthracene & 0.3 & $<0.01$ & - & 0.96 & 3.7 & 0.845 \\
\hline Benz[a]Anthracene & 0.4 & $<0.01$ & 0.385 & 1.6 & 1.48 & 1.05 \\
\hline Benzo[e]Perylene & 0.6 & $<0.01$ & - & - & - & - \\
\hline Benzo[g,h,i]Perylene & 0.4 & $<0.01$ & - & - & - & - \\
\hline Chrysene & 0.5 & $<0.01$ & 0.862 & 2.8 & 4.6 & 1.29 \\
\hline 1,6-dimethyl Naphthalene & 0.2 & $<0.01$ & - & - & - & - \\
\hline 2,6-dimethyl Naphthalene & 0.2 & $<0.01$ & - & - & - & - \\
\hline 2-ethyl Naphthalene & 0.1 & $<0.01$ & - & - & - & - \\
\hline Fluoranthene & 1.0 & $<0.01$ & 2.355 & 3.6 & 10.2 & 2.23 \\
\hline 4,5-methylene Phenanthrene & 0.2 & $<0.01$ & - & - & - & - \\
\hline 1-methyl Phenanthrene & 0.2 & $<0.01$ & - & - & - & - \\
\hline Perylene & 0.4 & $<0.01$ & - & - & - & - \\
\hline Phenanthrene & 0.8 & $<0.01$ & 0.515 & 1.38 & 9.5 & 1.17 \\
\hline Pyrene & 1.0 & $<0.01$ & 0.875 & 2.2 & 8.5 & 1.52 \\
\hline 2,3,6-trimethyl Naphthalene & 0.2 & $<0.01$ & - & - & - & - \\
\hline
\end{tabular}

Concentrations of organic carbon, cadmium, copper, lead, mercury, nickel, phosphorus, sulfur, and zinc in the surface sample are all at least twice as large as concentrations in the deeper sample $(6.4,2.8,3.2,2.8,3,2.2,3.2$, more than 7.2 and 6.1 times, respectively), but chromium in the surface sample was only 1.1 times more than the deeper sample. Cadmium, copper, lead, nickel, and zinc are metals used in the fabrication of tires and brake linings (Hjortenkrans and others, 2007, p. 5224-5225). Other studies in the Lake Tahoe basin also demonstrate increased concentrations of metals in shallower sediments compared with deeper samples. Concentrations of lead and mercury in sediment core-samples collected from Lake Tahoe (Heyvaert and others, 2000) were 6 and 5 times larger, respectively, in samples estimated to have been deposited in the mid- $20^{\text {th }}$ century compared to sediment deposited prior to 1850, indicating regional atmospheric sources of these contaminants. Concentrations of 28 PAHs were all less than laboratory reporting limits in the deeper sample, but 15 compounds were quantified and the concentration of an additional compound, acenaphthalene, was estimated in the surficial sample.
No constituents measured in the deeper (1.5-1.7 ft) bottom-sediment sample exceeded concentrations for chemicals of potential concern for protection of benthic aquatic life, but concentrations in the surface sample $(0-0.2 \mathrm{ft})$ exceeded the severe effect level for copper and the median effect, probable effect, and consensus-based probable effect levels for zinc. Probable effect levels also were exceeded for benz[a]anthracene $(0.4 \mu \mathrm{g} / \mathrm{g})$, phenanthrene $(0.8 \mu \mathrm{g} / \mathrm{g})$, and pyrene $(1.0 \mu \mathrm{g} / \mathrm{g}$; table 7$)$ in the surficial bottom sediment sample.

\section{Processes Affecting Water Quality in and Near Detention Basins}

Settling of suspended particles, accumulation of chemicals of potential concern, and biological assimilation of dissolved nutrients are the primary stormwater treatments achieved by the Park Avenue detention basins. Suspended particulates may include suspended micro-organisms (algae, bacteria, and fungi), organic detritus, and suspended inorganic sediment particles to which ammonium, phosphate, metals, 
and hydrophobic organic compounds have sorbed. Dissolved nutrients are available for biological assimilation by algae, bacteria, fungi, and aquatic vascular plants. Additionally, bacteria and fungi can decompose particulates to derive energy from carbon and assimilate nutrients.

Contributions of the species of phosphorus (suspended phosphorus and filtered orthophosphate and hydrolyzable phosphorus) relative to total concentrations indicate that most of the phosphorus is associated with particles that are larger than $0.45 \mu \mathrm{m}$ (nominal pore size of cartridge filter; fig. 16). Suspended phosphorus, estimated as the difference between unfiltered and filtered phosphorus values, had mean concentrations that averaged 67 percent of the total phosphorus (range: 26-94 percent). Suspended phosphorus in samples from detention basin PA1 averaged 86 percent of total phosphorus (range: 71-96 percent) and outflow samples averaged 55 percent of total phosphorus (range: 16-74 percent). The phosphorus concentration $(1,400 \mu \mathrm{g} / \mathrm{g})$ in the surface sample of bottom sediment supports the observation that about half of unfiltered phosphorus in stormwater inflow to detention basin PA1 settles out and is retained by the stormwater-control system. However, assuming that the phosphorus concentration in one sample of bottom sediment is representative of sediment throughout detention basin PA1, about $50 \mathrm{lb}$ of phosphorus has accumulated in the top $0.2 \mathrm{ft}$ of sediment in PA1 while almost $200 \mathrm{lb}$ of phosphorus is estimated to be associated with inflow to PA1.

Suspended plus organic nitrogen in six samples from detention basin PA1 were 96 percent of total nitrogen (range: 91-99 percent) but suspended plus organic nitrogen in seven outflow samples averaged 73 percent of total nitrogen (range: 54-90 percent). However, organic nitrogen was not determined in filtered stormwater samples. Suspended plus organic nitrogen, estimated by subtracting mean filtered concentrations of ammonium and nitrate plus nitrite from total nitrogen, measured in 22 samples of inflowing stormwater averaged almost 78 percent of the total nitrogen (range: 8-97 percent). Concentrations of filtered nitrogen and phosphorus probably are decreased due to photosynthesis and assimilation by suspended biomass (algae, bacteria, and fungi) as well as by attached aquatic vegetation. However, because concentrations of filtered organic nitrogen in stormwater samples were not determined, it is not known how much of the total nitrogen was suspended nitrogen and how much was filterable organic nitrogen.

Concentrations of filtered nitrogen $(440 \mu \mathrm{g} / \mathrm{L})$ and phosphorus $(20 \mu \mathrm{g} / \mathrm{L})$ in ground-water samples from site MW194 (upgradient of most development) predominately are organic nitrogen and hydrolyzable phosphorus (fig. 15). The mean concentration of nitrogen is larger than values for samples from three other wells and phosphorus concentration is larger than values for two other wells. Nutrient-enriched surface runoff in the Lake Tahoe basin has been attributed to accumulation of forest litter due to fire suppression (Miller and others, 2005). Recharge from an intermittent stream near this site may be the source of nitrogen and phosphorus in samples from this well.

Sites MW196 and MW197 are upgradient of detention basin PA1 and have the two largest mean concentrations of filtered nitrogen (2,000 $\mu \mathrm{g} / \mathrm{L}$ and 2,700 $\mu \mathrm{g} / \mathrm{L}$, respectively) that are more than 90 percent nitrate plus nitrite. This indicates that nitrate contamination of the regional shallow aquifer, possibly by past wastewater-disposal practices, continues to persist since its early recognition in low-flow stream samples (Perkins and others, 1975) and ground-water monitoring results (Thodal, 1997). Filtered concentrations of phosphorus $(19 \mu \mathrm{g} / \mathrm{L}$ and $23 \mu \mathrm{g} / \mathrm{L})$ are comparable to concentrations for site MW194, with hydrolyzable phosphorus slightly more dominant.

Filtered nitrogen concentrations in samples from sites immediately downgradient of detention basin PA1 average much less than concentrations in the two upgradient sites, with ammonium and organic nitrogen accounting for 84-99 percent of the average filtered nitrogen concentrations. This indicates that a recharge mound beneath detention basin PA1 has displaced the regional ground water with infiltrated stormwater with a lower mean concentration of nitrate $(44 \mu \mathrm{g} / \mathrm{L})$ that also has diluted the high nitrate concentrations and introduced elevated concentrations of ammonium and organic nitrogen. Mean concentrations of filtered phosphorus for the four downgradient wells (17-24 $\mu \mathrm{g} / \mathrm{L}$ ) are comparable to the concentrations in upgradient wells $(19-23 \mu \mathrm{g} / \mathrm{L})$ with hydrolyzable phosphorus contributing more than 70 percent of the filtered phosphorus. However, the mean phosphorus concentration for site MW199A (fig. 3) was $72 \mu \mathrm{g} / \mathrm{L}$ and only one sample of the nine collected from site MW199A had orthophosphate accounting for more than 40 percent of filtered phosphorus. The anomalous sample collected on May 9, 2006, had $420 \mu \mathrm{g} / \mathrm{L}$ of filtered phosphorus with 90 percent as orthophosphate. The mean phosphorus concentration for site MW200 was $39 \mu \mathrm{g} / \mathrm{L}$, but seven of nine samples were less than $30 \mu \mathrm{g} / \mathrm{L}$. The largest concentrations of filtered phosphorus $(260 \mu \mathrm{g} / \mathrm{L})$ and filtered orthophosphate $(240 \mu \mathrm{g} / \mathrm{L})$ in the outflow from detention basin PA1 was in a sample collected on May 10, 2006. The second largest concentration of filtered phosphorus ( $84 \mu \mathrm{g} / \mathrm{L}$ ) and filtered orthophosphate $(68 \mu \mathrm{g} / \mathrm{L})$ was measured in samples from site MW200 and also was collected on May 10, 2006. MW199A has the largest measurement of hydraulic conductivity (20 ft/d; table 2). Attempts to slug test at site MW200 were unsuccessful because the stressed water level recovered too quickly for quantification. The rapid recovery indicates that the hydraulic conductivity of the aquifer material tapped at site MW200 is greater than $20 \mathrm{ft} / \mathrm{d}$, and may represent localized deposits that permit preferential flow of stormwater to ground water. 
A.

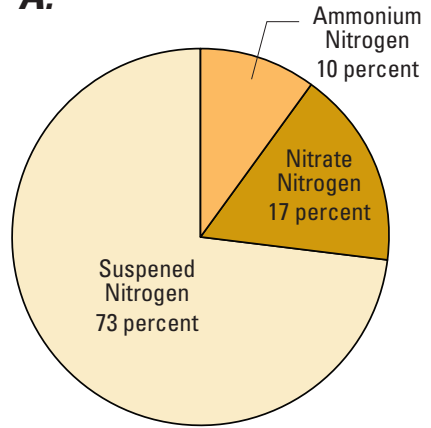

PA1_INLET A, NITROGEN SPECIATION UNFILTERED NITROGEN: 1,800 MICROGRAMS PER LITER

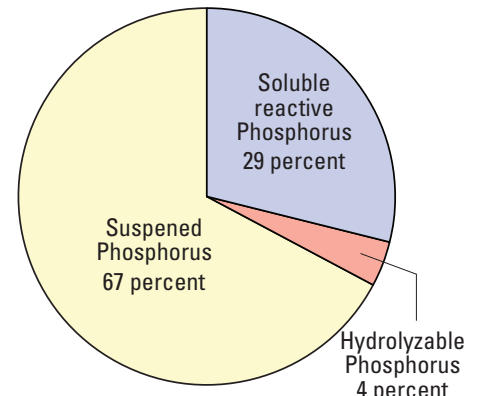

PA1_INLET A PHOSPHORUS SPECIATION UNFILTERED PHOSPHORUS: 460 MICROGRAMS PER LITER
D.

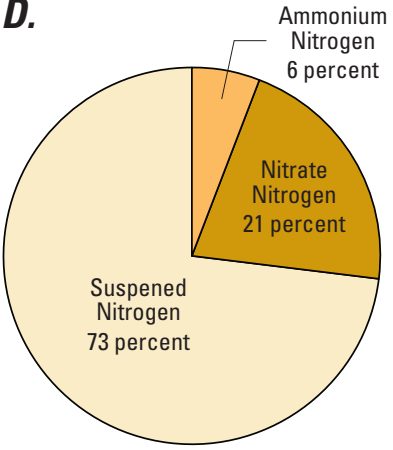

PA1_OUTFLOW, NITROGEN SPECIATION UNFILTERED NITROGEN: 720 MICROGRAMS PER LITER

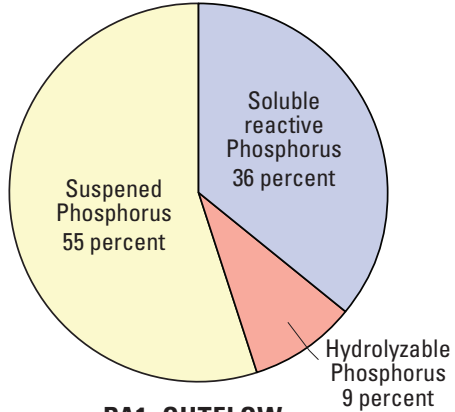

PA1_0UTFLOW PHOSPHORUS SPECIATION UNFILTERED PHOSPHORUS: 200 MICROGRAMS PER LITER

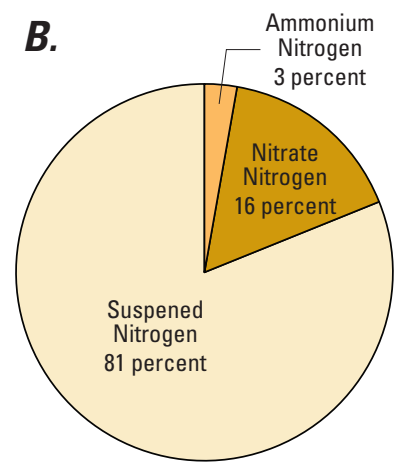

PA1_INLET B, NITROGEN SPECIATION UNFILTERED NITROGEN: 1,200 MICROGRAMS PER LITER

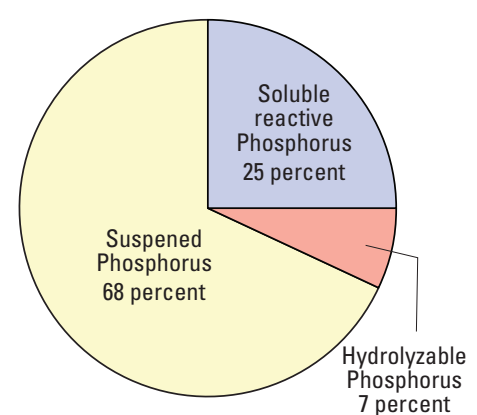

PA1 INLET B, PHOSPHORUS SPECIATION UNFILTERED PHOSPHORUS: 300 MICROGRAMS PER LITER

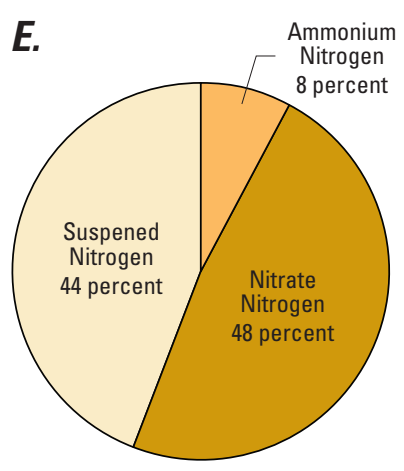

PA2_OUTFLOW, NITROGEN SPECIATION UNFILTERED NITROGEN: 320 MICROGRAMS PER LITER

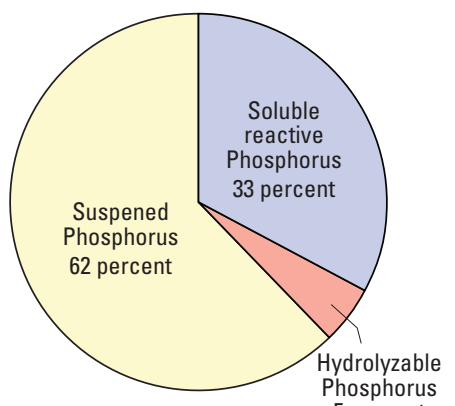

PA2_OUTFLOW, PHOSPHORUS SPECIATION UNFILTERED PHOSPHORUS: 1,800 MICROGRAMS PER LITER

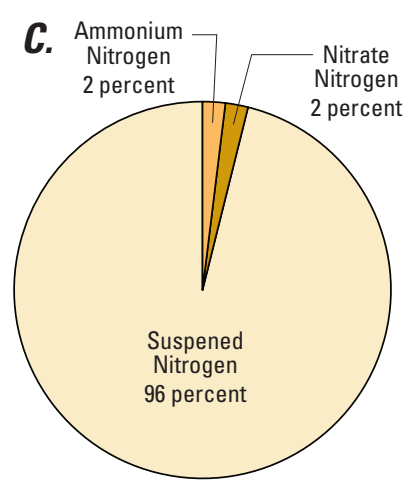

PA1,

NITROGEN SPECIATION UNFILTERED NITROGEN: 1,700 MICROGRAMS PER LITER

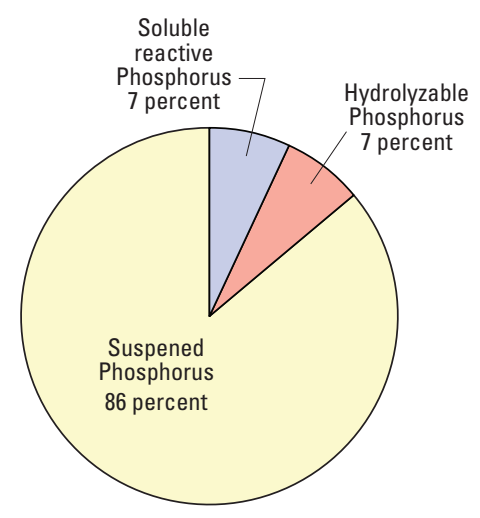

PA1,

PHOSPHORUS SPECIATION UNFILTERED PHOSPHORUS: 650 MICROGRAMS PER LITER

Figure 16. Relative contribution of nutrient species that constitute mean concentrations of nitrogen and phosphorus, South Lake Tahoe, California and Nevada. 
F.

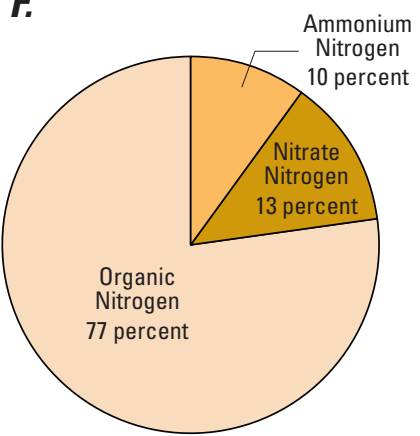

MW194,

NITROGEN SPECIATION

FILTERED NITROGEN:

440 MICROGRAMS PER LITER

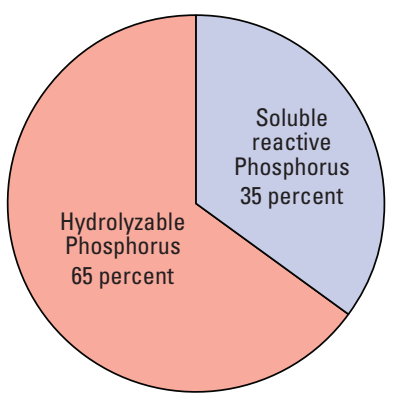

MW194,

PHOSPHORUS SPECIATION FILTERED PHOSPHORUS: 20 MICROGRAMS PER LITER
I.

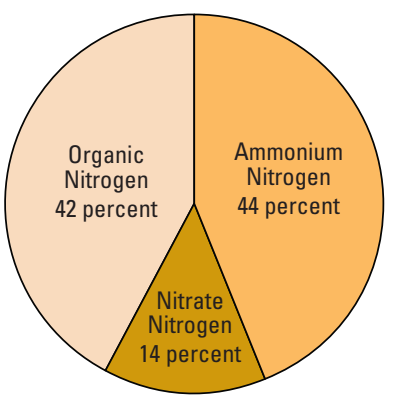

MW198A,

NITROGEN SPECIATION FILTERED NITROGEN: 610 MICROGRAMS PER LITER

J.

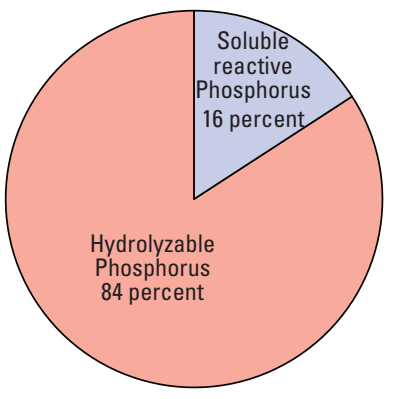

MW196,

PHOSPHORUS SPECIATION FILTERED PHOSPHORUS: 19 MICROGRAMS PER LITER
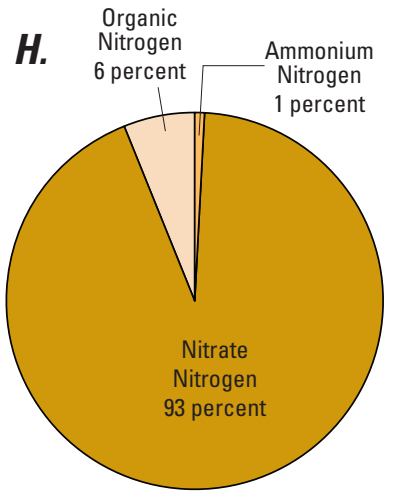

MW197,

NITROGEN SPECIATION FILTERED NITROGEN: 2,700 MICROGRAMS PER LITER

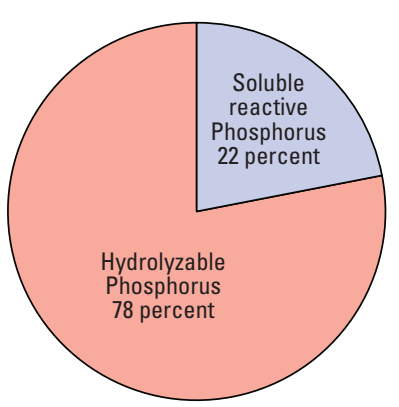

MW197,

PHOSPHORUS SPECIATION FILTERED PHOSPHORUS: 23 MICROGRAMS PER LITER
K.

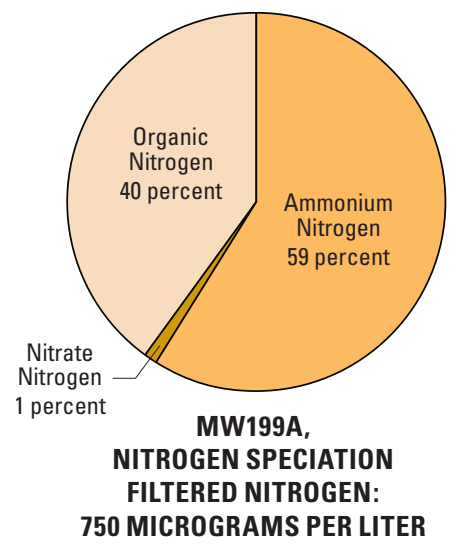

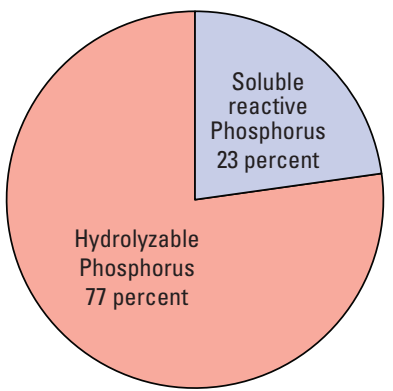

MW198A,

PHOSPHORUS SPECIATION FILTERED PHOSPHORUS: 22 MICROGRAMS PER LITER

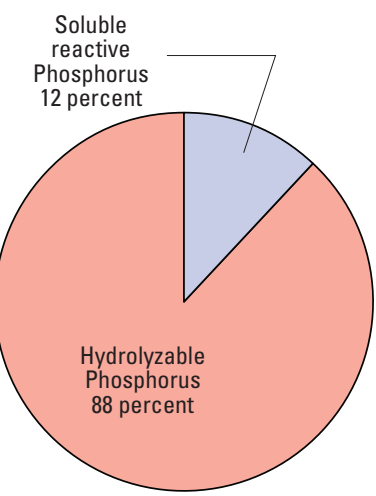

MW198B,

PHOSPHORUS SPECIATION FILTERED PHOSPHORUS: 17 MICROGRAMS PER LITER

Figure 16.-Continued. 
$L$.

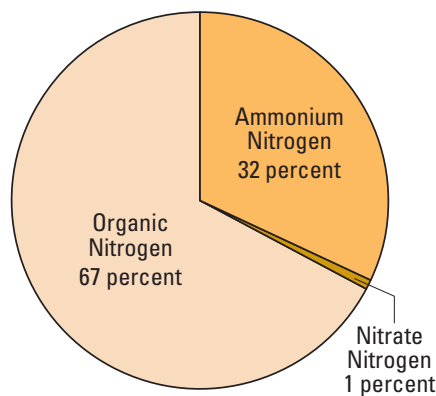

MW199B,

NITROGEN SPECIATION

FILTERED NITROGEN:

280 MICROGRAMS PER LITER

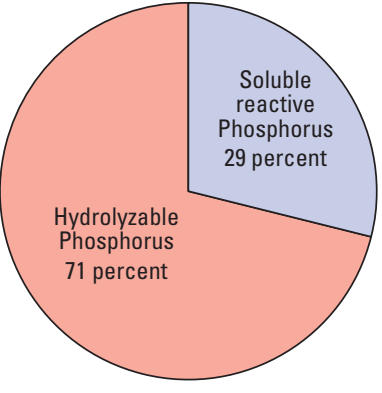

MW199B,

PHOSPHORUS SPECIATION

FILTERED PHOSPHORUS:

24 MICROGRAMS PER LITER
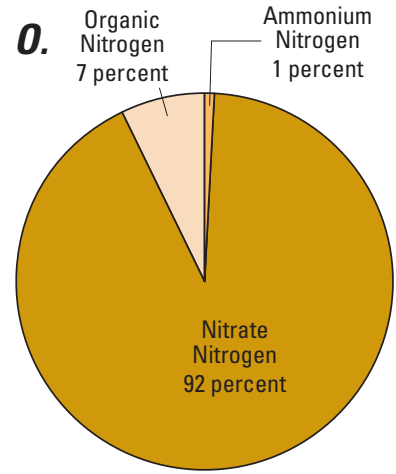

MW201B,

NITROGEN SPECIATION

FILTERED NITROGEN:

1,300 MICROGRAMS PER LITER

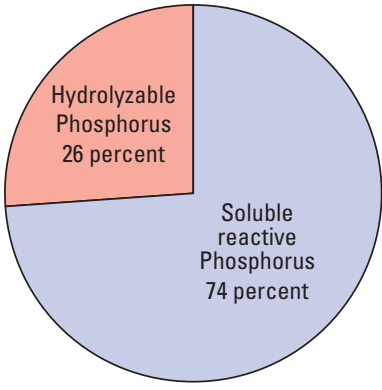

MW201B

PHOSPHORUS SPECIATION

FILTERED PHOSPHORUS: 46 MICROGRAMS PER LITER
M.

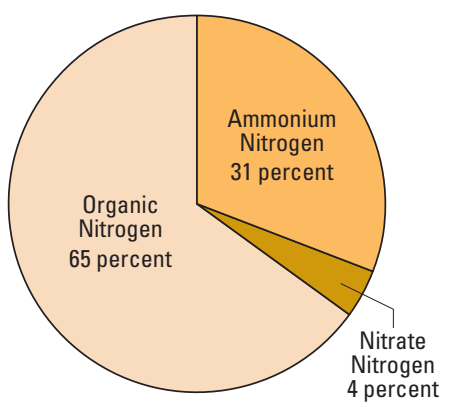

MW200,

NITROGEN SPECIATION

FILTERED NITROGEN: 390 MICROGRAMS PER LITER

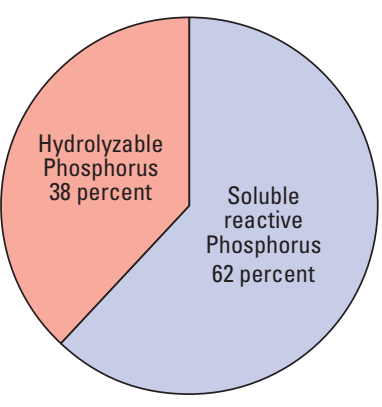

MW200,

PHOSPHORUS SPECIATION

FILTERED PHOSPHORUS: 39 MICROGRAMS PER LITER
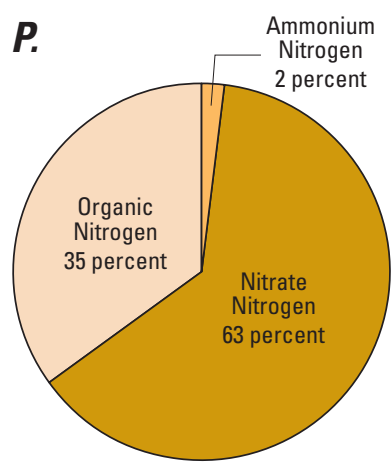

MW202

NITROGEN SPECIATION

FILTERED NITROGEN: 560 MICROGRAMS PER LITER

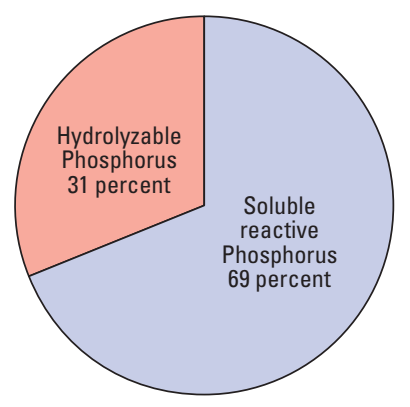

MW202,

PHOSPHORUS SPECIATION FILTERED PHOSPHORUS: 29 MICROGRAMS PER LITER
$\boldsymbol{N}$.

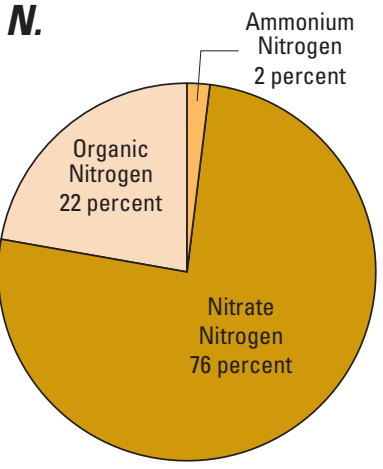

MW201A,

NITROGEN SPECIATION

FILTERED NITROGEN:

890 MICROGRAMS PER LITER
Hydrolyzable

Phosphorus

11 percent

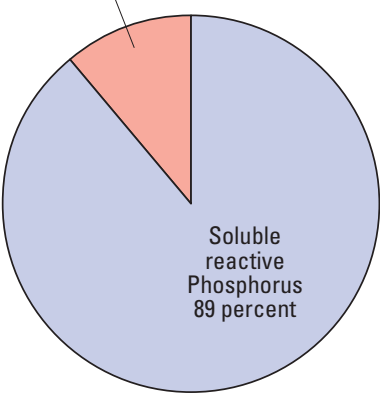

MW201A,

PHOSPHORUS SPECIATION

FILTERED PHOSPHORUS:

120 MICROGRAMS PER LITER
0.

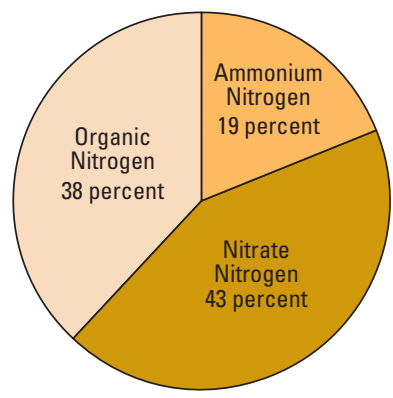

MEAN GROUND WATER, NITROGEN SPECIATION FILTERED NITROGEN: 560 MICROGRAMS PER LITER

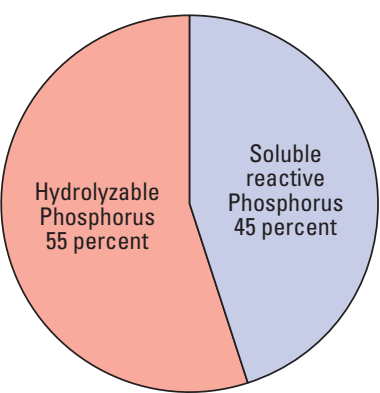

MEAN GROUND WATER, PHOSPHORUS SPECIATION FILTERED PHOSPHORUS: 29 MICROGRAMS PER LITER

Figure 16.-Continued. 
Concentrations of filtered nitrogen $(560-1,300 \mu \mathrm{g} / \mathrm{L})$ in samples from sites downgradient of detention basin PA2 (sites MW201A, MW201B, and MW202) are dominated by nitrate (63-92 percent) because detention basin PA2 only received stormwater inflow during flooding due to a warm rain-on-snow events that spanned December 17, 2005, through January 7, 2006. Therefore, nitrate in the shallow regional ground water is only diluted and displaced intermittently. Sites MW201A and MW202 are completed at $13 \mathrm{ft}$ below land surface and site MW201B was completed at $23 \mathrm{ft}$. Samples from the deeper well had a mean filtered nitrogen concentration of $1,300 \mu \mathrm{g} / \mathrm{L}$ compared to $890 \mu \mathrm{g} / \mathrm{L}$ for site MW201A and $560 \mu \mathrm{g} / \mathrm{L}$ for site MW202. Mean concentrations of filtered phosphorus (29-120 $\mu \mathrm{g} / \mathrm{L})$ for these three wells are all at least 69 percent orthophosphate and are among the five largest mean concentrations.

\section{Ground-Water Discharge and Nutrient Loading to Lake Tahoe}

In order to estimate the load of nutrients discharged to Lake Tahoe directly from detention basin PA1, an estimate of the amount of stormwater infiltrated from the detention basin was needed. Detention basin PA1 was not instrumented to record basin outflow; therefore, a calibrated-infiltration rate from the ground-water flow model of $73 \mathrm{ft}^{3} / \mathrm{d}$ was used. Thus, an estimated $18 \mathrm{ft}^{3} / \mathrm{d}$ of stormwater that infiltrated through the bed of detention basin PA1 discharges to Lake Tahoe based on particle tracking results of 25 percent direct discharge. The remaining $55 \mathrm{ft}^{3} / \mathrm{d}(0.46$ acre- $\mathrm{ft} / \mathrm{yr})$ of infiltrated stormwater discharged to stormdrains that discharge into Lake Tahoe by way of a wet meadow or was evapotranspired by riparian vegetation. The volume of infiltrated stormwater that discharges to Lake Tahoe as ground water represents about 0.1 percent ( $0.15 \mathrm{acre}-\mathrm{ft} / \mathrm{yr})$ of the total volume of groundwater discharge from the study area (256 acre-ft/yr). Assuming a mean filtered nitrogen concentration in ground water of 1,100 $\mu \mathrm{g} / \mathrm{L}$ and filtered phosphorus concentration of 39 $\mu \mathrm{g} / \mathrm{L}$, it is estimated that ground water within the study area contributes $765 \mathrm{lb}$ of nitrogen and $27 \mathrm{lb}$ of phosphorus each year to Lake Tahoe and infiltrated stormwater from detention basin PA1 contributes less than $0.45 \mathrm{lb}$ of the nitrogen load and less than $0.1 \mathrm{lb}$ of the phosphorus load to the lake.

The distribution of ground-water discharge across the lake sediment is important because heterogeneity of aquifer permeability can "focus" ground-water discharge, such as ground-water discharge to springs. The calibrated groundwater flow model was used to calculate zones of discharge to the lake (fig. 9$)$. About 41 acre-ft/yr (16 percent) of total ground-water discharge to Lake Tahoe occurs within about $60 \mathrm{ft}$ of the shoreline. Approximately 55 acre-ft/yr also discharges in a zone between $60 \mathrm{ft}$ and $600 \mathrm{ft}$ offshore.
Particle tracking was used to observe where infiltrated stormwater into the Park Avenue detention basins would discharge. Nearly 9,000 particles were placed in model cells representing detention basin PA1. The number of particles placed in each model cell was proportional to the groundwater flux through that particular cell. Results indicate that 75 percent of infiltrated stormwater discharges to nearby stormdrains northwest of detention basin PA1 while the remaining 25 percent discharges to Lake Tahoe within $60 \mathrm{ft}$ of the shoreline. Ground water discharged to stormdrains is conveyed to nearby wet meadows and directly to Lake Tahoe depending on diversion-dam configuration.

Other methods were attempted to determine locations of ground-water discharge to Lake Tahoe. Differences in the temperature and electrical conductivity of ground water compared to the receiving lake water have been used to locate submerged ground-water discharge for subsequent measurement of limnologic responses (Lee, 1985). Paired thermocouples attached to a data logger were dragged behind a boat along the Lake Tahoe shoreline, but wave action and airtemperature variations affected the data logger performance, preventing useful results.

An attempt was made to apply Raman Spectra fiber optic distributed temperature sensing technology in collaboration with researchers from the University of Nevada, Reno; Oregon State University; and others in June 2007. The system precisely measures temperature $\left( \pm 0.05^{\circ} \mathrm{C}\right)$ along a $3,000 \mathrm{ft}$ length of standard optical communication cable with 3 -ft spatial resolution (Hausner and others, 2007). Unfortunately, the equipment was available only during early June 2007 when a cold front moved in with wind and snow that again obscured any differences in lakebed temperatures.

On July 26 and August 2, 2007, a multiparameter water-quality probe was again dragged along the nearshore lakebed. However, no variations in temperature or electrical conductivity were observed. Thick mats of attached algae were observed in a linear pattern parallel to the lakeshore that indicated focused ground-water discharge. A seepage meter and minipiezometer were inserted into the lakebed sediment, and lake level and intercepted ground-water levels were compared using transparent tubing. Two samples of interstitial water and eight samples of lake water were collected for laboratory determination of stable isotopes of hydrogen and oxygen and for filtered concentrations of nitrogen and phosphorus.

Three lake samples were collected $1 \mathrm{ft}$ beneath the lake surface and five were collected at the lakebed-water contact. Relations between the two isotopic ratios (fig. 14) indicate that the lake water was well mixed with a slight groundwater signature in the samples collected at site L4B, near the lakebed (table A7). One interstitial water sample was nearly all ground water (site L3C) and the other (site L1C) falls along a linear mixing line between ground water and lake water. Filtered concentrations of nitrogen and phosphorus were less than laboratory reporting limits for all lake water 
samples except for one sample collected near the lakebed (site L3B) that had $71 \mu \mathrm{g} / \mathrm{L}$ of nitrogen. The sample of interstitial water indicated a mixture of lake and ground water (site L1C). This sample had $143 \mu \mathrm{g} / \mathrm{L}$ of nitrogen and 36 $\mu \mathrm{g} / \mathrm{L}$ phosphorus comprised mostly of organic nitrogen and orthophosphate, respectively. The other sample (site L3C) had $720 \mu \mathrm{g} / \mathrm{L}$ of filtered nitrogen comprised of 65 percent ammonium, 35 percent organic nitrogen and detectable nitrite ( $3 \mu \mathrm{g} / \mathrm{L}$ ), and $40 \mu \mathrm{g} / \mathrm{L}$ filtered phosphorus comprised of 72 percent orthophosphate and 28 percent hydrolyzable phosphorus. Filtered nitrogen concentrations in ground-water samples collected from wells averaged $1,000 \mu \mathrm{g} / \mathrm{L}$ with nitrate representing nearly 70 percent of the concentration and ammonium only 10 percent. Nitrate was less than reporting levels in the interstitial water (estimated as $10 \mu \mathrm{g} / \mathrm{L}$ from site L1C) indicating a dissimilative nitrate reduction to ammonium by sediment micro-organisms (Sørensen, 1978).

\section{Summary and Conclusions}

Clarity of Lake Tahoe, California and Nevada, has been decreasing, in part due to inflows of sediment and nutrients associated with stormwater runoff. Constructed stormwater detention basins are considered effective best management practices for mitigation of suspended sediment and nutrients associated with runoff, but consequences of infiltrated stormwater to shallow ground water are not known. This report documents 2005-07 hydrogeologic conditions in a small part of a shallow aquifer and how it interacts with a stormwater-control system and with nearby Lake Tahoe. Descriptions of the basin-fill aquifer and a stormwater-control system; quantification of components of the ground-water budget; and characteristics of the quality of stormwater, bottom sediment from a stormwater detention basin, ground water, and nearshore lake and interstitial water are included. Results of a three-dimensional, finite-difference, numerical model also are presented, coupled with chemical data to evaluate responses of ground-water flow to stormwater runoff accumulation in the stormwater-control system.

Ground-water flow in the basin-fill aquifer was modeled using five layers of constant thickness $(5,10,15,10$ and $10 \mathrm{ft}$ thick, respectively), from land surface to $50 \mathrm{ft}$ and a sixth layer that varied in thickness from the bottom of layer 5 to bedrock. The large and varying thickness of this deepest layer is assumed to have no effect on the simulation of shallow ground-water movement. Information indicates lacustrine layers may be interspersed within sand and gravel deposits, but enough evidence was not available to support a continuous confining layer in this model. Bedrock underlying layer 6 represents a basal no-flow boundary and boundaries to the northeast and southwest were aligned along hydrographic basin boundaries and were represented as no-flow boundaries. Model cells exposed to Lake Tahoe in the northwest were simulated using a constant-head boundary of $6,225 \mathrm{ft}$, which is the average stage of Lake Tahoe. The southern Park Avenue detention basin also was simulated using a constant-head boundary because it was never observed to completely drain.

Model layers 1-5 were assigned hydraulic conductivity values of $2 \mathrm{ft} / \mathrm{d}$ for the simulations. Recharge was applied to the modeled area as precipitation (areal recharge) and mountain-front recharge. Areal recharge was estimated during model calibration and applied to about 62 percent of layer 1 model cells that were determined not to be impervious. Mountain-front recharge was applied to all cells along the southeast boundary, as well as two zones that extend downgradient from the mountain front. Annual precipitation averaged 4,400 acre-ft in the watersheds upgradient of the model area between 1971 and 2000, of which 2 percent was estimated to be in-place recharge, 54 percent is consumed by evapotranspiration, and the remaining 44 percent is attributed to potential runoff. The percentage of the potential runoff that actually becomes recharge was estimated during model calibration.

A network of stormwater drainage ditches and sewers scattered across South Lake Tahoe were simulated as drains. These drains were placed $5 \mathrm{ft}$ below land surface. In this way, if the simulated ground-water surface came within $5 \mathrm{ft}$ of land surface, ground water would be able to discharge to the stormwater ditches, and then directly to Lake Tahoe.

The steady-state model was calibrated to water-level measurements in 18 wells and a mean ground-water discharge from the model domain was estimated to be 256 acre-ft/yr to Lake Tahoe. About 0.61 acre-ft/yr infiltrates from detention basin PA1 to ground water and particle tracking indicated 25 percent ( 0.15 acre-ft/yr) of this infiltration ultimately discharges to Lake Tahoe within $60 \mathrm{ft}$ of the shoreline. The remaining 0.46 acre-ft/yr discharged to local stormdrains that convey water to nearby wet meadows and directly to Lake Tahoe, depending on diversion-dam configuration.

Settling of suspended nutrients and sediment, biological assimilation of dissolved nutrients, and accumulation of chemicals of potential concern are the primary stormwater treatments achieved by the detention basins. Comparison of mean concentrations of unfiltered nitrogen and phosphorus in stormwater samples indicate that 55 percent of nitrogen and 47 percent of phosphorus is trapped in the detention basin. Cadmium, copper, lead, mercury, nickel, organic carbon, phosphorus, and zinc in the uppermost $0.2 \mathrm{ft}$ of bottom sediment from the detention basin were all at least twice as concentrated compared to sediment collected from $1.5 \mathrm{ft}$ deeper. Similarly, concentrations of 28 polycyclic aromatic hydrocarbon compounds were all less than laboratory reporting limits in the deeper sample, but 15 compounds were measured in the uppermost $0.2 \mathrm{ft}$ of bottom sediment. Published concentrations determined to affect benthic aquatic life were exceeded for benz[a]anthracene, copper, phenanthrene, pyrene, and zinc in the uppermost $0.2 \mathrm{ft}$ of bottom sediment. 
Concentrations of filtered major ions indicate that upgradient ground water is a mixed cation-bicarbonate type with $152 \mathrm{mg} / \mathrm{L}$ total solutes that evolves to a mixed cation/ mixed anion, sodium-chloride type and sodium-bicarbonate type waters with up to $390 \mathrm{mg} / \mathrm{L}$ total solutes, possibly due to residual leachate from abandoned septic-tank systems and recharged stormwater runoff. Concentrations of filtered nitrogen ranged from 82 to $4,600 \mu \mathrm{g} / \mathrm{L}$ and phosphorus ranged from 4 to $420 \mu \mathrm{g} / \mathrm{L}$. Coupling mean concentrations of phosphorus (39 $\mu \mathrm{g} / \mathrm{L})$ and nitrogen $(1,100 \mu \mathrm{g} / \mathrm{L})$ with the steady-state ground-water flow model yields annual estimates of $26 \mathrm{lb}$ of phosphorus and $770 \mathrm{lb}$ of nitrogen that may be transported with ground water to Lake Tahoe from the modeled area (1.5 percent of the total area that is tributary to the lake).

The isotopic composition of water, expressed as ratios of oxygen-18 relative to oxygen-16 (delta oxygen-18) and deuterium relative to hydrogen-1 (delta deuterium), of local ground water is different from that of Lake Tahoe due to evaporative fractionation of lake water that has an estimated residence time of 700 years. Comparison of delta oxygen-18 and delta deuterium ratios for samples of shallow ground water, lake water, and interstitial water from Lake Tahoe indicates the lake water was well mixed with a slight groundwater signature in two of five lake-water samples collected near the lakebed. One of two interstitial water samples from $0.8 \mathrm{ft}$ beneath the lakebed was nearly all ground water and concentrations of nitrogen and phosphorus were comparable to concentrations in shallow ground-water samples. The other interstitial sample fell along a mixing line between ground water and lake water, and nutrient concentrations appeared diluted with lake water. Nitrate was less than laboratory reporting levels in both interstitial samples, indicating a dissimilative nitrate reduction to ammonium by micro-organisms. Based on average nitrogen and phosphorus concentrations of interstitial-water samples and ground-water discharge to Lake Tahoe directly from detention basin PA1, it is estimated that PA1 contributes loads of less than $0.3 \mathrm{lb}$ of nitrogen and less than $0.1 \mathrm{lb}$ of phosphorus per year.

\section{Acknowledgments}

Acknowledgments are expressed to Nicole G. Beck, Ph.D., 2NDNATURE, LLC, for collaboration and the data provided for this investigation. Special thanks are extended to Jack Pugh, the Tahoe Meadows Homeowners Association, and individual homeowners who provided access to private properties and domestic wells. Russell Wigart and Jennifer Quickel, City of South Lake Tahoe, California and Ginger Huber, El Dorado County Health Department, City of South Lake Tahoe, California provided logistical support for well construction and permit acquisition and to Ivo Bergsohn, South Lake Tahoe Public Utility District, City of South Lake Tahoe, California for information on aquifer properties and access to monitoring wells.

\section{References Cited}

American Public Health Association, 1998, Standard methods for the examination of water and wastewater (20 $0^{\text {th }}$ ed.): Washington, D.C., American Public Health Association, American Water Works Association, and Water Environment Federation, p. 3-37-3-43.

Arbogast, B.F., ed., 1996, Analytical methods manual for the mineral resource surveys program, U.S. Geological Survey: U.S. Geological Survey Open-File Report 96-525, 248 p.

Armin, R.A., and John, D.A., 1983, Geologic map of the Freel Peak 15-minute quadrangle, California and Nevada, with Quaternary geology by J.C. Dohrenwend: U.S. Geological Survey Miscellaneous Investigations Series Map I-1424, scale $1: 62,500$.

Bergsohn, Ivo, 2000, Blackrock well no. 2, vulnerability study, pumping test report: South Tahoe Public Utility District, $30 \mathrm{p}$.

Bonham, H.F., Jr., and Burnett, J.L., 1976, Geologic map of the South Lake Tahoe 7.5-minute quadrangle: Nevada Bureau of Mines and Geology Map 2Ag, scale 1:24,000.

Bouwer, Herman, and Rice, R.C., 1976, A slug test for determining hydraulic conductivity of unconfined aquifers with completely or partially penetrating wells: Water Resources Research, v. 12, no. 3, p. 423-428.

Brenton, R.W., and Arnett, T.L., 1993, Methods of analysis by the U.S. Geological Survey National Water Quality Laboratory-Determination of dissolved organic carbon by UV-promoted persulfate oxidation and infrared spectrometry: U.S. Geological Survey Open-File Report 92-480, 12 p.

Briggs, P.H., and Meier, A.L., 1999, The determination of forty two elements in geological materials by inductively coupled plasma - mass spectrometry: U.S. Geological Survey Open-File Report 99-166, 15 p.

Brock, T.D., Lee, D.R., Janes, David, and Winek, David, 1982, Groundwater seepage as nutrient source to a drainage lake, Lake Mendota, Wisconsin: Water Research, v. 16, issue 7, p. 1255-1263.

California Regional Water Quality Control Board, Lahontan Region, 2005, Updated waste discharge requirements and National Pollutant Discharge Elimination System (NPDES) permit for storm water/urban runoff from El Dorado County, Placer County, and the city of South Lake Tahoe: order no. R6T-2005-0026, NPDES no. CAG616001.

City of South Lake Tahoe, 2008, Public/quasi-public facilities and services in general plan: City of South Lake Tahoe Background Report, Public Review Draft, June 2008, chap. 6, 71 p., available at http://sltgpu.com/ 
Cartier, K.D., Peltz, L.A., and Long, Kati, 1995, Hydrologic basins and hydrologic-monitoring sites of Lake Tahoe Basin, California and Nevada: U.S. Geological Survey Open-File Report 95-316, 1 sheet.

Coplen, T.B., 1994, Reporting of stable hydrogen, carbon, and oxygen isotopic abundances: Pure and Applied Chemistry, v. 66, p. 273-276.

Coplen, T.B., Wildman, J.D., and Chen, J., 1991, Improvements in the gaseous hydrogen-water equilibration technique for hydrogen isotope ratio analysis: Analytical Chemistry, v. 63, p. 910-912.

Craig, Harmon, 1961, Isotopic variations in meteoric waters: Science, v. 133, no. 3465, p. 1702-1703.

Crippen, J.R., and Pavelka, B.R., 1970, The Lake Tahoe basin, California-Nevada: U.S. Geological Survey Water-Supply Paper 1972, 56 p.

Epstein, S., and Mayeda, T., 1953, Variation of O-18 content of water from natural sources: Geochimica Cosmochimica Acta, v. 4, p. 213-224.

Fishman, M.J., ed., 1993, Methods of analysis by the U.S. Geological Survey National Water Quality LaboratoryDetermination of inorganic and organic constituents in water and fluvial sediments: U.S. Geological Survey OpenFile Report 93-125, 217 p.

Fishman, M.J., and Friedman, L.C., eds., 1989, Methods for determination of inorganic substances in water and fluvial sediments: U.S. Geological Survey Techniques of WaterResources Investigations, book 5, chap. A1, 545 p.

Flint, L.E., and Flint, A.L., 2007, Regional analysis of groundwater recharge, in Stonestrom, D.A., Constantz, Jim, Ferre, T.P.A., and Leake, S.A., eds., Ground-water recharge in the arid and semiarid southwestern United States: U.S. Geological Survey Professional Paper 1703-B, p. 29-60, available at http://pubs.usgs.gov/pp/pp1703/b/

Goldman, C.R., 1988, Primary productivity, nutrients, and transparency during the early onset of eutrophication in ultra-oligotrophic Lake Tahoe, California-Nevada: Limnology and Oceanography, v. 33, no. 6, p. 1321-1333.

Goldman, C.R., 2000, Four decades of change in two subalpine lakes: International Association of Theoretical and Applied Limnology, Proceedings, v. 27, p. 7-26.

Green, J.M., ed., 2006, The effectiveness of Cattlemans detention basin, South Lake Tahoe, California: U.S. Geological Survey Scientific Investigations Report 2006-5259, 81 p., available at http://pubs.usgs.gov/ $\underline{\text { sir/2006/5259 }}$
Hageman, P.L., 2007, Determination of mercury in aqueous and geologic materials by continuous flow-cold vapor-atomic fluorescence spectrometry (CVAFS): U.S. Geological Survey Techniques and Methods, book 5, chap. D2, 6 p., available at http://pubs.usgs.gov/tm/2007/05D02

Harbaugh, A.W., and McDonald, M.G., 1996, User's documentation for MODFLOW-96, an update to the U.S. Geological Survey modular finite-difference ground-water flow model: U.S. Geological Survey Open-File Report 96-485, $56 \mathrm{p}$.

Hausner, Mark, Tyler, S.W., Selker, John, Torgersen, Thomas, Schladow, G.S., Thodal, C.E., Menon, Menoj, Reddy, Sandhya, Bajwa, Tejbir, and Rawat, Banmali, 2007, Distributed temperature sensing-Design and protocols for hydrologic applications: Geological Society of America Abstracts with Programs, v. 39, no. 6, p. 112.

Heyvaert, A.C., Reuter, J.E., Slotton, D.G., and Goldman, C.R., 2000, Paleolimnological reconstruction of historical atmospheric lead and mercury deposition at Lake Tahoe, California-Nevada: Environmental Science and Technology, v. 34, issue 17, p. 3588-3597.

Hjortenkrans, D.S.T., Bergbäck, B.G., and Häggerud, A.V., 2007, Metal emissions from brake linings and tires: Case studies of Stockholm, Sweden 1995/1998 and 2005: Environmental Science and Technology, v. 41, issue 15, p. 5224-5230.

Ingersoll, C.G., MacDonald, D.D., Wang, Ning, Crane, J.L., Field, L.J., Haverland, P.S., Kemble, N.E., Lindskoog, R.A., Severn, Corrine, and Smorong, D.E., 2000, Prediction of sediment toxicity using consensus-based freshwater sediment quality guidelines: U.S. Geological Survey Final Report for the U.S. Environmental Protection Agency, Great Lakes National Program Office, EPA 905/R-00/007, 33 p.

Jorgensen, L.N., Seacer, A.L., and Kaus, S.J., 1978, Hydrologic basins contributing to outflow from Lake Tahoe, California-Nevada: U.S. Geological Survey Hydrologic Investigations Atlas HA-587, scale 1:62,500.

Lee, R.L., 1985, Method for locating sediment anomalies in lakebeds that can be caused by groundwater flow: Journal of Hydrology, v. 79, p. 187-193.

Liddicoat, M.I., Tibbits, S., and Butler, E.I., 1975, The determination of ammonia in seawater: Limnology and Oceanography, v. 20, p. 131-132.

Long, E.R., and Morgan, L.G., 1991, The potential for biological effects of sediment-sorbed contaminants tested in the National Status and Trends Program: Seattle, National Atmospheric and Oceanographic Administration Technical Memorandum NOS OMA 52, 175 p., plus appendixes. 
Martin, E.H., 1988, Effectiveness of an urban runoff detention basin-wetlands system: Journal of Environmental Engineering, v. 114, no. 4, p. 810-827.

McDonald, M.G., and Harbaugh, A.W., 1988, A modular three-dimensional finite-difference ground-water flow model: U.S. Geological Survey Techniques of WaterResources Investigations, book 6, chap. A1, 586 p.

Miller, W.W., Johnson, D.W., Denton, C., Verburg, P.S.J., Dana, G.L., and Walker, R.F., 2005, Inconspicuous nutrient laden surface runoff from mature Sierran watersheds: Water, Air, and Soil Pollution, v. 163, no. 1, p. 3-17.

Natural Resources Conservation Service, 2008, SNOTEL data and products: U.S. Department of Agriculture, Natural Resources Conservation Service and National Water Climate Center, accessed August 2008 at http://www.wcc. nrcs.usda.gov/snow/

Olson, M.C., Iverson, J.L., Furlong, E.T., and Schroeder, M.P., 2004, Methods of analysis by the U.S. Geological Survey National Water Quality Laboratory_-Determination of polycyclic aromatic hydrocarbon compounds in sediment by gas chromatography/mass spectrometry: U.S. Geological Survey Water-Resources Investigations Report 03-4318, 45 p., available at http://nwql.usgs.gov/Public/pubs/ WRIR03-4318/WRIR03-4318.html

Patton, C.J., and Kryskalla, J.R., 2003, Methods of analysis by the U.S. Geological Survey National Water Quality Laboratory_Evaluation of alkaline persulfate digestion as an alternative to Kjeldahl digestion for determination of total and dissolved nitrogen and phosphorus in water: U.S. Geological Survey Water-Resources Investigations Report 03-4174, 33 p., available at http://nwql.usgs.gov/Public/ pubs/WRIR03-4174/WRIR03-4174.html

Perkins, M.A., Goldman, C.R., and Leonard, R.L., 1975, Residual nutrient discharge in streamwaters influenced by sewage effluent spraying: Ecology, v. 56, issue 2, p. $453-460$.

Persaud, D., Jaagumagi, R., and Hayton, A., 1993, Guidelines for the protection and management of aquatic sediment quality in Ontario: Water Resources Branch, Ontario Ministry of the Environment and Energy, 24 p. plus appendixes.
Piper, A.M., Garrett, A.A., and others, 1953, Native and contaminated ground waters in the Long Beach-Santa Ana area, California: U.S. Geological Survey Water-Supply Paper 1136, $320 \mathrm{p}$.

Prudic, D.E., Sager, S.J., Wood, J.L., Henkelman, K.K., and Caskey, R.M., 2005, Chemistry of runoff and shallow ground water at the Cattlemans detention basin site, South Lake Tahoe, California, August 2000-November 2001: U.S. Geological Survey Scientific Investigations Report 2004-5254, 39 p., available at http://pubs.usgs.gov/ $\underline{\text { sir/2004/5254/ }}$

Raumann, C.G., 2007, Land-cover change in the southern Lake Tahoe Basin, California and Nevada, 1940-2002: U.S. Geological Survey Scientific Investigations Map 2962, scale 1:27,000, available at http://pubs.usgs.gov/ $\underline{\operatorname{sim} / 2007 / 2962 /}$

Reuter, J.E., Jassby, A.D., Marjanovic, P., Heyvaert, A.C., and Goldman C.R., 1998, Preliminary phosphorus and nitrogen budgets for Lake Tahoe, Annual Progress Report1998-Lake clarity and watershed modeling, Presidential deliverable: Tahoe Research Group, Department of Civil and Environmental Engineering, John Muir Institute for the Environment, University of California, Davis, 28 p.

Reuter, J.E., and Miller W.W., 2000, Chapter 4: Aquatic resources, water quality, and limnology of Lake Tahoe and its upland watershed; Lake Tahoe watershed assessment in Murphy, D.D., and Knopp, C.M., eds., The Lake Tahoe watershed assessment, volume I: U.S. Department of Agriculture, Forest Service General Technical Report, PSWGTR-175, p. 68-77.

Reuter, J.E., Marzolf, E.R., and Goldman, C.R., 1992, Water quality treatment of surface runoff in a natural subalpine meadow, Case study from the Lake Tahoe Basin, California: International Erosion Control Association, Proceedings of Conference XXIII, February 18-21, The Environment is Our Future, p. 17-35.

Rogers, J.H., 1974, Soil survey of the Tahoe Basin area, California and Nevada: U.S. Department of Agriculture Soil Conservation Service and Forest Service, map no. 9.

Rounds, S.A., 2006, Alkalinity and acid neutralizing capacity (ver. 3): U.S. Geological Survey Techniques of WaterResources Investigations, book 9, chap. A6.6, available at http://pubs.water.usgs.gov/twri9A 
Saucedo, G.J., compiler, 2005, Geologic map of the Lake Tahoe Basin, California and Nevada: California Geological Survey Regional Geologic Map Series, Map No. 4, 1:100,000 scale.

Schuster, S., and Grismer, M.E., 2004, Evaluation of water quality projects in the Lake Tahoe Basin: Environmental Monitoring and Assessment, v. 90, p. 225-242.

Schuster, P.F., Reddy, M.M., LaBaugh, J.W., Parkhurst, R.S., Rosenberry, D.O., Winter, T.C., Antweiler, R.C., and Dean, W.E., 2003, Characterization of lake water and ground water movement in the littoral zone of Williams Lake, a closed-basin lake in north central Minnesota: Hydrological Processes, v. 17, p. 823-838.

Smith, J.A., Witkowski, P.J., and Fusillo, T.V., 1988, Manmade organic compounds in the surface waters of the United States-A review of current understanding: U.S. Geological Survey Circular 1007, 92 p.

Smith, S.L., MacDonald, D.D., Keenleyside, K.A., Ingersoll, C.G., and Field, J., 1996, A preliminary evaluation of sediment quality assessment values for freshwater ecosystems: Journal of Great Lakes Research, v. 22, p. 624-638.

Solorzano, L., 1969, Determination of ammonia in natural waters by the phenolhypochlorite method: Limnology and Oceanography, v. 14, p. 799-801.

Sørensen, J., 1978, Capacity for denitrification and reduction of nitrate to ammonia in a coastal marine sediment: Applied and Environmental Microbiology, v. 35, p. 301-305.

Taggart, J.E., Jr., ed., 2002, Analytical methods for chemical analysis of geologic and other materials, U.S. Geological Survey: U.S. Geological Survey Open-File Report 02-223, 20 p., available at http://pubs.usgs.gov/of/2002/ofr-02-0223/
Taylor, K., 2002, Investigation of near shore turbidity at Lake Tahoe: Desert Research Institute, Division of Hydrologic Sciences Publication No. 41179, 22 p.

Thodal, C.E., 1997, Hydrogeology of Lake Tahoe Basin, California and Nevada, and results of a ground-water quality monitoring network, water years 1990-92: U.S. Geological Survey Water-Resources Investigations Report 97-4072, 53 p.

Thomas, James, Mihevc, Todd, Cooper, Clay, Gunter, Melissa, Heyvaert, Alan, and Michalski, Gregory, 2004, Groundwater nutrient loading to Lake Tahoe in a nearshore area with turbidity and chlorophyll: Desert Research Institute Publication No. 41213, 18 p.

U.S. Army Corps of Engineers, 2003, Lake Tahoe Basin framework study, groundwater evaluation Lake Tahoe Basin, California and Nevada: U.S. Army Corps of Engineers, Sacramento District, various pagination.

U.S. Geological Survey, variously dated, National field manual for the collection of water-quality data: U.S. Geological Survey Techniques of Water-Resources Investigations, book 9, chaps. A1-A9, available at: http://pubs.water.usgs.gov/twri9A

Winter, T.C., Harvey, J.W., Franke, O.L., and Alley, W.M., 1998, Ground water and surface water-A single resource: U.S. Geological Survey Circular 1139, 79 p., available at http://pubs.usgs.gov/circ/circ1139/

Woodworth, M.T., and Conner, B.F., 2003, Results of the U.S. Geological Survey's analytical evaluation program for standard reference samples distributed in March 2003: U.S. Geological Survey Open-File Report 03-261, 109 p. 
This page intentionally left blank. 
Appendix A. Water-Quality Data 


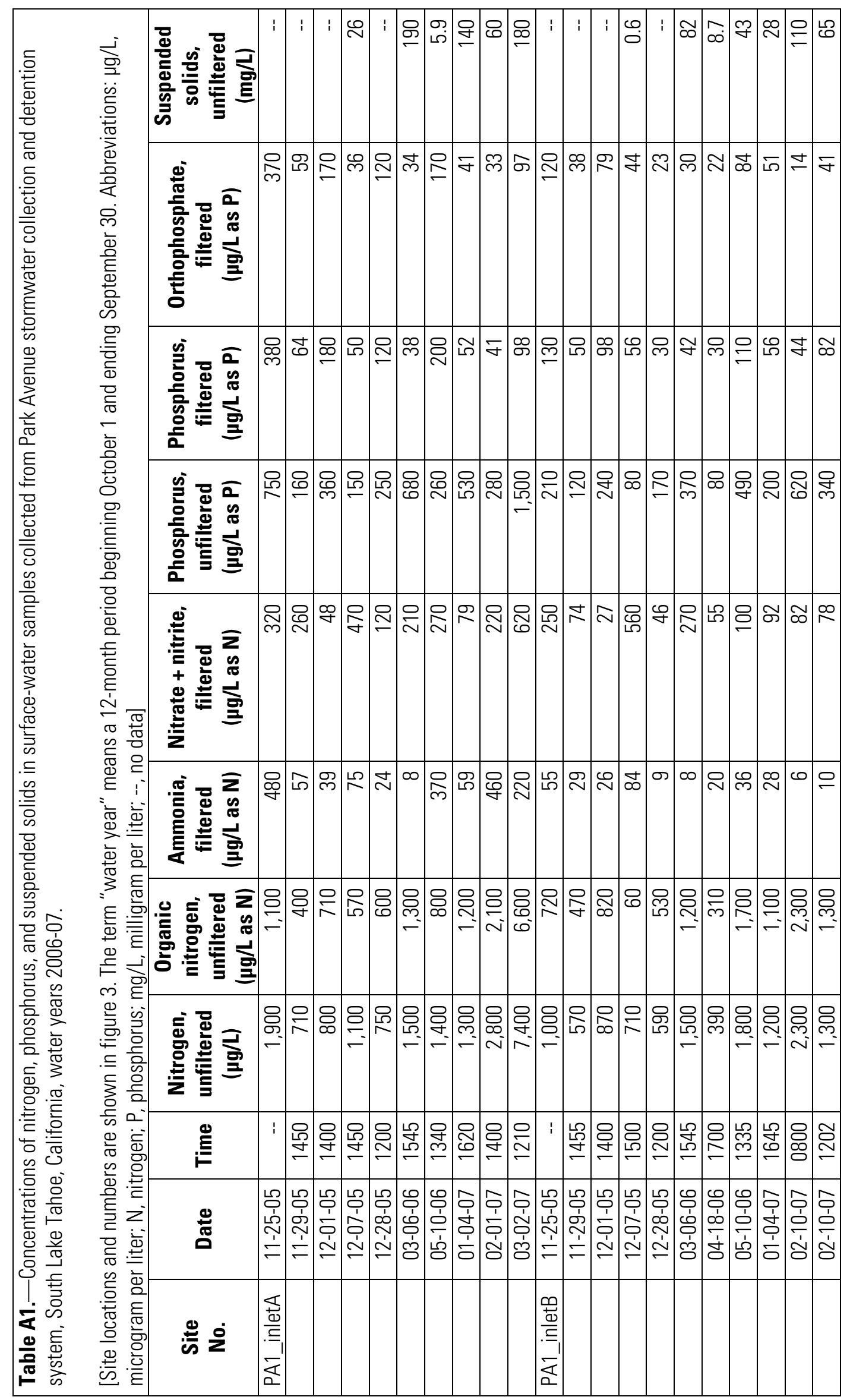




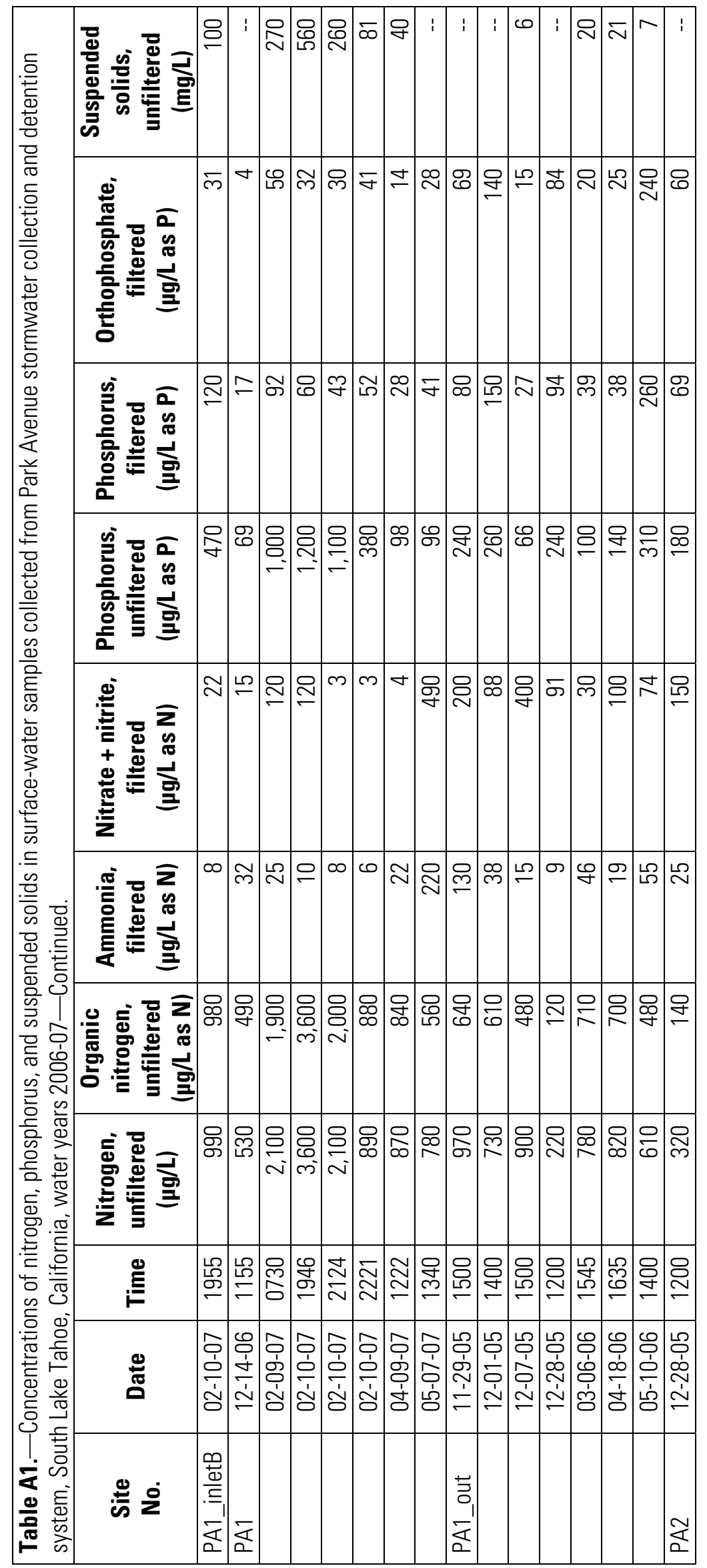




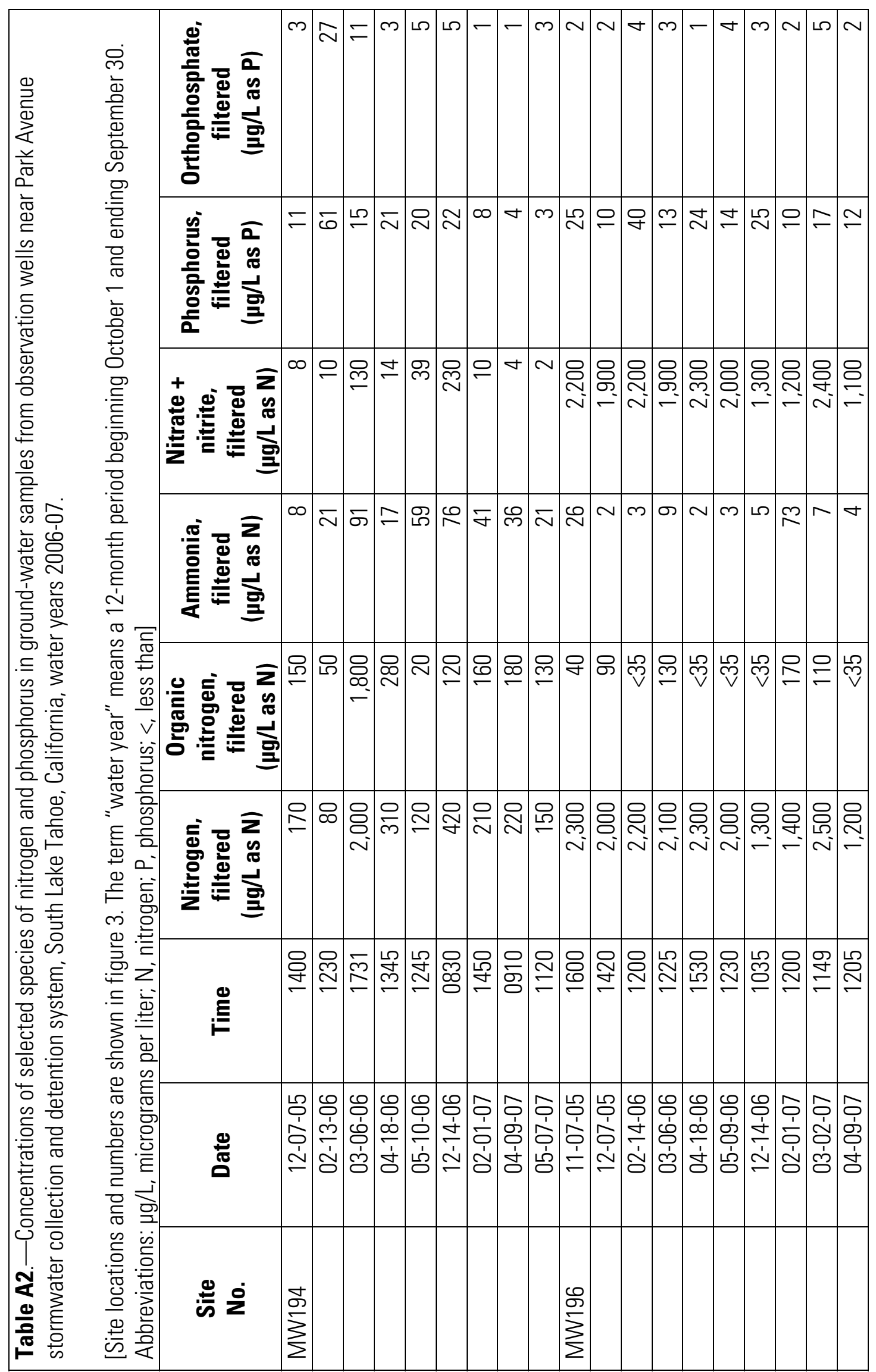




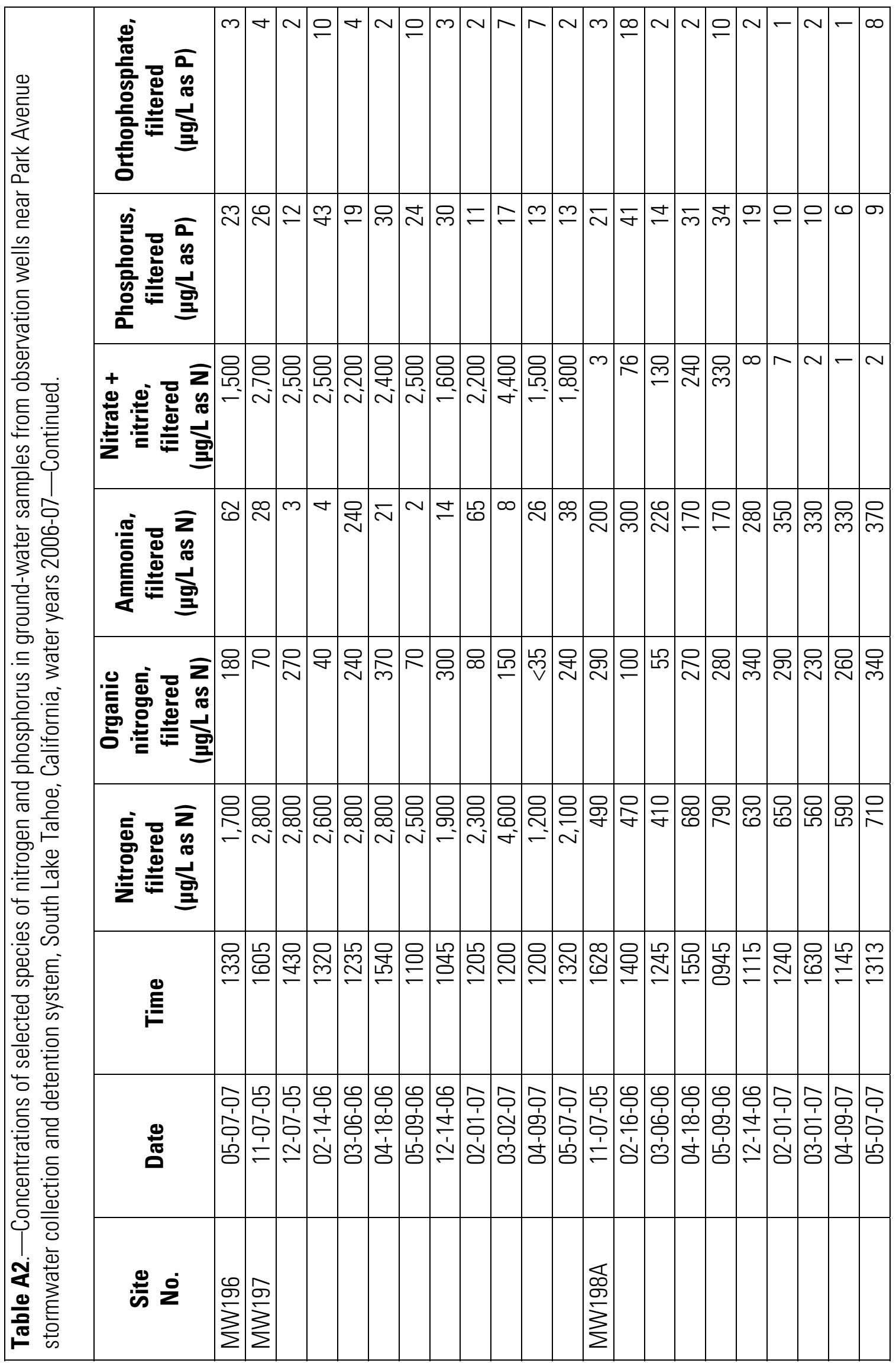




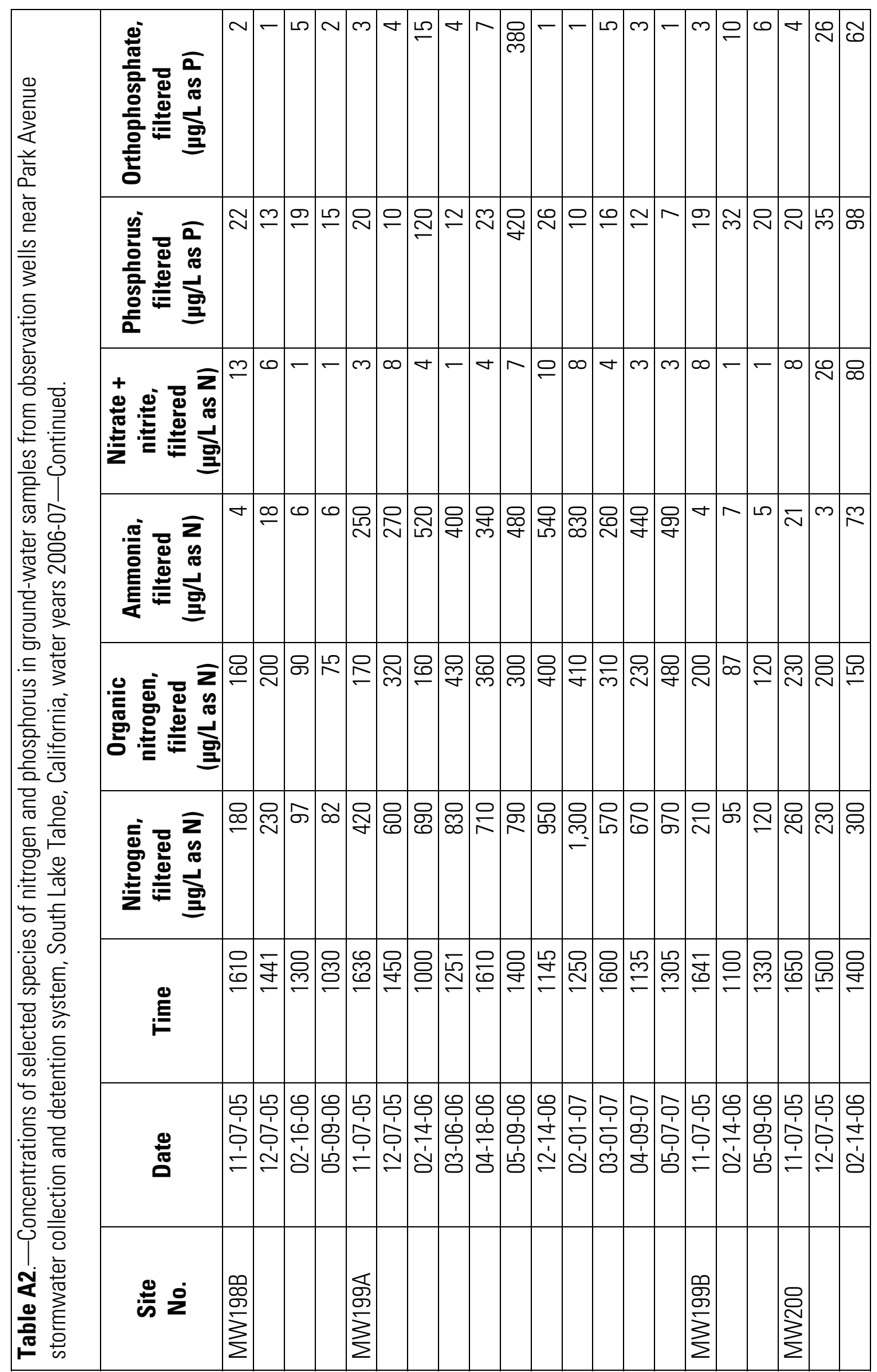




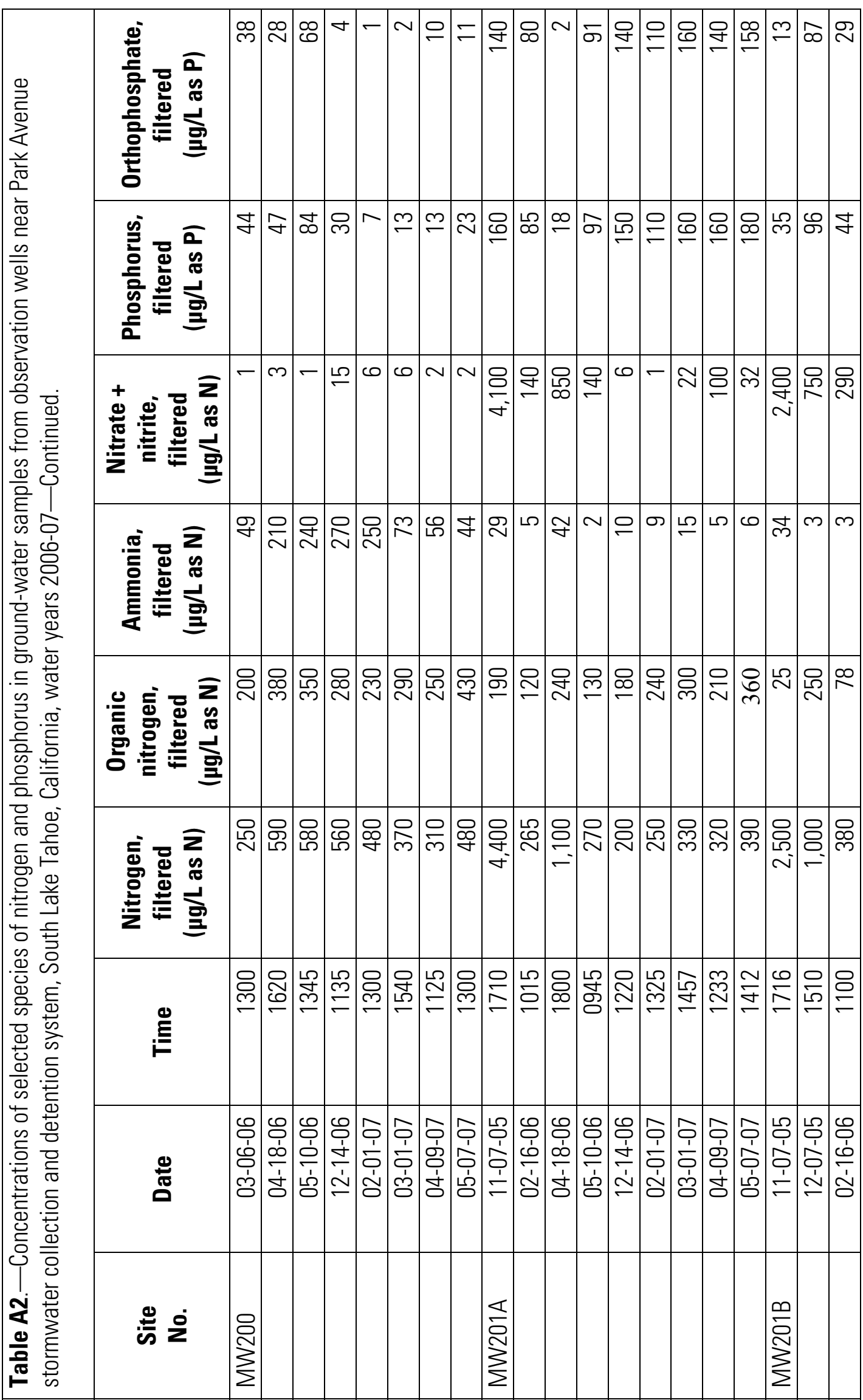




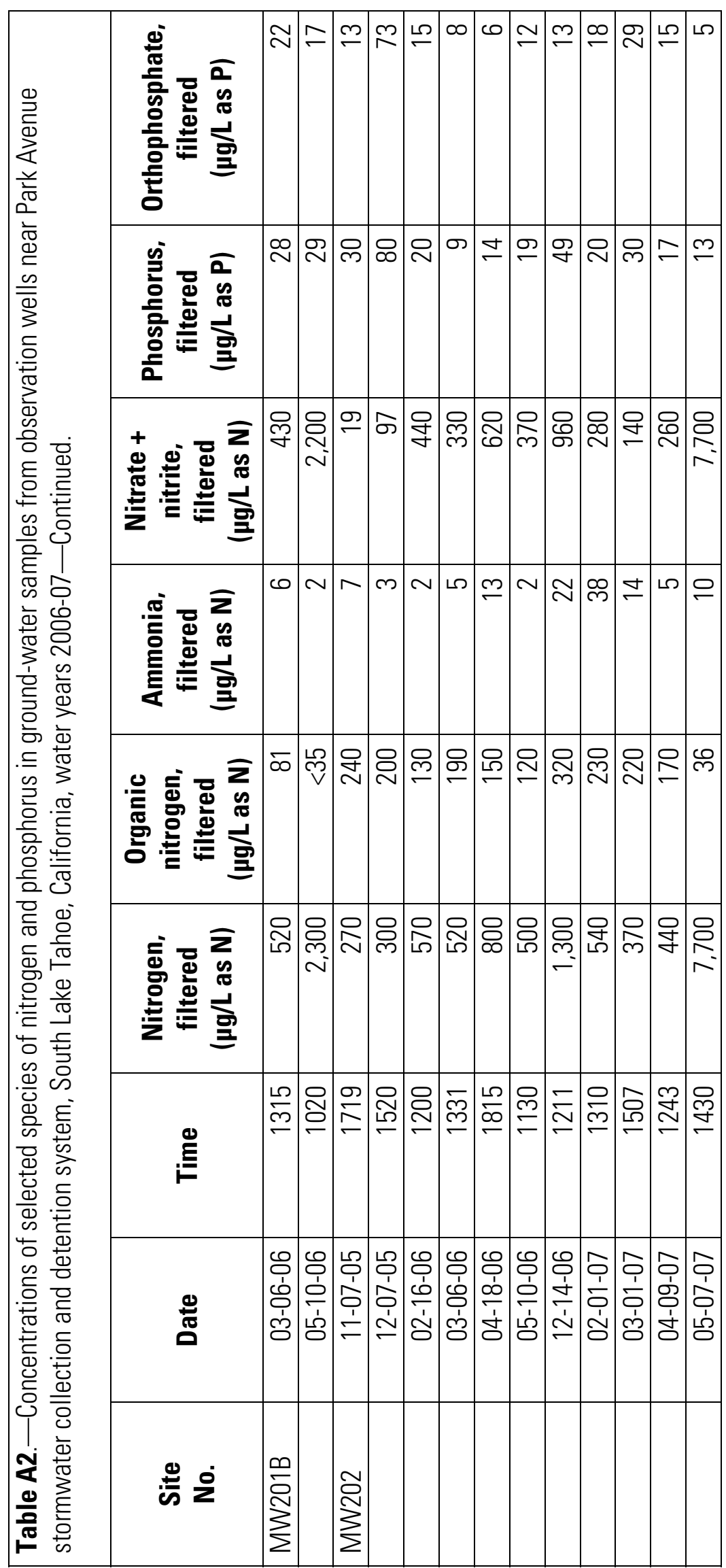




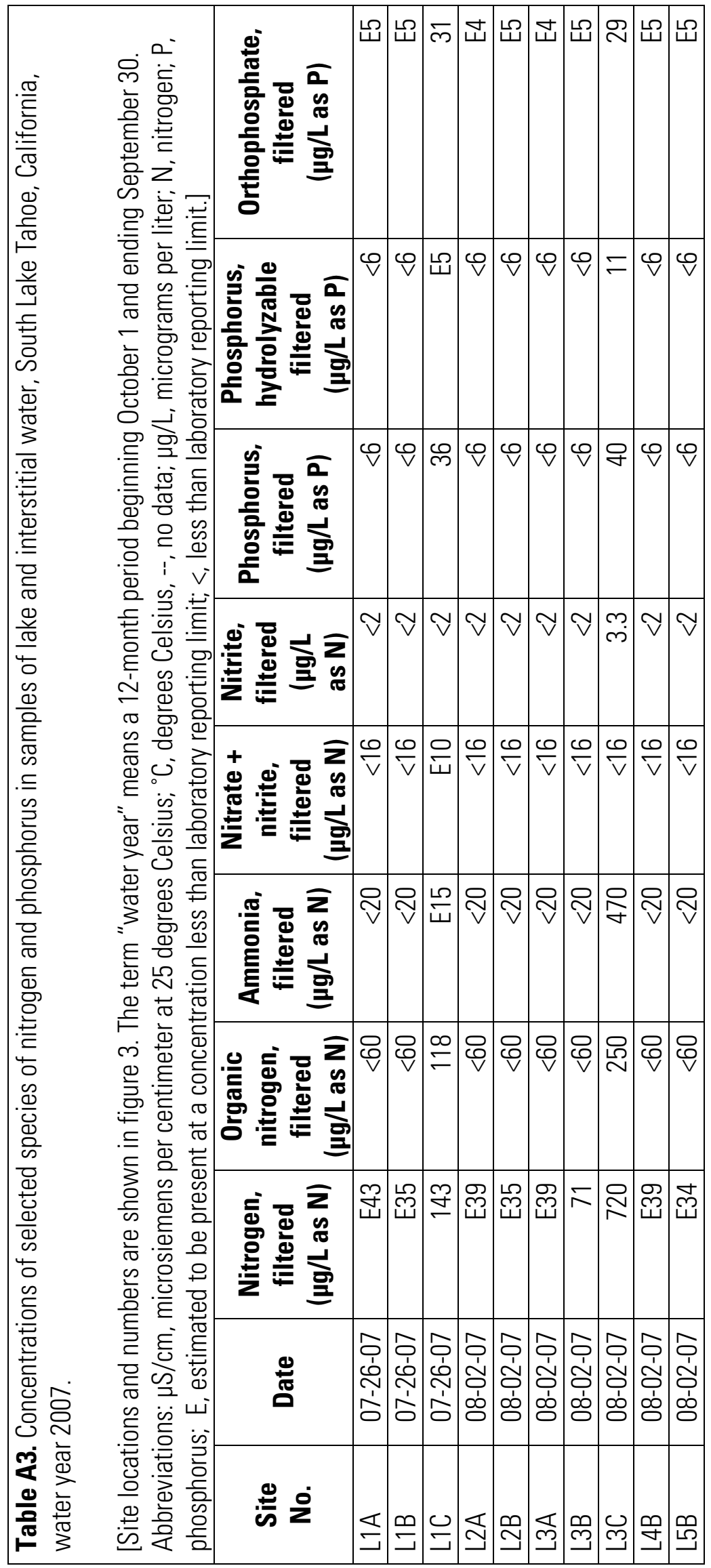




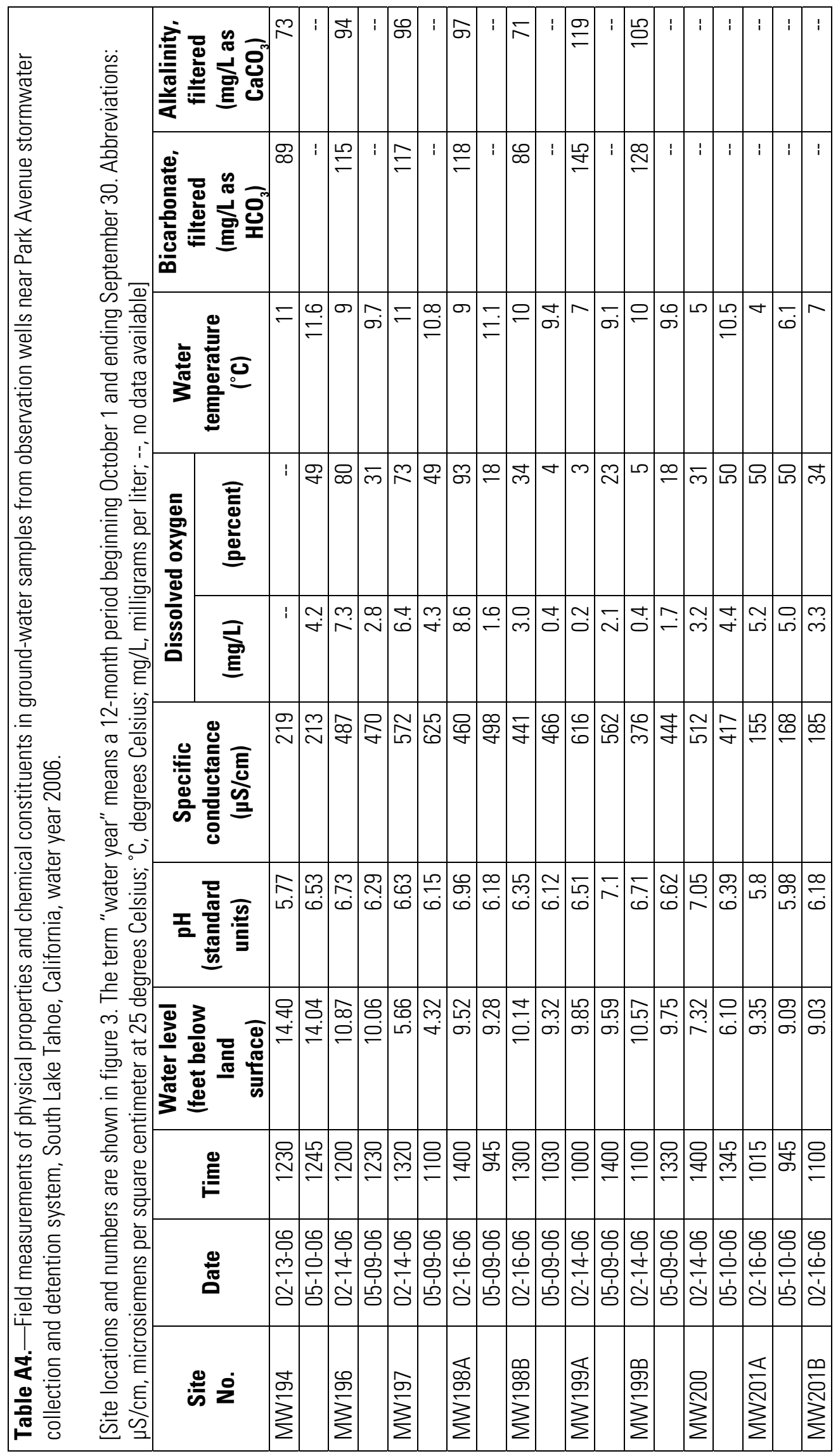




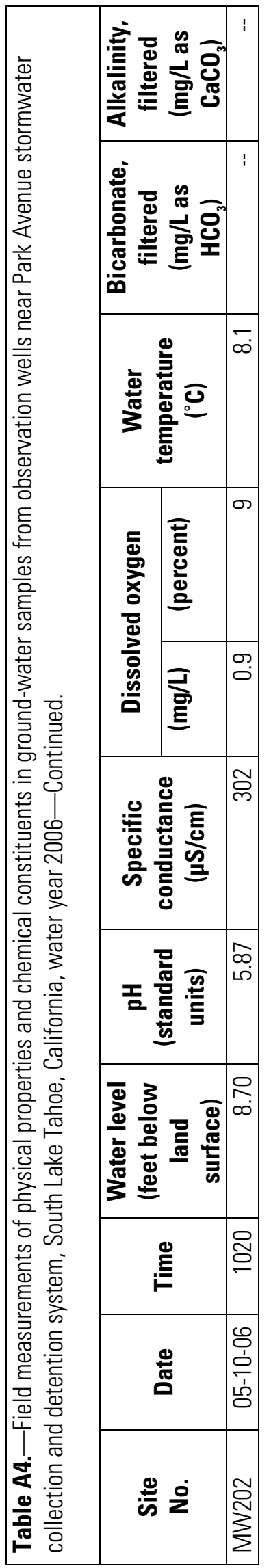

\begin{tabular}{|c|c|c|c|c|c|c|c|c|c|}
\hline \multicolumn{10}{|c|}{ 읏요 } \\
\hline 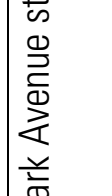 & 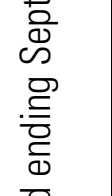 & 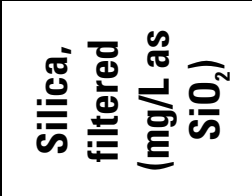 & $\frac{N}{n}$ & $\frac{0}{\operatorname{m}}$ & $\check{\sim}$ & $\begin{array}{l}0 \\
\stackrel{2}{\sim} \\
\stackrel{N}{N}\end{array}$ & $\underset{\sim}{\sim}$ & $\hat{\approx}$ & $\hat{\curvearrowright}$ \\
\hline 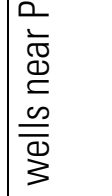 & 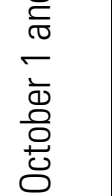 & 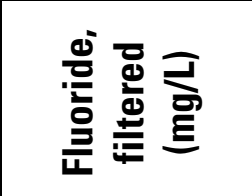 & $\dot{\vec{v}}$ & $\dot{\vec{v}}$ & $\dot{\vec{v}}$ & $\check{\nabla}$ & $\check{\dot{\sigma}}$ & $\check{\nabla}$ & $\bar{v}$ \\
\hline 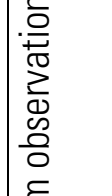 & 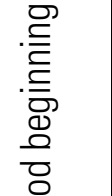 & 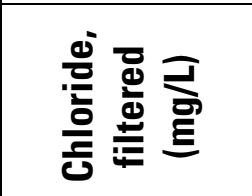 & $\begin{array}{l}\mathscr{Q} \\
\dot{\forall}\end{array}$ & 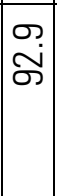 & $\stackrel{\infty}{\ominus}$ & $\begin{array}{l}\infty \\
\dot{\delta} \\
\text { o. }\end{array}$ & $\begin{array}{l}0 \\
6 \\
\infty\end{array}$ & & 范 \\
\hline$\frac{\infty}{0}$ & 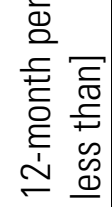 & 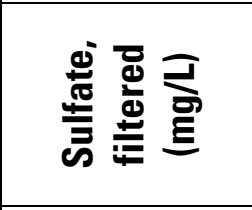 & 它 & m. & 离 & 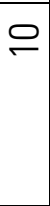 & $\begin{array}{l}0 \\
0 \\
0\end{array}$ & $\stackrel{\infty}{-}$ & فم \\
\hline 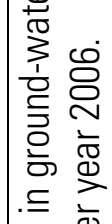 & 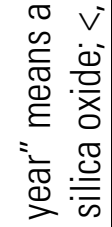 & 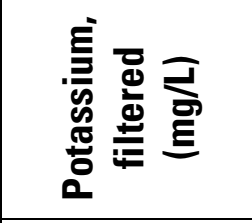 & 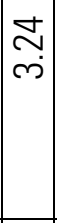 & $\begin{array}{l}\sigma \\
\\
\end{array}$ & $\left|\begin{array}{c}\bar{\tau} \\
\dot{0}\end{array}\right|$ & $\begin{array}{l}\stackrel{D}{m} \\
\dot{m}\end{array}$ & $\mid$\begin{tabular}{|}
0 \\
\\
\end{tabular} & & চ \\
\hline 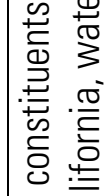 & 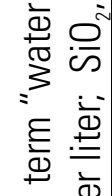 & 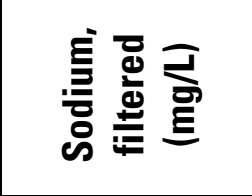 & مِ & 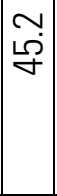 & \begin{tabular}{l}
$\sim$ \\
$\dddot{\gamma}$ \\
\multirow{\gamma}{*}{}
\end{tabular} & $\begin{array}{l}\infty \\
\infty \\
\infty\end{array}$ & $\begin{array}{l}\sigma \\
\text { లె }\end{array}$ & & مَ مَ \\
\hline 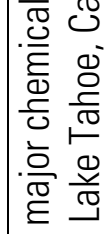 & 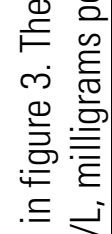 & 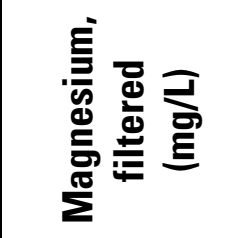 & 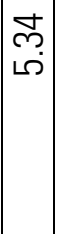 & \begin{tabular}{|l|}
$\infty$ \\
\end{tabular} & $\approx$ & $\underset{\infty}{\underset{\infty}{\sim}}$ & t. & & $\underset{\text { }}{\grave{n}}$ \\
\hline 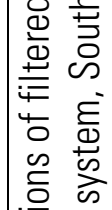 & 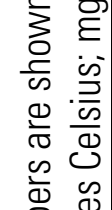 & 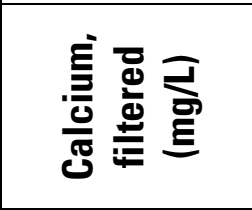 & \begin{tabular}{|l|}
0 \\
0 \\
0
\end{tabular} & $\begin{array}{c}\hat{c} \\
\dot{q}\end{array}$ & \begin{tabular}{|l}
7 \\
0 \\
0 \\
0
\end{tabular} & $\begin{array}{l}\text { o } \\
\infty \\
o\end{array}$ & $\begin{array}{l}m \\
\stackrel{n}{\sim}\end{array}$ & & $\stackrel{m}{\infty}$ \\
\hline 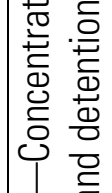 & 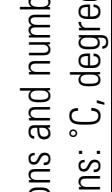 & 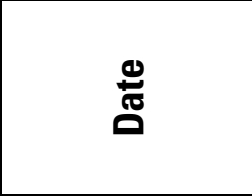 & 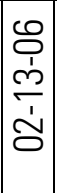 & 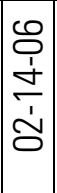 & 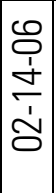 & 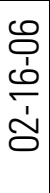 & 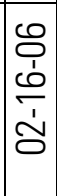 & 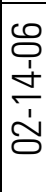 & 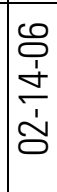 \\
\hline 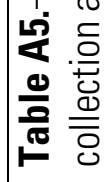 & 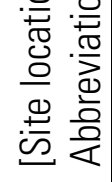 & $\stackrel{\Perp}{\dot{\omega}} \frac{0}{2}$ & 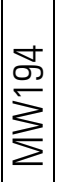 & $\sum_{\substack{\infty \\
\infty}}^{\infty}$ & $\sum_{\substack{\infty \\
\vdots}}^{\sum^{2}}$ & $\stackrel{\substack{\infty \\
\sum}}{\sum}$ & 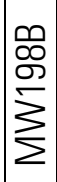 & 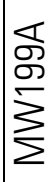 & 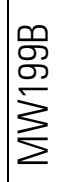 \\
\hline
\end{tabular}




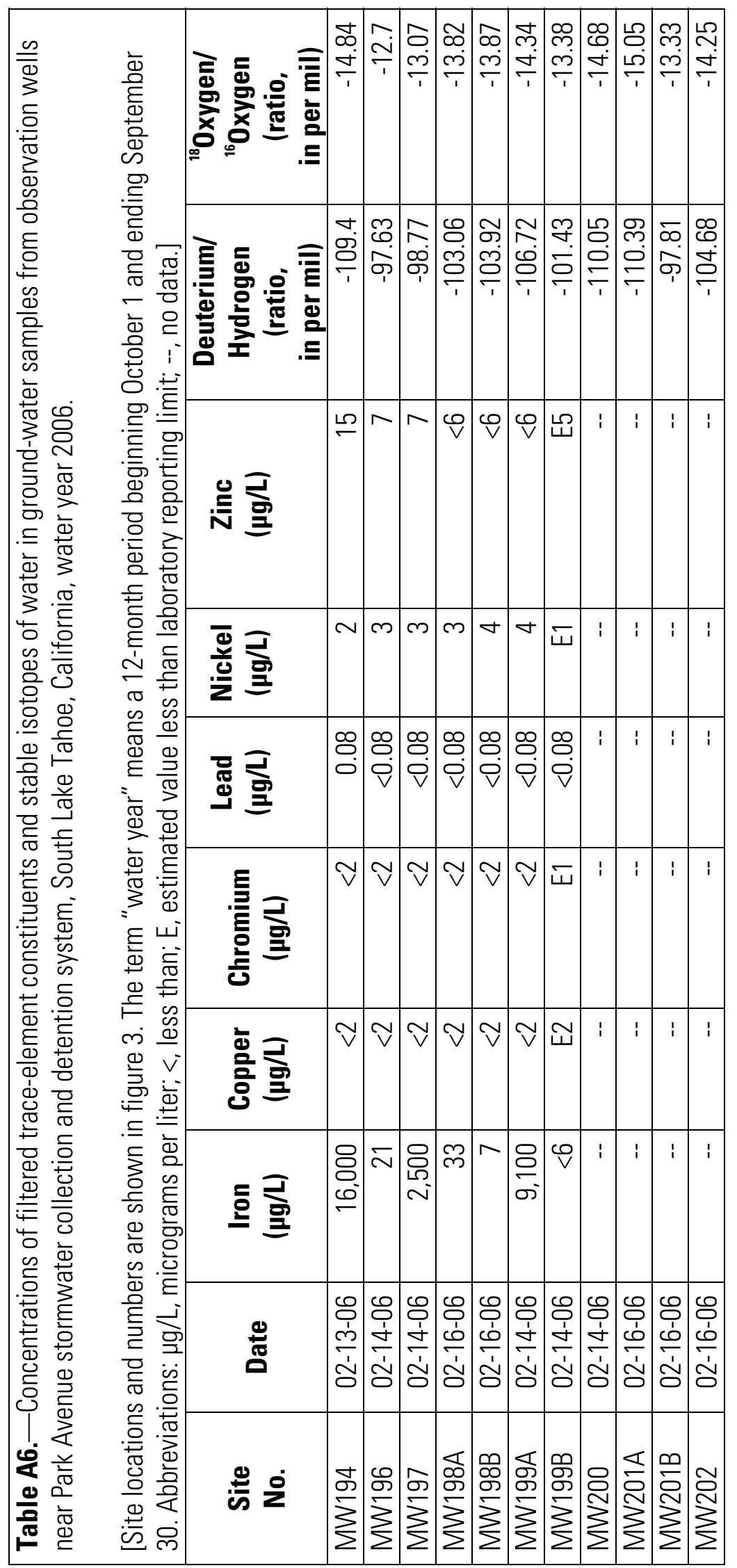




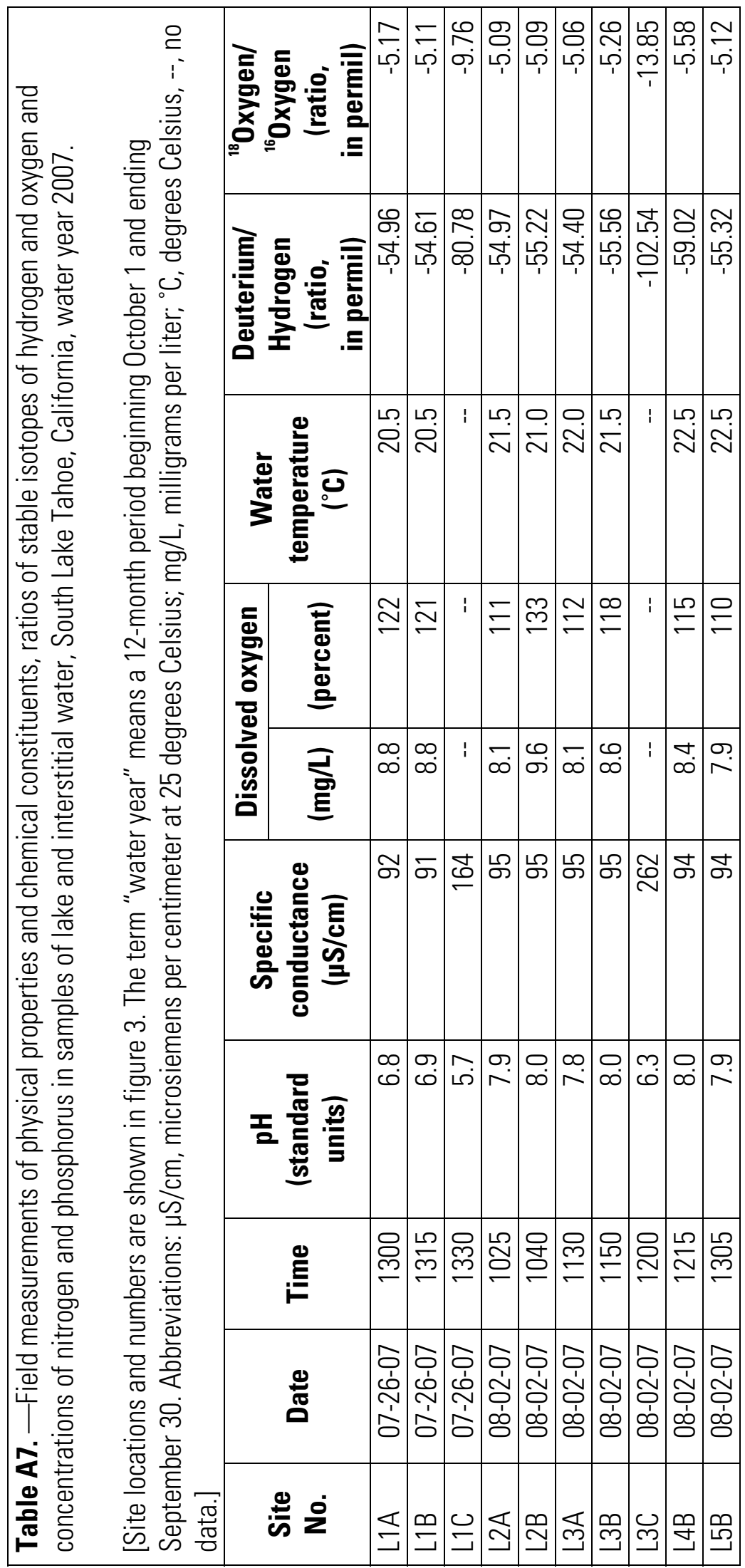


This page intentionally left blank. 
Appendix B. Bottom-Sediment Quality Data 


\begin{tabular}{|c|c|c|c|c|c|c|c|c|c|c|}
\hline 㐫 & 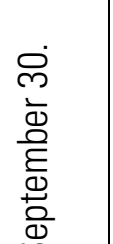 & 馬 & ఖ & வ & 흘 & $\stackrel{\curvearrowright}{\simeq}$ & $\stackrel{m}{\infty}$ & 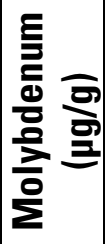 & बे & $\widetilde{0}$ \\
\hline 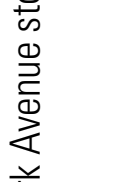 & 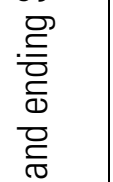 & 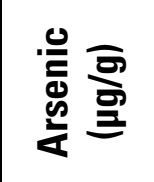 & $\stackrel{\infty}{\sim}$ & $\stackrel{\infty}{\infty}$ & 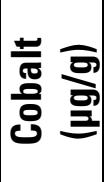 & $\approx$ & $\stackrel{\infty}{\infty}$ & 즐 & $\stackrel{\Perp}{\check{\sigma}}$ & 它 \\
\hline 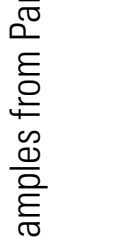 & 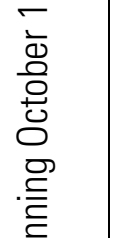 & 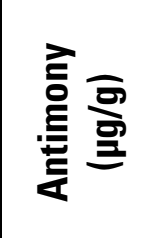 & $m$ & $\stackrel{0}{-}$ & 틀 & $\widetilde{N}$ & 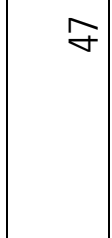 & 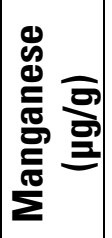 & $\begin{array}{l}8 \\
\varnothing 0\end{array}$ & $\frac{8}{20}$ \\
\hline 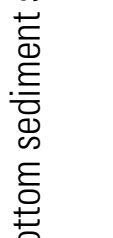 & 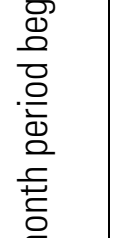 & 㤩 & $\frac{8}{\infty}$ & 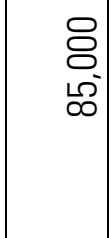 & 틀 & ִָ. & $\begin{array}{l}\infty \\
\infty \\
\infty\end{array}$ & 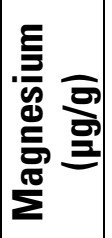 & 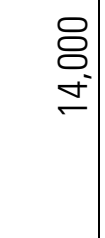 & $\begin{array}{l}\text { 8. } \\
\text { ○ }\end{array}$ \\
\hline 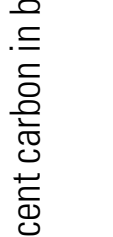 & 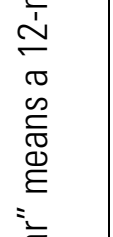 & 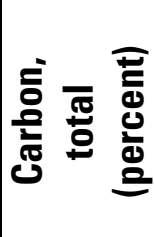 & مִ & $\stackrel{m}{-}$ & 틀 & g & ঙ্ & 틀 & ल) & 占 \\
\hline 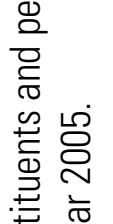 & 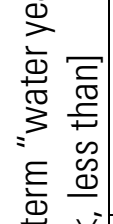 & 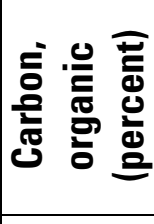 & N & 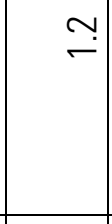 & 틀 & $\begin{array}{l}\text { ஜ } \\
\circ \\
\infty \\
\sim\end{array}$ & $\begin{array}{l}0 \\
0 \\
0 \\
0\end{array}$ & 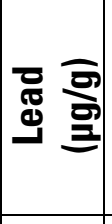 & 芯 & 므 \\
\hline 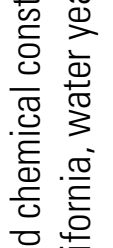 & 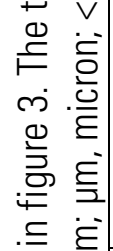 & 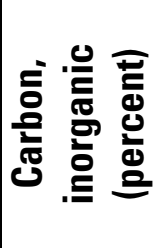 & 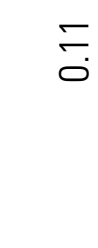 & $\begin{array}{l}\text { ఇa. } \\
0 .\end{array}$ & 틀 & Ðె. & $\underset{\sigma}{~}$ & 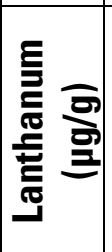 & হ & mे \\
\hline 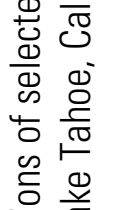 & 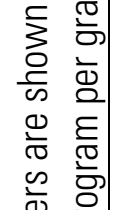 & 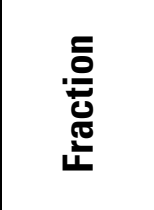 & 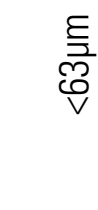 & $\begin{array}{l}\frac{E}{7} \\
\text { ले } \\
\stackrel{0}{v}\end{array}$ & 흘 & Ðీ. & ๗ి. & 은 홍 & $\begin{array}{l}\frac{8}{8} \\
\dot{1}\end{array}$ & $\begin{array}{l}\text { ᄋ } \\
\text { ○ } \\
\text { О }\end{array}$ \\
\hline 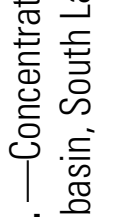 & 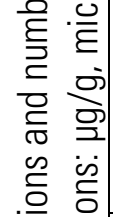 & $\stackrel{\oplus}{\stackrel{ \pm}{ \pm}}$ & $\begin{array}{l}\stackrel{0}{0} \\
\frac{1}{n} \\
0 \\
0\end{array}$ & $\begin{array}{l}\text { 이 } \\
1 \\
\dot{n} \\
0 \\
0\end{array}$ & 哥 & $\stackrel{\nabla}{-}$ & ๑ே. & 豆 & Ф) & $\approx$ \\
\hline 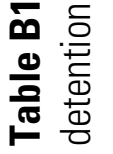 & 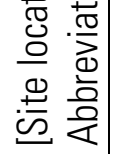 & $\stackrel{\stackrel{2}{\infty}}{\dot{c}}$ & 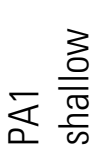 & $\begin{array}{l}\overline{\mathbb{1}} \\
\frac{0}{0}\end{array}$ & $\stackrel{\oplus}{\infty} \frac{0}{2}$ & $\overline{\frac{\partial}{\alpha}} \frac{\frac{\partial}{\bar{\sigma}}}{\frac{\sigma}{\omega}}$ & 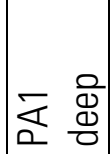 & $\stackrel{\stackrel{ \pm}{\omega}}{2}$ & $=\frac{\frac{3}{\bar{I}}}{\frac{\bar{d}}{\infty}}$ & $\begin{array}{l}\overline{4} \\
\text { 咅 }\end{array}$ \\
\hline
\end{tabular}




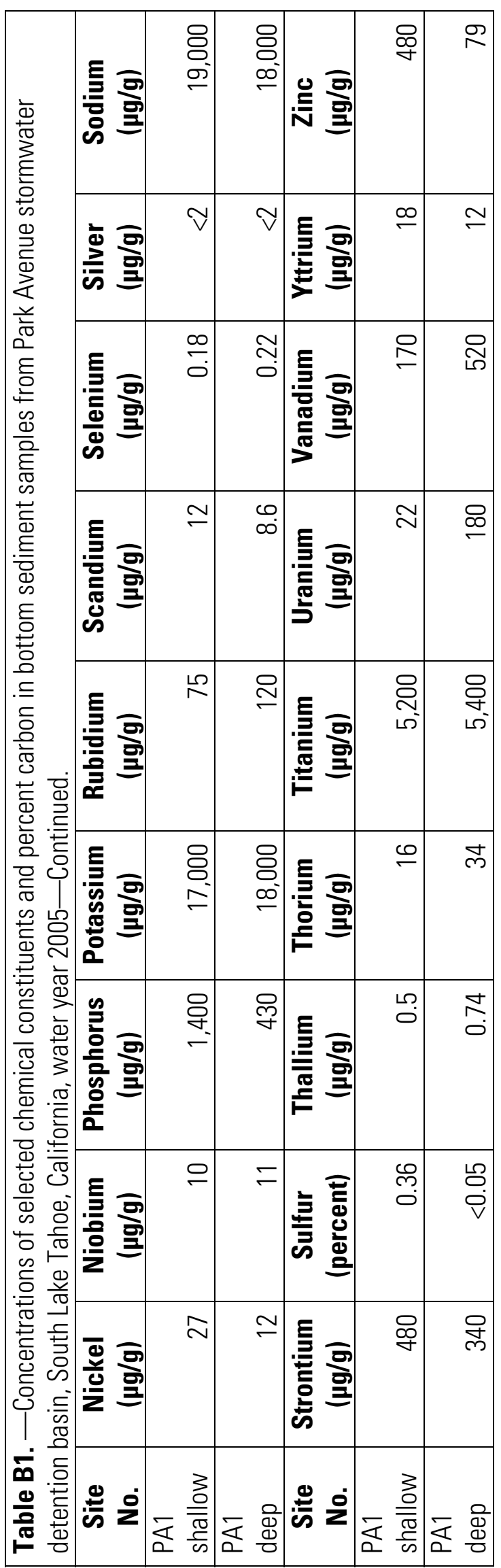




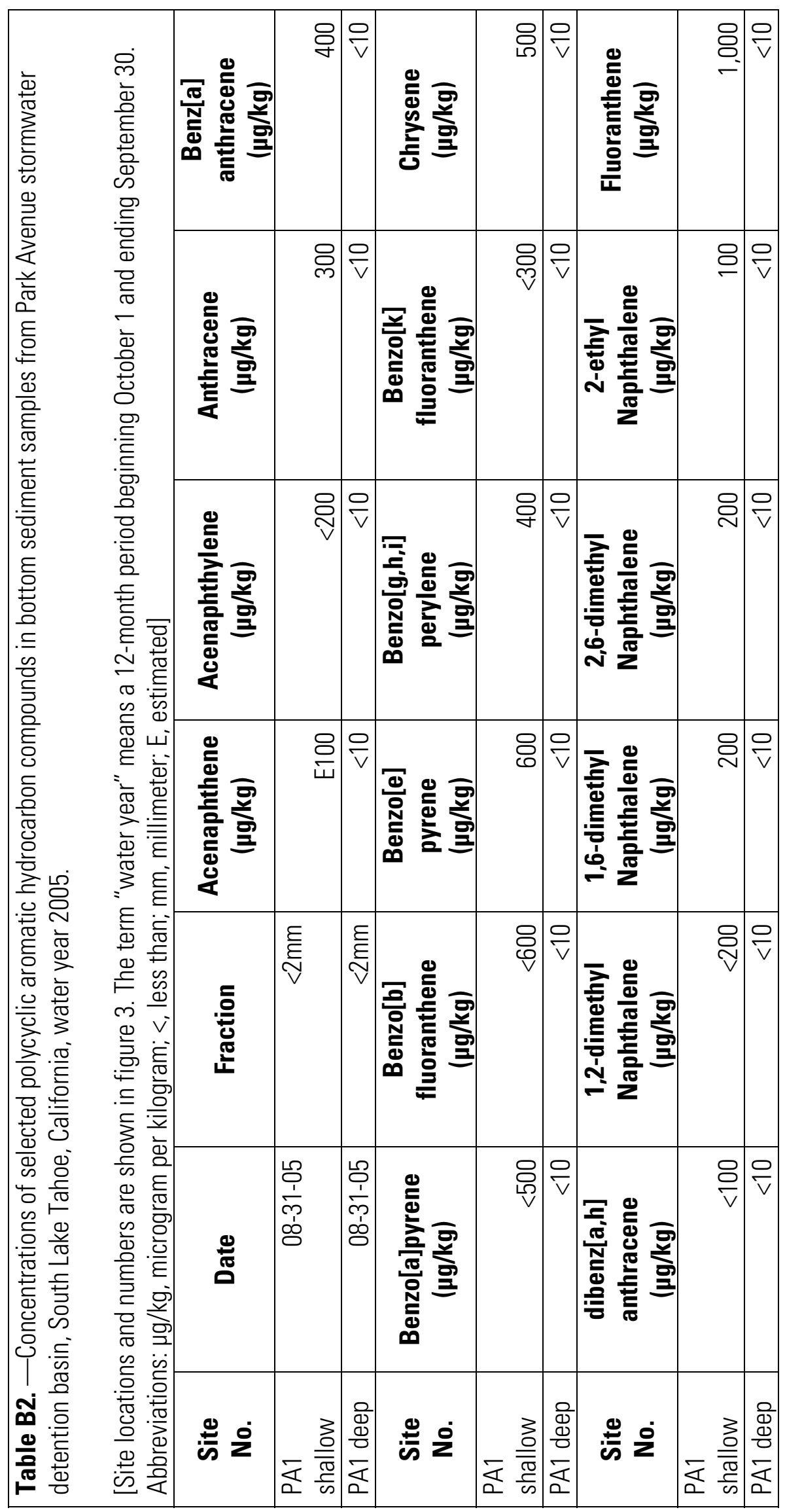




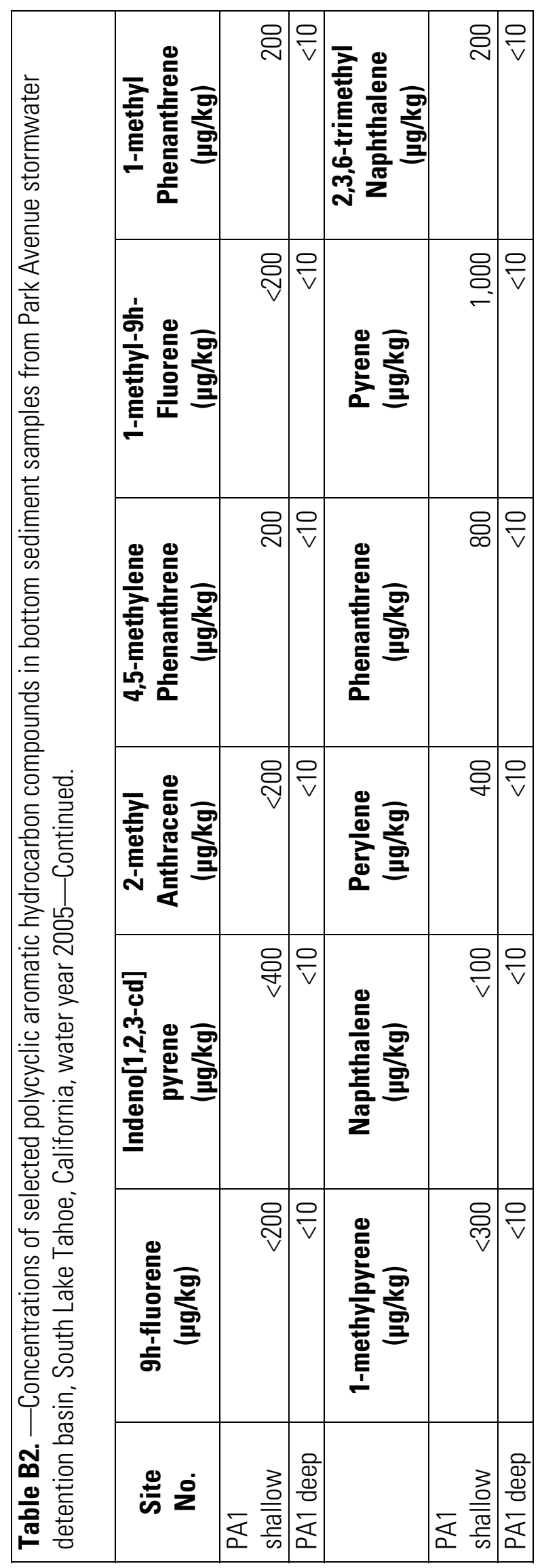


This page intentionally left blank. 
For more information concerning the research in this report, contact the Director, Nevada Water Science Center

U.S. Geological Survey

2730 N. Deer Run Road

Carson City, Nevada 89701

http://nv.water.usgs.gov 
흠

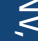

产 